Prepared for the

National Park Service

\title{
A Review and Synthesis of the Scientific Information Related to the Biology and Management of Species of Special Concern at Cape Hatteras National Seashore, North Carolina
}

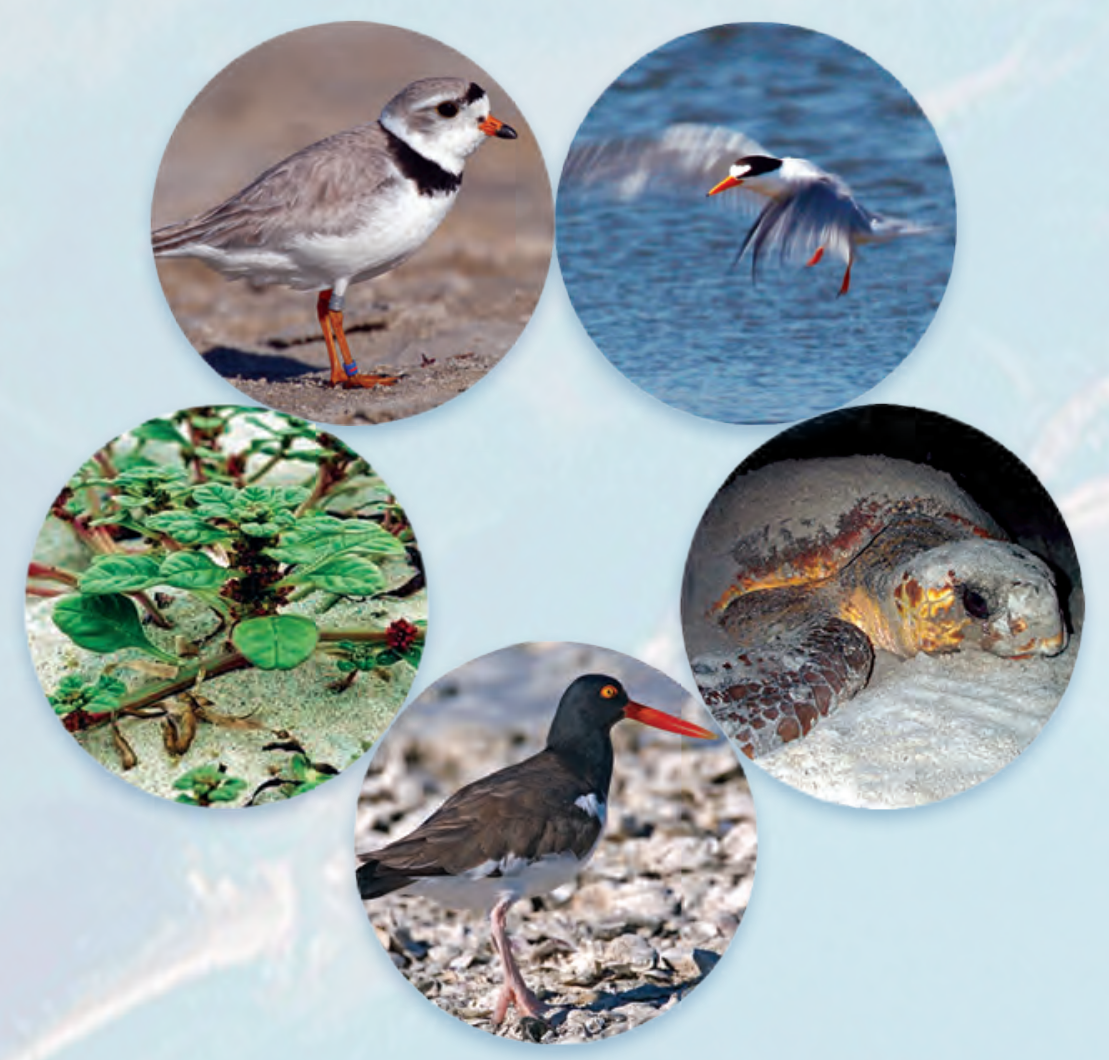

Open-File Report 2009-1262 
Cover. Clockwise: Seabeach amaranth (Amaranthus pumilus), New York Natural Heritage Program, photograph by Stephen M. Young; piping plover (Charadrius melodus), photograph by Jonathan B. Cohen; least tern (Sterna antillarum), photograph by Michael Ayers; loggerhead turtle (Caretta caretta), photograph by Matthew Godfrey; American oystercatcher (Haematopus palliates), photograph by Alan D. Wilson. Background satellite photograph of Cape Hatteras by the National Aeronautics and Space Administration (NASA), 1989. 


\section{A Review and Synthesis of the Scientific Information Related to the Biology and Management of Species of Special Concern at Cape Hatteras National Seashore, North Carolina}

Introduction and Overview

By John B. French, Jr. (USGS Patuxent Wildlife Research Center, Laurel, MD)

Chapter 1-Management and Protection Protocols for the Threatened Piper Plover on Cape Hatteras National Seashore, North Carolina

By Jonathan B. Cohen (Virginia Tech University, Blacksburg, VA)

Chapter 2-Management, Monitoring, and Protection Protocols for American Oystercatchers at Cape Hatteras National Seashore, North Carolina

By J. Michael Meyers (USGS Patuxent Wildlife Research Center, Laurel, MD)

Chapter 3-Management, Monitoring, and Protection Protocols for Colonially Nesting Waterbirds at Cape Hatteras National Seashore, North Carolina

By R. Michael Erwin (USGS Patuxent Wildlife Research Center, Laurel, MD)

Chapter 4-Management and Protection Protocols for Nesting Sea Turtles on Cape Hatteras National Seashore, North Carolina

By Jonathan B. Cohen (Virginia Tech University, Blacksburg, VA)

Chapter 5-Management, Monitoring, and Protection Protocols for Seabeach Amaranth at Cape Hatteras National Seashore, North Carolina

By Jeffrey L. Marion (USGS Patuxent Wildlife Research Center, Virginia Tech Field Unit, Blacksburg, VA)

Prepared for the

National Park Service

Open-File Report 2009-1262

U.S. Department of the Interior

U.S. Geological Survey 


\section{U.S. Department of the Interior \\ KEN SALAZAR, Secretary \\ U.S. Geological Survey \\ Marcia K. McNutt, Director}

U.S. Geological Survey, Reston, Virginia: 2010

For more information on the USGS - the Federal source for science about the Earth, its natural and living resources, natural hazards, and the environment, visit http://www.usgs.gov or call 1-888-ASK-USGS

For an overview of USGS information products, including maps, imagery, and publications, visit http://www.usgs.gov/pubprod

To order this and other USGS information products, visit http://store.usgs.gov

Any use of trade, product, or firm names is for descriptive purposes only and does not imply endorsement by the U.S. Government.

Although this report is in the public domain, permission must be secured from the individual copyright owners to reproduce any copyrighted materials contained within this report.

Suggested citation:

Cohen, J.B., Erwin, R.M., French, J.B., Jr., Marion, J.L., and Meyers, J.M., 2010, A review and synthesis of the scientific information related to the biology and management of species of special concern at Cape Hatteras National Seashore, North Carolina: U.S. Geological Survey Open-File Report 2009-1262, 100 p. 


\section{Contents}

Introduction and Overview 1

Chapter 1-Management and Protection Protocols for the Threatened Piping Plover on Cape Hatteras National Seashore, North Carolina .11

Chapter 2-Management, Monitoring, and Protection Protocols for American Oystercatchers at Cape Hatteras National Seashore, North Carolina

Chapter 3-Management, Monitoring, and Protection Protocols for Colonially Nesting Waterbirds at Cape Hatteras National Seashore, North Carolina

Chapter 4-Management and Protection Protocols for Nesting Sea Turtles on Cape Hatteras National Seashore, North Carolina

Chapter 5-Management, Monitoring, and Protection Protocols for Seabeach Amaranth at Cape Hatteras National Seashore, North Carolina.

\section{Figures}

1-1. Map showing Cape Hatteras National Seashore, North Carolina

1-2. Graph showing number of piping plover nesting pairs, Cape Hatteras National Seashore, North Carolina, 1989-2004

1-3. Diagram showing proposed exclosure designs for piping plover nests at Cape Hatteras National Seashore, (A) standard design, and (B) standard design plus 3-meter wings

1-4-1-8. Aerial photographs showing areas within which recommended closures and restrictions should occur under management options $A, B$, and $C$ at-

1-4. Hatteras Spit

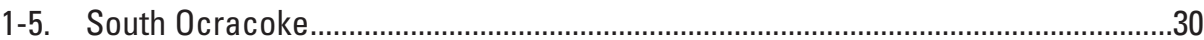

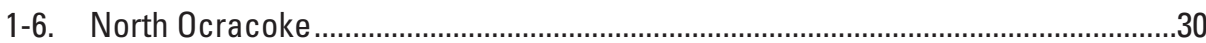

1-7. Cape Point and South Beach ...............................................................................30

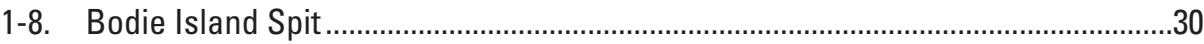

3-1. Map showing Cape Hatteras National Seashore, North Carolina ....................................62

4-1. Map showing Cape Hatteras National Seashore, North Carolina ....................................72

4-2. Graph showing number of sea turtle nests at Cape Hatteras National Seashore, North Carolina, 1995-2004 .......................................................................................... 73

5-1. Photograph showing seabeach amaranth (Amaranthus pumilus) .................................89

\section{Tables}

1-1. Median and maximum nonbreeding birds seen per daily survey during fall, winter, and spring, selected sites at Cape Hatteras National Seashore, 2000-2005

1-2. Comparison of recommendations in the Atlantic Coast piping plover revised recovery plan (1996) and this Protocol

3-1. Estimates of colonial waterbird nesting (in nesting pairs) at Cape Hatteras National Seashore from selected years, 1973 to 2003.

5-1. Numbers of naturally occurring plants of $A$. pumilus at Cape Hatteras (CAHA) and Cape Lookout (CALO) National Seashores since 1985 



\section{A Review and Synthesis of the Scientific Information Related to the Biology and Management of Species of Special Concern at Cape Hatteras National Seashore, North Carolina}

By (alphabetically) Jonathan B. Cohen, R. Michael Erwin, John B. French, Jr., Jeffrey L. Marion, and J. Michael Meyers

\section{Introduction and Overview}

By John B. French, Jr.

\section{Introduction}

The U.S. Geological Survey's Patuxent Wildlife Research Center (PWRC) conducted a study for the National Park Service (NPS) Southeast Region, Atlanta, GA, and Cape Hatteras National Seashore (CAHA) in North Carolina to review, evaluate, and summarize the available scientific information for selected species of concern at CAHA (piping plovers, sea turtles, seabeach amaranth, American oystercatchers, and colonial waterbirds). This work consisted of reviewing the scientific literature and evaluating the results of studies that examined critical life history stages of each species, and focused on the scientific findings reported that are relevant to the management of these species and their habitats at CAHA. The chapters that follow provide the results of that review separately for each species and present scientifically based options for resource management at CAHA.

Although no new original research or experimental work was conducted, this synthesis of the existing information was peer reviewed by over 15 experts with familiarity with these species. This report does not establish NPS management protocols but does highlight scientific information on the biology of these species to be considered by NPS managers who make resource management decisions at CAHA.

To ensure that the best available information is considered when assessing each species of interest at CAHA, this review included published research as well as practical experience of scientists and wildlife managers who were consulted in 2005. PWRC scientists evaluated the literature, consulted wildlife managers, and produced an initial draft that was sent to experts for scientific review. Revisions based on those comments were incorporated into the document. The final draft of the document was reviewed by NPS personnel to ensure that the description of the recent status and management of these species at CAHA was accurately represented and that the report was consistent with our work agreement. The following section summarizes the biological information relevant to resource management for the species of concern at CAHA. 


\section{Summary of Species Biology}

Piping plover The piping plover is a small (17-18 cm long, 43-63 g), sand-colored shorebird endemic to North America (Elliot-Smith and Haig, 2004). The Atlantic Coast and Great Plains populations are threatened, and the Great Lakes population is endangered per the U.S. Endangered Species Act of 1973 (Federal Register, 1985). On the Atlantic Coast, piping plovers nest in sand, gravel, or cobble substrates in backshore, dune, inter-dune blowout, overwash fan, and barrier flat zones of open or sparsely vegetated beaches (Elliot-Smith and Haig, 2004). Where beaches are wide enough, plovers nest far from the tide line to reduce risk of nest overwash; however, this places nests closer to vegetated dunes where risk of predation is high (Burger, 1987). Chicks leave the nest scrape within a few hours of hatching and never return except where a nest hatches at night (Wolcott and Wolcott, 1999).

During territory establishment and during migration and winter, foraging adults exhibit a preference for low-wave energy, moist substrate habitat (MOSH) for foraging, especially intertidal mudflats and sandflats (Fraser and others, 2005; Zonick, 2000; Cohen and others, 2008). Although chicks follow adults to foraging habitat, they forage for themselves. Foraging broods exhibit a preference for wrack and MOSH, including mudflats, sandflats, and ephemeral pools (Goldin, 1993; Hoopes, 1993; Kuklinski and others, 1996; Elias and others, 2000; Cohen and others, 2009).

Direct threats to reproduction include flooding by tides or storms, mammalian and avian predators, ghost crabs, and crushing of eggs or chicks due to human recreation (Patterson and others, 1991; Melvin and others, 1994; Watts and Bradshaw, 1995; Loegering, 1995; Murphy and others, 2003; Cohen and others, 2009). Reproductive failure due to predation has led to abandonment of territories within and between breeding seasons on Long Island, specifically when population-level reproduction was poor (Cohen and others, 2006). The impact of predation can be greater on beaches with high human use (Strauss, 1990), presumably because the presence of pets and trash that may attract wild predators accompanies the presence of humans (USFWS, 1996). In some studies, beaches with high levels of human disturbance had lower reproductive rates than less-disturbed beaches (Cairns, 1982; Flemming and others, 1988). At other sites, disturbance did not affect reproductive rate (Patterson and others, 1991; Hoopes, 1993; Burger, 1994), although pedestrians, kites, and off-road vehicles (ORVs) caused a decrease in brood foraging behavior in Massachusetts (Hoopes, 1993) and New Jersey (Burger, 1994). ORV use has been demonstrated to destroy the wrack line (Goldin, 1993), thereby degrading an important foraging habitat. Breeding and non-breeding birds are subject to disturbance (disruption of normal activities) by ORVs and pedestrians (Goldin, 1993).

Beach "renourishment" and artificial dune construction to protect human structures from storm damage may temporarily increase the size of nesting areas (Melvin and others, 1991; Cohen and others, 2009). However, "renourishment" projects alter the profile of beaches, causing increased erosion and habitat loss over longer periods (Leatherman and Allen, 1985). Furthermore, beach stabilization prevents normal storm processes, such as overwash fan formation, thereby leading to long-term loss of MOSH and accelerated vegetative succession in areas of potential nesting habitat (Dolan and others, 1973). Beach "renourishment" often is followed by human development, and construction of human structures on beaches eliminates breeding territories and may result in an increased level of human disturbance of, and predation on, remaining pairs (Cohen and others, 2009).

Sources of mortality during migration and winter have not been quantified, and overwinter survival has been as high as 100 percent (Drake and others, 2001; Cohen and others, 2008), although avoidance of highhuman disturbance areas has been documented (Zonick, 2000; Drake and others, 2001). Since wintering populations have been shown to prefer areas around inlets (Nicholls and Baldassarre, 1990), artificial closure of storm-created inlets may reduce local carrying capacity for non-breeding birds.

American oystercatcher American oystercatchers (Haematopus palliates) usually build nests near or on the beach by scraping many shallow depressions in the sand (4-6 $\mathrm{cm}$ deep and $20 \mathrm{~cm}$ in diameter). Oystercatchers also build nests on sand and shell flats, marsh islands, and dredge spoil islands (Nol and Humphrey, 1994; McGowan and others, 2005). In North Carolina, nests are rarely more than 21 to $32 \mathrm{~m}$ from water (Lauro and Burger, 1989; Nol and Humphrey, 1994) and are often on a mound, which serves as a lookout for the birds (Baicich and Harrison, 1997). Primarily monogamous, American oystercatchers may mate for life although few long-term records exist (Palmer, 1967; Nol and Humphrey, 1994). 
American oystercatchers require a period of 90 to 140 days to reproduce beginning in late March and early April in North Carolina. During that period, nesting birds will react to anything within about 200 to 300 $\mathrm{m}$ from their nests or young. Disturbing the birds (within $150 \mathrm{~m}$ ) reduces incubation of eggs and foraging for young during the nestling stage (Verboven and others, 2001; Sabine, 2005). Both sexes incubate three-egg (rarely two and four) clutches for 24 to 28 days. Incubation may begin after laying the second egg (Nol and Humphrey, 1994) or invariably after the last egg (Baicich and Harrison, 1997). Pairs will re-nest if the eggs or nestlings are lost early in the season, but clutch sizes are rarely more than two eggs. Precocial and downy nestlings remain in the nest for 1 to 2 days and then move with adults within the nesting territory or into adjacent feeding areas, which can be 50 to $200 \mathrm{~m}$ away, depending on the local landscape; for example, breeding birds may move off the nesting territory to a marsh area inland from beaches to feed the young. Nestlings will crouch motionless when alarmed, which makes them difficult to see. They fledge in about 35 days. Fledglings depend on adults almost entirely until 60 days old (Palmer, 1967; Nol and Humphrey, 1994).

Major causes of known nest failures ( $<49 \%$ of nesting attempts) are mammalian predation $(60 \%)$, overwash $(25 \%)$, avian predation (5\%), abandonment (5\%, possibly another cause), humans $(3 \%)$, vehicles $(<2 \%)$, and ghost crabs $(<2 \%)$ (Simons and others, 2004). Sabine (2005) found strong associations between significantly reduced oystercatcher reproductive success and high predation or high levels of human disturbances on Cumberland Island National Seashore. Others have found reduced foraging by European oystercatchers in areas disturbed by humans (Verhulst and others, 2001). In other countries similar relationships have been found (to quote Sabine, 2005): "Human activities reduced reproductive success and influenced geographical distribution of African black oystercatchers (H. moquini) in South Africa" (Jeffery, 1987; Leseberg and others, 2000). Threats to nesting American oystercatchers on CAHA are numerous and inter-related, but more than 51 percent of nest losses are from undetermined causes, which does not allow managers to correct the problem (Simons and others, 2004).

The scientific literature indicates that excluding human activity, in varying levels, from nesting areas, as well as managing ORVs on the beach and occasionally predator management, may reduce chick mortality. Mortality of eight oystercatcher chicks, some marked with radios transmitters, was documented over the last 2 years in North Carolina and was caused by ORVs crushing them on the beach (Simons and others, 2004).

Colonial waterbirds Colonial waterbirds, by definition, nest in concentrations ranging from a few nests to several thousand, depending upon the species in question. On Cape Hatteras National Seashore and the islands adjacent, the key species include the least tern, common tern, gull-billed tern, royal tern, sandwich tern, and black skimmer. Other colonial waterbirds of less management concern include gulls (herring, laughing, great black-backed), brown pelicans, and double-crested cormorants. Most of these species nest in mixedspecies colonies, with the most common associations being the common tern-gull-billed tern-black skimmer group and the royal tern-sandwich tern association (Parnell and Soots, 1979).

Of the key species listed above, all prefer to nest in early successional habitats, often wash-over areas along barrier islands, or near inlets with high wave energy. Least terns often nest in small single-species colonies, from 10 to 150 nests on open sand or shell flats (Thompson and others, 1997). Similarly, black skimmers (Gochfeld and Burger, 1994), common terns (Nisbet, 2002), and gull-billed terns (Parnell and others, 1995) often nest together in associations of up to several hundred nests, usually near inlets or on sparsely vegetated sand flats or near the base of dunes.

Most of the key species nesting in North Carolina arrive in late April to early May with the majority of egg laying and chick rearing ranging from mid-May to August (Buckley and Buckley, 1976). The latter period may extend into September (especially black skimmers and common terns) if renesting occurs due to early nest failures. This period coincides with the period of high human recreational use of the beaches in North Carolina and along the Atlantic Coast.

Upon hatching, young terns and skimmers remain near the colony usually for at least a week, but once they are large and more mobile, they often travel considerable distances over the next 3 to 4 weeks (until they can fly), especially if disturbed by human pedestrians, vehicles, dogs, or other interferences (Buckley and Buckley, 1976; Thompson and others, 1997).

The potential for waterbird-human interactions has stimulated much research to determine buffer distances for various waterbird species during the nesting season as one way to minimize the effects of human disturbance (Erwin, 1989). The set of distance guidelines pertain only to colonies in early stages, however, not post-hatching stages. Where young are dispersing from nesting colonies, the area requiring protection becomes significantly larger in order to reduce the potential mortality caused by waterbird-human interactions. 
Sea turtles Sea turtles spend greater than 99 percent of their lives at sea annually, returning to land only to lay their nests from late spring to late summer. The loggerhead turtle (Caretta caretta) is by far the most numerous sea turtle to nest at Cape Hatteras National Seashore, comprising 95 percent of the nesting record. Green turtles (Chelonia mydas) and leatherbacks (Dermochelys coriacea) have nested sporadically at CAHA (Altman and Lyons, National Park Service, written commun., 2003). CAHA is the northernmost nesting site for leatherbacks on the Atlantic Coast (Rabon and others, 2003). Loggerhead turtles were listed as federally threatened in the United States in 1978 (NMFS and USFWS, 1991a), and the other two species were listed as endangered in 1978 (NMFS and USFWS, 1991b) and 1970 (NMFS and USFWS, 1992), respectively.

Gravid females emerge from the swash zone, typically at night, and crawl toward the dune line until they encounter a suitable nest site, typically on open sand at the seaward base of a dune, but sometimes in vegetation. Individual females may nest one to six times per nesting season at intervals of 12 to 16 days during the late spring to late summer (Miller and others, 2003). Newly emerged hatchlings immediately head for the sea, most likely orienting toward the water by moving toward the brightest horizon and away from dark silhouettes (Lohmann and Lohmann, 2003).

The literature identifies many habitat-related threats to successful nesting of sea turtles. Storm events may destroy nests by flooding or piling of eroded sand on the nest site. Beach erosion due to wave action may decrease the availability of suitable nesting habitat (Steinetz and others, 1998), which leads to a decline in nesting rate. The rate of habitat loss due to natural erosion and escarpment formation may be increased when humans attempt to stabilize the shoreline, either through "renourishment" (Dolan and others, 1973) or placement of hard structures, such as sea walls or pilings (Bouchard and others, 1998). ORV traffic may alter the beach profile, leading to steeper foredunes (Anders and Leatherman, 1987), which may be unsuitable for nesting. Improperly placed erosion-control structures such as drift-fencing can act as a barrier to nesting females. Beach development may also introduce exotic vegetation which can overrun nesting habitat or make the substrate unsuitable for digging nest cavities.

The physical presence of pedestrians can disturb nesting females and prevent laying (NMFS and USFWS, 1991a,b), and anthropogenic sources of light have been shown to alter sea turtle behavior. Light from flashlights and campfires may interfere with sea-finding behavior by hatchlings; beach driving by off-road vehicles may harm sea turtles by running over nests, which may increase sand compaction and decrease hatching success or kill pre-emergent hatchlings (NMFS and USFWS, 1991a,b). Beach driving can interfere with seafinding behavior if headlights are used at night and can disturb adult females and cause them to abort nesting attempts (NMFS and USFWS, 1991a,b). Artificial lighting on human structures may affect turtle behavior in a similar manner (Witherington and Martin, 1996). When artificial lighting impairs sea-finding behavior of nesting females and emerging hatchlings, the affected animals face increased exposure to the elements and predation.

Beach driving poses a risk of injury to laying females and stranded sea turtles and can leave ruts that trap hatchlings attempting to reach the ocean (Hosier and others, 1981). Pedestrians, ORV traffic, and beach-cleaning activities can directly destroy nests and can create ruts that trap emerging hatchlings and prevent them from finding the sea (Hosier and others, 1981). Trampling can increase sand compaction that may damage nests or hatchlings (Kudo and others, 2003). An increased human presence overall may lead to an increase in the presence of domestic pets that can prey upon nests and an increase in litter that may attract wild predators (National Research Council, 1990). Predation by mammals, birds, and ghost crabs may eliminate 100 percent of productivity on beaches where it is not managed (National Research Council, 1990).

Seabeach amaranth The seabeach amaranth (Amaranthus pumilus) is an annual plant, federally listed as threatened, that is native to the beaches of the Atlantic Coast. The population of this species within North Carolina has been reduced from around 40,000 plants in the late 1980s and in 1995 to 5 to 10,000 plants in 2002-03 (USFWS, 2005). Within Cape Hatteras National Seashore plant numbers declined from 3 to 15,000 plants per year found in 1987-90 to 50 to 133 plants found in 2001-03 (Jolls and others, 2004). Shoreline sands and offshore sediments provide the seed bank for this species, with germination occurring from April to July. Seeds survive many years in buried sands, germinating only when brought to the surface under the appropriate environmental conditions. Germination and growth are largely restricted to dynamic coastal overwash flats, the accreting ends of the islands, lower foredunes, and on ocean beaches above mean high tide (Weakley and Bucher, 1991). The plants are generally restricted to a narrow band of beach ranging from 0.77 to $2.00 \mathrm{~m}$ above mean high water in areas not experiencing erosion or overwash (Jolls and others, 2004). 
In addition to these narrow environmental conditions, the plant is intolerant of competition with other plants: it does not occur on well-vegetated sites. The plant is also threatened by intensive recreational vehicle or foot traffic, which can easily crush the plant's brittle, fleshy stems (U.S. Fish and Wildlife Service, 1993). The pass of even a single vehicle can crush the plant, causing mortality or reduced seed production (U.S. Fish and Wildlife Service, 1996). Off-season (December to March) traffic is more permissible: traffic that prevents widespread establishment of perennial plants is beneficial, though heavy vehicle traffic could pulverize or bury seeds below germination depths (USFWS, 1996). Pedestrian traffic, unless intensive, generally appears to have little effect on populations of seabeach amaranth.

\section{Development of Options for Management Action}

The management of endangered and threatened species is most effective when it is based on the best available information, including published research, reports, and the practical experience of scientists and wildlife managers. All of these sources were consulted and form the basis of the management options developed in this document. Each of the focal species in question is state or federally listed, or a "Species of Special Concern," and as for all such species, an important goal of management is to increase populations and thus contribute to the recovery of these species overall.

Three management options for these protected species at CAHA are presented below in order from the most to least protective. These options are intended to protect the habitats used by each species at CAHA in the recent past (that is 2000-09), where this can be determined. All three options include some degree of exclusion of recreation from a buffer zone around nests and from important habitat types entirely, restriction of recreational activities that might cross into protected zones, and removal or exclusion of predators where needed.

- Under Option A, no recreation is permitted in any habitat used in the previous 10 years by the species in question. This eliminates the threat of direct mortality or disturbance due to recreation and greatly reduces indirect impacts, such as attraction of wild predators to the habitat of protected species and alteration of the beach profile by ORV traffic.

- Under Option B, for birds and plants, pedestrian recreation, but not ORV traffic, is permitted within a corridor in historically used habitat. For sea turtles, Option B closes all historically used habitats to night use by ORVs and optionally pedestrians, and closes segments of the habitat to all recreation. Option B reduces the risk of direct mortality and disturbance over current management practices but does not reduce indirect effects of recreation to the same extent as Option A.

- Under Option C, for birds and plants, ORV and pedestrian use is permitted in a corridor in historically used habitat. For sea turtles, night use of the habitat for recreation is permitted only in conjunction with user educational programs, and as in Option B, certain segments of beach remain closed. The risk of mortality, disturbance, and indirect effects of recreation are higher than under Option A or B, but still less than under current management practices.

\section{Applying Scientific Information to Management and Recovery Goals}

The scientific literature provides the foundation for understanding and managing plant and animal species in different geographic locations and ecological settings. Published research may provide only part of the information needed for effective management of species in a particular locality. This can be particularly true for endangered and threatened species due to their low numbers or other factors that contribute to the difficulties of acquiring both quantitative and qualitative data. Hence, a sensible approach is to incorporate a program of monitoring into the management program itself. The data collected through monitoring form the basis for evaluating the effects of current management practices and making changes to those practices if needed. 
This report indicates where continued data acquisition and analysis through monitoring or local research efforts can enhance the efficacy of species or habitat management practices. Reviewing management practices may be formalized into an Adaptive Management process, where relevant, local data collected at CAHA would form the basis for the evaluation of the effects of current practices and for making changes to those practices when appropriate. Periodic reviews may be particularly appropriate for CAHA, where the dynamic nature of the beaches and inlets can markedly alter the quantity and quality of critical habitats. The following chapters present opportunities for focused monitoring or research that may be useful in evaluating resource management for each species individually, along with scientifically based options for management of each species.

\section{Acknowledgments}

Funding for this work was provided by the National Park Service to the U.S. Geological Survey, Patuxent Wildlife Research Center.

\section{Selected References}

Anders, F., and Leatherman, S., 1987, Disturbance of beach sediment by off-road vehicles: Environmental Geology and Water Sciences, no. 9, p. 183-189.

Baicich, P.J., and Harrison, C.J.O., 1997, A guide to the nests, eggs, and nestlings of North American birds (2d ed.): New York, Academic Press, 416 p.

Bouchard, S., Moran, K., Tiwari, M., Wood, D., Bolten, A., Eliazar, P., and Bjorndal, K., 1998, Effects of exposed pilings on sea turtle nesting activity at Melbourne Beach, Florida: Journal of Coastal Research, v. 14 , no. 4 , p. $1343-1347$.

Buckley, P.A., and Buckley, F.G., 1976, Guidelines for the protection and management of colonially nesting waterbirds: Boston, MA, National Park Serivice, 54 p.

Burger, J., 1987, Physical and social determinants of nest site selection in piping plover in New Jersey: Condor, no. 98, p. 811-818.

Burger, J., 1994, The effect of human disturbance on foraging behavior and habitat use in piping plover (Charadrius melodus): Estuaries, no. 17, p. 695-701.

Cairns, W.E., 1982, Biology and behavior of breeding Piping Plovers: Wilson Bulletin, no. 94, p. 531-545.

Cohen, J.B., Fraser, J.D., and Catlin, D.H., 2006, Survival and site fidelity of Piping Plovers on Long Island, New York: Journal of Field Ornithology, no. 77, p. 409-417.

Cohen, J.B., Karpanty, S.M., Catlin, D.H., Fraser, J.D., and Fischer, R.A., 2008, Winter ecology of Piping Plovers at Oregon Inlet, North Carolina: Waterbirds, no. 31, p. 472-479.

Cohen, J.B., Houghton, L.M., and Fraser, J.D., 2009, Nesting density and reproductive success of piping plovers in response to storm- and human-created habitat changes: Wildlife Monographs, no. 173, p. 1-24.

Dolan, R., Godfrey, P.J., and Odum, W.E., 1973, Man's impact on the barrier islands of North Carolina: American Scientist, no. 61, p. 152-162.

Drake, K.R., Thompson, J.E., and Drake, K.L., 2001, Movement, habitat use, and survival of nonbreeding piping plovers: Condor, no. 103, p. 259-267. 
Elias, S.P., Fraser, J.D., and Buckley, P.A., 2000, Piping plover brood foraging ecology on New York barrier island ecology: Journal of Wildlife Management, no. 64, p. 346-354.

Elliott-Smith, E., and Haig, S.M., 2004, Piping Plover Charadrius melodus, in Poole, A., ed., The Birds of North America Online: Ithaca, NY, Cornell Laboratory of Ornithology, accessed January 29, 2010 at http://bna.birds.cornell.edu/bna/species/002/articles/introduction.

Erwin, R.M., 1989, Responses to human intruders by birds nesting in colonies: experimental results and management guidelines: Colonial Waterbirds, v. 12, p. 104-108.

Federal Register, 1985, Endangered and threatened wildlife and plants; determination of endangered and threatened status for the Piping Plover; final rule: Federal Register 50:50, p. FR 50726-50734.

Flemming, S.P., Chiasson, R.D., Smith, P.C., Austin-Smith, P.J., and Bancroft, R.P., 1988, Piping plover status in Nova Scotia related to its reproductive and behavioral responses to human disturbance: Journal of Field Ornithology, no. 59, p. 321-330.

Fraser, J.D., Keane, S.E., and Buckley, P.A., 2005, Prenesting use of intertidal habitats by Piping Plovers on south Monomoy Island, Massachusetts: Journal of Wildlife Management, v. 69, no., 4, p. 1,731-1,736.

Gochfeld, M.G., and Burger, J., 1994, Black skimmer (Rynchops niger), in Poole, A., and Gill, F., eds., The birds of North America, No. 108: The Academy of Natural Sciences, Philadelphia, Pennsylvania, and American Ornithologists' Union, Washington, D.C., accessed December 10, 2009, at http://bna.birds. cornell.edu/bna/species/108/articles/introduction.

Goldin, M.R., 1993, Effects of human disturbance and off-road vehicles on piping plover reproductive success and behavior at Breezy Point, Gateway National Recreation Area, New York: Amherst, Massachusetts, University of Massachusetts, unpublished M.S. thesis, $106 \mathrm{p}$.

Hoopes, E.M., 1993, Relationships between human recreation and piping plover foraging ecology and chick survival: Amherst, Massachusetts, University of Massachusetts, unpublished M.S. thesis, 106 p.

Hosier, P.E., Kochhar, M., and Thayer, V., 1981, Off-road vehicle and pedestrial track effects on the seaapproach of hatchling loggerhead turtles: Environmental Conservation, no. 8, p. 158-161.

Jeffery, R.G., 1987, Influence of human disturbance on the nesting success of African black oystercatchers: South African Journal of Wildlife Research, no. 17, p. 71-72.

Jolls, C.L., Sellars, J.D., and Wigent, C.A., 2004, Restore Seabeach Amaranth; A federally threatened species; habitat assessment and restoration of Amaranthus pumilus, (Amaranthaceae) using remote sensing data: 2001 Natural Resource Presentation Program, RMP Project Statement CAHA-N-018.000, National Park Service, Final Report, 144 p.

Kudo, H., Murakami, A., and Watanbe, S., 2003, Effects of sand hardness and human beach use on emergence success of loggerhead sea turtles on Yakushima Island, Japan: Chelonian Conservation and Biology, no. 4, p. 695-696.

Kuklinski, M.L., Houghton, L.M., and Fraser, J.D., 1996, Piping plover breeding ecology on Cape Hatteras National Seashore with special reference to the effect of temperature on productivity: Blacksburg, Virginia, Virginia Technical University, Department of Fisheries and Wildlife Sciences, 71 p.

Lauro, B., and Burger, J., 1989, Nest-site selection of American Oystercatcher (Haematopus palliates) in salt marshes: Auk, no., 106, p. 185-192.

Leatherman, S.P., and Allen, J.R., eds., 1985, Geomorphic analysis, Fire Island Inlet to Montauk Point, Long Island, New York: Reformulation study submitted to the U.S. Army Corps of Engineers, New York District, $351 \mathrm{p}$. 
Leseberg, A., Hockey, P.A.R., and Loewenthal, D., 2000, Human disturbance and the chick-rearing ability of African black oystercatchers (Haematopus moquini): a geographical perspective: Biological Conservation, no. 96 , p. 379-385.

Loegering, J.P., Fraser, J.D., and Loegering, L.L., 1995, Ghost crabs prey on piping plover chick: Wilson Bulletin, v. 107, no., 4, p. 768-769.Lohmann, K.J., and Lohmann, C.M.F., 2003, Orientations mechanisms of hatchling loggerheads, in Bolten, A.B., and Witherington, B.E., eds., Loggerhead Sea Turtles: Washington, D.C., Smithsonian Books, 319 p.

McGowan, C.P., Simons, T.R., Golder, W., and Cordes, J., 2005, A comparison of American Oystercatcher reproductive success on barrier beach and river island habitats in coastal North Carolina: Waterbirds, no. 28 , p. $150-155$.

Melvin, S.M., Griffin, C.R., and Macivor, L.H., 1991, Recovery strategies for piping plovers in managed coastal landscapes: Coastal Management, v. 19, p. 21-34.

Melvin, S.M., Hecht, A., and Griffin, C.R., 1994, Piping plover moralities caused by off-road vehicles on Atlantic coast beaches: Wildlife Society Bulletin, no. 22, p. 409-414.

Miller, J.D., Limpus, C.J., and Godfrey, H.H., 2003, Nest site selection, oviposition, eggs, development, hatching, and emergence of loggerhead turtles, in Bolten, A.B., and Witherington, B.E., eds., Loggerhead Sea Turtles: Washington, D.C., Smithsonian Books, 319 p.

Murphy, R.K., Michaud, I.M.G., Prescott, D.R.C., Ivan, J.S., Anderson, B.F., and French-Pombier, M.L., 2003, Predation on adult piping plovers at predator exclosure cages: Waterbirds, no. 26, p. 150-155.

National Research Council, Committee on Sea Turtle Conservation, 1990, Decline of sea turtles: causes and prevention: Washington, D.C., National Academy Press, 259 p.

National Marine Fisheries Service and U.S. Fish and Wildlife Service (NMFS and USFWS), 1991a, Recovery plan for U.S. population of Loggerhead Turtle: Washington, D.C., National Marine Fisheries Service, 64 p.

National Marine Fisheries Service and U.S. Fish and Wildlife Service (NMFS and USFWS), 1991b, Recovery plan for U.S. population of Atlantic Green Turtle: Washington, D.C., National Marine Fisheries Service, $52 \mathrm{p}$.

National Marine Fisheries Service and U.S. Fish and Wildlife Service (NMFS and USFWS), 1992, Recovery plan for Leatherback Turtles in the U.S. Caribbean, Atlantic and Gulf of Mexico: Washington, D.C., National Marine Fisheries Service, 65 p.

Nicholls, J.L., and Baldassarre, G.A., 1990, Habitat selection and interspecific associations of piping plovers along the Atlantic and Gulf Coasts of the United States: Wilson Bulletin, no. 102, p. 581-590.

Nisbet, I.C.T., 2002, Common tern (Sterna hirundo), in Poole, A., and Gill, F., eds., The birds of North America, No. 618: The Academy of Natual Sciences, Philadelphia, Pennsylvania, and Anerican Ornithologists' Union, Washington, D.C., accessed December 10, 2009, at http://bna.birds.cornell.edu/bna/ species/618/articles/introduction.

Nol, E., and Humphrey, R.C., 1994, American Oystercatcher (Haematopus palliates), in Poole, A., and Gill, F., eds., Philadelphia, PA, The Birds of North America, no. 82: The Academy of Natural Scieneces, Philadelphia, Pennsylvania, and American Ornithologists' Union, Washington, D.C., accessed December 10, 2009, at http://bna.birds.cornell.edu/bna/species/82/articles/introduction. 
Palmer, R.S., 1967, Family Haematopodidae, in Stout, G., ed., Shorebirds of North America: New York, Viking Press, p. 147-150.

Parnell, J.F., and Soots, R.F., Jr., 1979, Atlas of colonial waterbirds of North Carolina estuaries: Raleigh, North Carolina, UNC Sea Grant Publication, UNC-SG-78-10, 269 p.

Parnell, J.F., Erwin, R.M., and Molina, K.C., 1995, Gull-billed (Sterna nilotica), in Poole, A., and Gill, F., eds., The Birds of North America, no. 140: The Academy of Natural Sciences, Philadelphia, Pennsylvania, and American Ornithologists' Union, Washington, D.C., accessed December 10, 2009, at http://bna.birds. cornell.edu/bna/species/140/articles/introduction.

Patterson, M.E., Fraser, J.D., and Roggenbuck, J.W., 1991, Factors affecting piping plover productivity on Assateague Island: Journal of Wildlife Management, no. 55, p. 525-531.

Rabon, D.R., Johnson, S., Boettcher, R., Dodd, M., Lyons, M., Murphy, S., Ramsey, S., Roff, S., and Stewart, K., 2003, Confirmed leatherback turtle (Dermochelys coriacea) nest from North Carolina, with summary of leatherback nesting activities north of Florida: Marine Turtle Newsletter, no. 101, p. 4-8.

Sabine, J.B., III, 2005, Effects of human activity and predation on breeding American Oystercatchers: Athens, Georgia, The University of Georgia, unpublished M.S. thesis, 99 p.

Simons, T.R., Schulte, S., Cordes, J., Lyons, Marcia, and Golder, W., 2004, American Oystercatcher (Haemaotpus paliatus) research and monitoring in North Carolina: Raleigh, North Carolina, Annual report, North Carolina Cooperative Fish and Wildlife Research Unit, Department of Zoology, North Carolina State University.

Steinitz, M.J., Salmon, M., and Wyneken, J., 1998, Beach renourishment and loggerhead turtle reproduction: A seven year study at Jupiter Island, Florida: Journal of Coastal Research, v., 14, no. 3, p. 1,000-1,013.

Strauss, E.G., 1990, Reproductive success, life history patterns, and behavioral variation in a population of Piping Plovers subjected to human disturbance: Medford, MA, Tufts University, unpublished Ph.D. dissertation, $143 \mathrm{p}$.

Thompson, B.C., Jackson, J.A., Burger, J., Hill, L.A ., Kirsch, E.M., and Atwood, J.L., 1997, Least tern (Sterna antillarum), in Poole, A., and Gill, F., eds., The birds of North America, No. 290: The Academy of Natural Sciences, Philadelphia, Pennsylvania, and American Ornithologists' Union, Washington, D.C., accessed December 10, 2009, at http://bna.birds.cornell.edu/bna/species/290/articles/introduction.

U.S. Fish and Wildlife Service, 1993, Endangered and threatened wildlife and plants; determination of seabeach amaranth (Amarnathus pumilus) to a threatened species: Federal Register 58 (65), p. 18,035-18,042.

U.S. Fish and Wildlife Service, 1996, Recovery plan for Seabeach Amaranthus (Amaranthus pumilus): Atlanta, Georgia, Southeast Region, 59 p.

U.S. Fish and Wildlife Service, 1996, Piping Plover (Charadrius melodus), Atlantic Coast Population, Revised Recovery Plan: Hadley, Massachusetts, 258 p.

U.S. Fish and Wildlife Service, 2005, Seabeach Amaranth (Amaranthus pumilus), U.S. Fish and Wildlife Service, North Carolina Ecological Services, Raleigh Field Office, accessed 2005 at http://www.fws.gov/nc-es/plant/seabeachamaranth.html.

Verboven, N., Ens, B.J., and Dechesne, S., 2001, Effect of investigator disturbance on nest attendance and egg predation in Eurasian Oystercatchers: Auk, no. 118, p. 503-508. 
Verhulst, S., Oosterbeek, K., and Ens, B.J., 2001, Experimental evidence for effects of human disturbance on foraging and parental care in oystercatchers: Biological Conservation, no. 101, p. 375-380.

Watts, B.D., and Bradshaw, D.S., 1995, Ghost crabs prey on Piping Plover eggs: Wilson Bulletin, no. 107, p. $767-768$.

Weakley, A., and Bucher, M., 1991, Status survey of seabeach amaranth (Amaranthus pumilus Rafinesque) in North and South Carolina, (2d ed.), (after Hurricane Hugo): Report to North Carolina Plant Conservation Program, North Carolina Department of Agriculture, Raleigh, North Carolina, and Asheville Field Office, U.S. Fish and Wildlife Serevice, Asheville, North Carolina, 149 p.

Witherington, B.E., and Martin, R.E., 1996, Understanding, assessing, and resolving light-pollution problems on sea turtle nesting beaches: Florida Marine Research Institute, FMRI Technical Report TR-2, 73 p.

Wolcott, D.L., and Wolcott, T.G., 1999, High mortality of piping plovers on beaches with abundant ghost crabs: correlation not causation: Wilson Bulletin, no. 111, p. 321-329.

Zonick, C.A., 2000, The winter ecology of piping plovers (Charadrius melodus) along the Texas Gulf Coast: Columbia, Missouri, University of Missouri, Ph.D. dissertation, 169 p. 


\title{
Chapter 1-Management and Protection Protocols for the Threatened Piping Plover on Cape Hatteras National Seashore, North Carolina
}

\author{
By Jonathan B. Cohen
}

\section{Executive Summary}

1. The breeding population of the piping plover (Charadrius melodus), a federally-threatened shorebird, at Cape Hatteras National Seashore (CAHA) declined from 15 pairs/year (yr) to 3 pairs/yr from 1989-2004. A population of this size may face immediate risk of extirpation from several sources. At several former breeding sites at CAHA, there have been no nesting pairs in recent years.

2. Only one plover chick has survived to fledging at CAHA, 2001-2004. While survival of eggs has often been moderate to high since 1989, survival of chicks has generally been low. Reproductive rate improved in 2005, with 6 chicks fledging from 2 pairs in conjunction with more actively managed closures in brood-rearing areas.

3. Inclement weather, predation, and recreational disturbance may negatively impact reproductive success of piping plovers at CAHA. Recreational disturbance and habitat loss caused by ORVs may discourage pairs from attempting to nest.

4. To recover the breeding plover population at CAHA, it will be necessary to create disturbance-free areas containing high-quality nesting and foraging habitat from the territory-establishment phase to the brood-rearing phase of the breeding cycle. We provide three management options to reduce risk of disturbance and mortality. They entail full closure of the seashore to recreation, closure of historical breeding sites to ORVs, or restriction of recreation to an oceanside corridor.

5. To reduce the risk of egg and chick mortality, we recommend continued efforts to trap and remove mammalian predators from all aforementioned sites and the continued use of predator exclosures around nests. We further recommend intensive monitoring and surveillance of protected areas to determine the extent and timing of threats to nests and broods, including nest overwash, predation, and disturbance or vandalism by humans.

6. Even if reproductive success improves under our recommendations, however, a population of this size will take several years to recover in the absence of immigrants from other sites, and there may not be a noticeable increase in population size in the short term. We recommend using an Adaptive Management approach, combining research, monitoring and management to assess the effectiveness of management actions in achieving our goals to recovery this threatened species at Cape Hatteras.

7. The size of nonbreeding flocks, their habitat use, their site tenacity, and sources of disturbance and mortality are not known with high precision. We recommend monitoring standards and research to address this problem, while at the same time restricting recreation adjacent to important migration and wintering sites to afford nonbreeding birds increased protection.

\section{Introduction}

The Atlantic Coast population of the piping plover (Charadrius melodus) was federally listed in 1986 as threatened (Federal Register, 2001). At that time approximately 790 pairs remained and the species was in decline (USFWS, 1996). Habitat loss caused by human development and recreation, and low reproductive rates caused by human disturbance and predation were considered to be the primary causes of the decline (Haig, 1992). Disturbance and predation were intensively managed after listing, and the population rebounded 
to 1,676 pairs by 2003 (USFWS, 2004), but was still short of the recovery goal of 2,000 pairs (USFWS, 1996). The population south of New Jersey was estimated at 203 pairs in 2003, well short of the regional goal for the southern Atlantic Coast (DE, MD, VA, NC, SC) of 400 pairs, and North Carolina itself experienced a greater than (>) 50 percent (\%) decline in breeding pairs from 1989 to 2003 (USFWS, 2004).

No published accounts exist of breeding piping plovers in North Carolina from 1902 to 1960, when a pair was found on Ocracoke Island (Golder, 1985). Four nests and one brood were discovered within the boundaries of Cape Hatteras National Seashore (CAHA) (fig.1-1) in 1984 incidental to monitoring of other species, and 5 chicks were known to have fledged that year (Golder, 1985). Nine pairs were counted in 1986, again incidentally (Golder, 1986), and 10 pairs were discovered in 1987 in specific surveys for the plover (Cooper, 1990). The plover population reached a high of 15 pairs in 1989 and varied between 11 and 14 pairs until 1996, after which a sharp decline began. The population reached a low of 2 breeding pairs in 2002 and 2003 with only 3 breeding pairs reported in 2004 (fig. 1-2, Lyons, 2001; Lyons, 2002; Lyons, 2003; Lyons, 2004; M. Lyons, National Park Service, written commun., 2004), and 2 in 2005. Plovers breeding at CAHA have had to coexist with increasingly higher numbers of human visitors to the park. From 1986-2004, the number of recreational visitors to CAHA increased 44\%, from 1.54 million/yr to $2.21 \mathrm{million} / \mathrm{yr}$ (NPS 2005). Specifically, there was a $29 \%$ increase in visitation in the plover nonbreeding months (Sept.-Feb.) from 0.57 million/yr to 0.73 million/yr, and a $52 \%$ increase in the plover breeding months (Mar.-Aug.) from $0.97 \mathrm{million} / \mathrm{yr}$ to $1.48 \mathrm{million} / \mathrm{yr}$.

Small populations may face a risk of immediate extinction from several general sources. These include environmental stochasticity (i.e., random environmental variation, such as storm events), inbreeding depression, genetic stochasticity (i.e., random variation of genotypes, which may not be adapted to local conditions), demographic stochasticity (i.e., random variation in birth and death rates), and the Allee effect, in which organisms are unable to find mates (Lande, 1988).

Given the vulnerability of the small plover population at CAHA to extinction due to random events, the persistence of the population will depend partly on controlling non-random sources of mortality to adults, eggs, and chicks. Predators, human disturbance, and access to foraging habitat have been identified in past research as limiting reproductive success at CAHA (Coutu and others, 1990; Kuklinski and others, 1996). There may be evidence for an Allee effect at CAHA, as plover monitoring reports from 2001-2003 and preliminary observations from 2005 indicate that unpaired birds displaying territorial behavior were observed in the pre-laying period at several sites (Lyons, 2001; Lyons, 2002; Lyons, 2003). Thus, providing a disturbancefree environment early in the season may assist plovers attempting to establish territories and attract mates.

In addition to its declining breeding population, CAHA is used by migrating plovers and by wintering plovers from the threatened Atlantic Coast and Great Plains populations and the endangered Great Lakes population. The dynamics of the nonbreeding populations at CAHA are less-well documented than for the breeding populations. However, gathering information about and protecting nonbreeding plovers and their habitat is a priority in the recovery plans for all three North American breeding populations (Haid and others, 1988; USFWS, 1996; USFWS, 2003).

The following management plan is intended to provide guidance for reducing risk of mortality and disturbance to breeding and nonbreeding birds and increasing breeding success. Even if reproductive success improves under our recommendations, however, a breeding population of this size will take several years to recover in the absence of immigrants from other sites, and there may not be a noticeable increase in population size in the short term. These protocols are based on current biological knowledge. It will be up to the National Park Service (NPS) to decide how best to incorporate these protocols into a more comprehensive management plan, given the logistical and political realities faced by CAHA, and protocols for protection of other species. Finally, the protocols below provide site-specific recommendations and are intended to apply only to lands within the jurisdiction of CAHA.

The USGS Patuxent Wildlife Research Center developed these protocols, based on the best available scientific information, to guide management, monitoring and research activity at CAHA that would result in the protection and recovery of each species. These protocols do not attempt to balance the need for protection of these species with other activities that occur at CAHA, nor was NPS management policy considered in detail. A draft of the protocols was sent to species experts for scientific review; the final draft of protocols were reviewed by NPS personnel to ensure that description of recent management at CAHA was accurately represented and that the approach was consistent with our work agreement. 


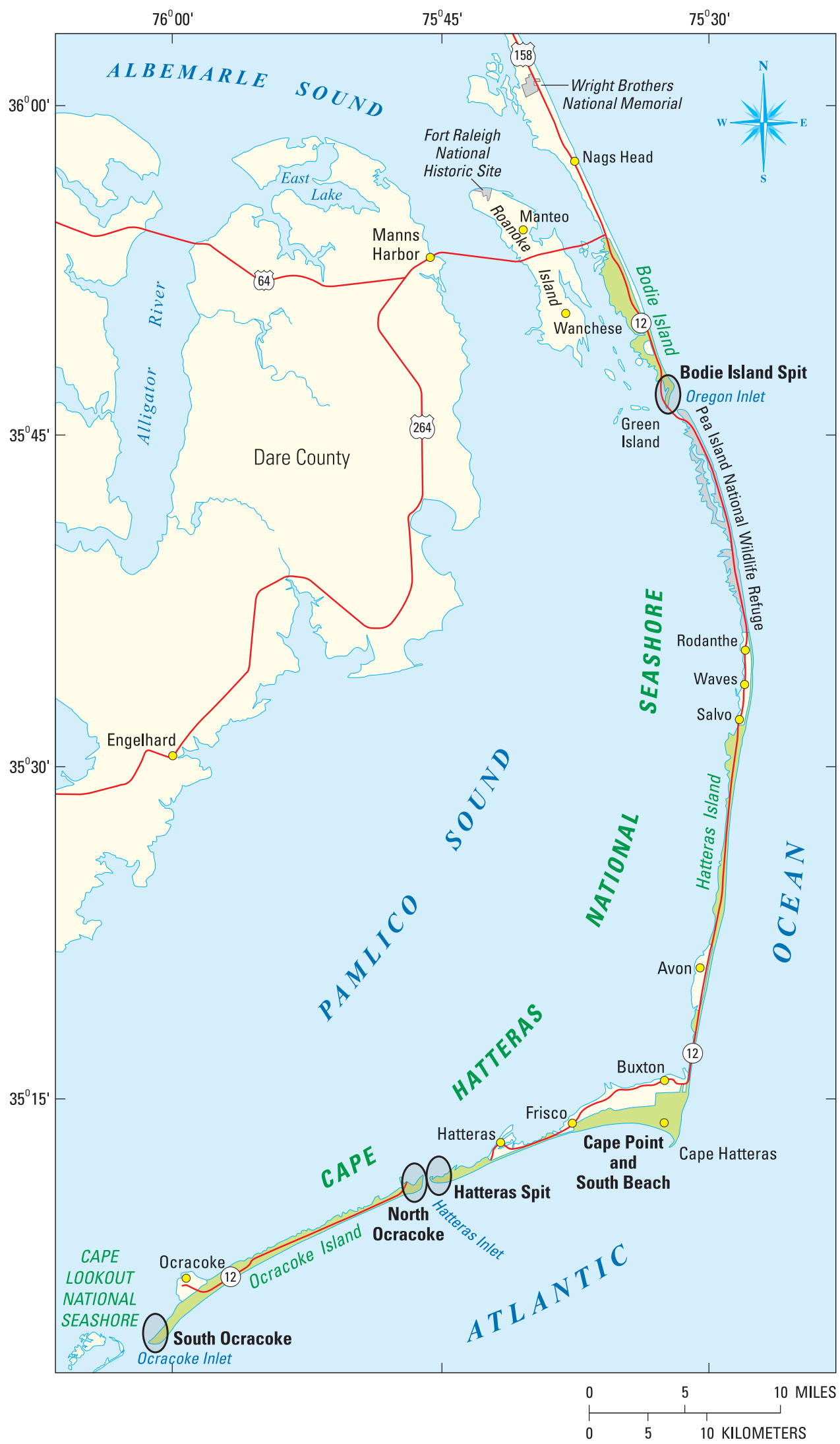

Figure 1-1. Cape Hatteras National Seashore, North Carolina. Ovals and bold labels indicate recent plover breeding areas (modified from National Park Service map). 


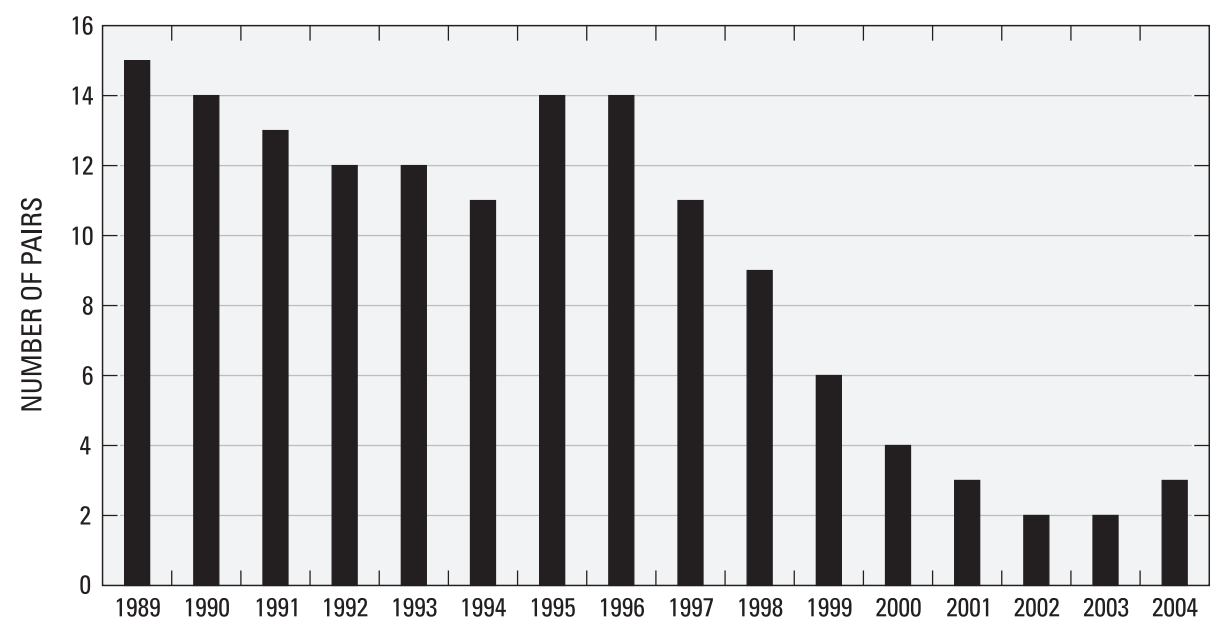

Figure 1-2. Number of piping plover nesting pairs, Cape Hatteras National Seashore, North Carolina,1989-2004.

\section{Distribution and Breeding Biology}

The piping plover is a small $[17-18$ centimeters (cm) long, 43-63 grams (g)] sand-colored shorebird endemic to North America (Haig 1992). Breeding piping plovers occur in three distinct sub-populations: the Atlantic Coast (from the Maritime Provinces of Canada to the Outer Banks of North Carolina), the Great Lakes (along Lake Superior and Lake Michigan), and the Great Plains (from southern prairie Canada to Iowa). Wintering populations occur on the Atlantic Coast from North Carolina to Florida, and the Gulf Coast from

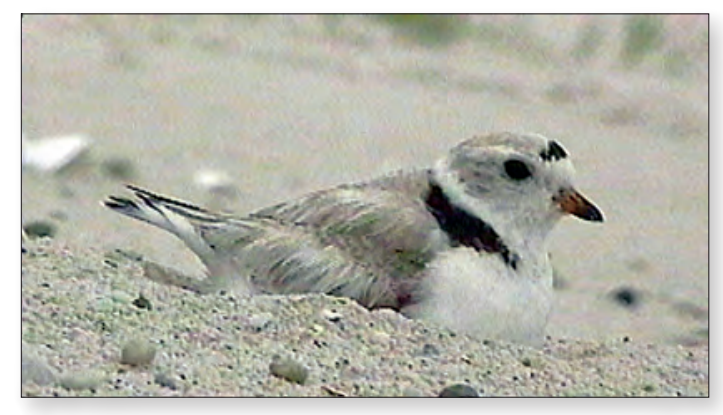

Piping plover (Charadrius melodus). Photograph by Jonathan B. Cohen. Florida to Mexico and the Carribean.

On the Atlantic Coast, breeding territory establishment and courtship generally begin in late March, the first nests are initiated in late April, and the brood-rearing period extends from late May to mid-August. In contrast, peak arrival in the Great Plains is the third week of April. Departure from the breeding grounds extends from mid-July to early September. Residency on the wintering grounds occurs from mid-July through early May, with the duration depending on the location.

The mating system is monogamous, although retention of the same mate between breeding seasons is variable. The nest consists of a shallow scrape in the substrate created by the male, often lined with shell fragments. Four is the modal clutch size, and one egg is laid every other day until the clutch is complete. Incubation typically commences the day of clutch completion, but sometimes when the penultimate egg is laid, and members of a pair share incubation duties. The eggs and chicks are cryptically-colored. Incubation time ranges from 25-29 days. A pair will renest multiple times if successive clutches are destroyed, but renesting after the chicks hatch is rare. Chicks leave the nest scrape within a few hours of hatching, and never return except where a nest hatches at night (Wolcott and Wolcott,1999). Members of a pair share brood-rearing duties (which comprise defending a brood-rearing habitat, brooding, giving alarm calls, and leading the chicks to foraging and roosting habitat), however females are known to desert their brood within the first week after hatch, a behavior observed frequently in one New York study (Cohen, 2005) but infrequently elsewhere on the the Atlantic Coast. Although chicks follow adults to foraging habitat, they forage for themselves. Fledging time ranges from 21-35 days (R. Boettcher, Virginia Department of Game and Inland Fisheries, pers. comm.). 


\section{Breeding at CAHA}

1989-2004. - The National Park Service began monitoring plovers at CAHA in 1989. Six primary nesting sites have been identified (fig. 1-1). These are Bodie Island Spit at the south end of Bodie Island, Cape Hatteras Point (Cape Point), South Beach, and Hatteras Spit on Hatteras Island, and the north and south tips of Ocracoke Island (NPS unpublished data, 2004). Locally-breeding plovers arrive at CAHA in mid-March, begin courting and pairing in April, and begin to initiate nests the third week of April (Coutu and others, 1990).

Bodie Island Spit had one pair of breeding plovers in 1996, 1997, 2001, 2002, and 2004. Mean nest survival (nests that hatched at least one egg/nests laid) was $40 \%$, mean chick survival (chicks fledged/eggs hatched) was $0 \%$, and mean reproductive rate (chicks fledged/pair) was 0.00 .

Cape Point had 4-6 breeding pairs of plovers/yr from 1992-1996, after which the number of pairs declined to 1 pair/yr by 2001. No pairs were found at this site from 2002-2004. Mean nest survival was 64\% and mean chick survival was $37 \%$. Reproductive rate ranged from 0.00 in 2001 to 1.70 fledglings/pair in 1999, and averaged 0.85 .

South Beach had 1 pair of plovers/yr from 1993-1999. Mean nest survival was 93\% and mean chick survival was 36\%. Reproductive rate ranged from 0.00 (in several years) to 2.0 fledglings/pair (in 1998 and 1999), and averaged 0.67.

At Hatteras Spit, 3-5 pairs nested/yr from 1992-1998, and 1-2 pairs nested from 1999-2004, including one pair in 2004. Mean nest survival was $40 \%$ and mean chick survival was $22 \%$. Reproductive rate ranged from 0.00 (in several years including 2002-2004) to 2.00 fledglings/pair in 2001, and averaged 0.47.

North Ocracoke had 1-4 breeding pairs/yr from 1992-1996. Mean nest survival was 36\% and mean chick survival was $43 \%$. Reproductive rate ranged from 0.00 to 0.50 fledglings/pair and averaged 0.30 . South Ocracoke had 1-2 breeding pairs from 1995-1999, and 1 breeding pair in 2003-2004. Mean nest survival was $67 \%$ and mean chick survival was $25 \%$. Reproductive rate ranged from 0.00 (in several years) to 4.00 fledglings/pair in 1998, and averaged 0.70 .

Mean nest survival at these CAHA sites was moderate to high when compared with nest survival at other breeding grounds, while chick survival was low (Mayer and Ryan, 1991; Patterson and others, 1991; Loegering and Fraser, 1995; Goldin and Regosin, 1998). Except at South Beach, however, where nest survival was $100 \%$ in all years but one, nest survival varied greatly among years. Chick survival was highly variable at all sites. With all sites pooled, reproductive rate was correlated with chick survival $(r=0.87, P<0.001, n=13$ yr), but not nest survival $(r=0.16, P=0.603, n=13 \mathrm{yr})$.

2005. - In 2005, there was evidence of territory prospecting by at least one pair at Bodie Island Spit, at least one pair at South Ocracoke, one pair at Hatteras Spit, and two pairs at Cape Point. Ultimately, nests were found for one pair at Hatteras Spit and one pair at Cape Point. Each pair fledged 3 chicks.

\section{Nonbreeding Plovers at CAHA}

North Carolina is currently the only state on the Atlantic Coast that has piping plovers during all phases of the annual cycle. Band sightings indicate that plovers from all three North American breeding populations

use CAHA during migration and/or the winter, and plovers from the endangered Great Lakes population have been documented in fall and spring migration and the wintering period. All plover breeding sites at CAHA were designated as critical habitat for wintering birds, as defined by the Endangered Species Act (Federal Register, 1985) until 2004, when a court decision vacated the designation for Oregon Inlet, Cape Point, Hatteras Inlet, and Ocracoke Island (Cape Hatteras Access Preservation Alliance vs. U.S. Dept. of the Interior, 344 F. Supp. 2d 108 (2004)).

From 2000-2005, the greatest number of nonbreeding plovers at CAHA occurred during fall migration, which begins in July and peaks between July and September (table 1-1). The fall counts were highest at South Ocracoke, followed by Oregon Inlet (Bodie Island Spit, Pea Island National Wildlife Refuge, and formerly Green Island which is now largely unusable due to vegetation growth), then Hatteras Spit and Cape Point. Fall migration may last until November. 
The first banded winter residents have appeared in August, although wintering birds may arrive in July. The nonbreeding population from Dec.-Jan. likely consists entirely of winter residents. The size of the resident wintering population is not precisely known, but it may be on the order of 20-35 birds (table 1-1). Maximum numbers seen were about $50 \%$ of the recent norm in the winter of 2004-2005, but whether that was due to a difference in survey effort is unknown. The highest counts of wintering birds were at Oregon and Ocracoke Inlets. Rarely surveyed shoals, such as Clam Shoal (which is not part of CAHA) in Pamlico Sound, had up to 6-7 plovers when they were checked. Based on a sample of banded birds, winter residents can be present until April.

Spring migrant may appear in February or early March, and their numbers peak in late March or April (table 1-1). Sites at Oregon Inlet have had the highest abundance of spring migrants, followed by Ocracoke Inlet, with lesser numbers at Hatteras Spit and Cape Point. Ecological factors governing the distribution and size of the nonbreeding population at CAHA are unknown.

Table 1-1. Median and maximum nonbreeding birds seen per daily survey during fall, winter, and spring, selected sites at Cape Hatteras National Seashore, 2000-2005.

[Note: Not all sites were surveyed each day (typically only one or two were surveyed), so these numbers provide only a rough idea of the total size of the nonbreeding population.]

\begin{tabular}{|c|c|c|c|c|c|}
\hline Month & Oregon Inlet & $\begin{array}{l}\text { Cape Point/ } \\
\text { South Beach }\end{array}$ & Hatteras Inlet & Ocracoke Inlet & All sites \\
\hline \multicolumn{6}{|c|}{ Median } \\
\hline Jul & 0.49 & 0.18 & 0.45 & 2.21 & 5.67 \\
\hline Aug & 0.68 & 0.31 & 0.13 & 3.76 & 6.43 \\
\hline Sept & 0.66 & 0.07 & 0.38 & 4.22 & 5.67 \\
\hline Oct & 0.36 & 0.00 & 0.86 & 1.81 & 3.33 \\
\hline Nov & 0.82 & 0.00 & 0.07 & 1.00 & 4.21 \\
\hline Dec & 0.77 & 0.00 & 0.00 & 2.07 & 2.88 \\
\hline Jan & 0.25 & 0.00 & 0.00 & 1.00 & 1.18 \\
\hline Feb & 3.33 & 0.00 & 0.00 & 1.00 & 4.33 \\
\hline Mar & 1.25 & 0.00 & 0.00 & 0.75 & 2.75 \\
\hline Apr & 1.89 & 0.00 & 0.62 & 1.31 & 3.60 \\
\hline \multicolumn{6}{|c|}{ Maximum } \\
\hline Jul & 32 & 5 & 21 & 56 & 56 \\
\hline Aug & 34 & 6 & 14 & 72 & 72 \\
\hline Sept & 16 & 5 & 4 & 37 & 37 \\
\hline Oct & 12 & 1 & 28 & 31 & 31 \\
\hline Nov & 15 & 0 & 8 & 12 & 15 \\
\hline Dec & 17 & 0 & 7 & 15 & 17 \\
\hline Jan & 18 & 0 & 1 & 11 & 18 \\
\hline Feb & 14 & 0 & 0 & 18 & 18 \\
\hline Mar & 12 & 3 & 4 & 8 & 12 \\
\hline Apr & 25 & 3 & 7 & 11 & 25 \\
\hline
\end{tabular}




\section{Habitat and Foraging Ecology}

\section{Breeding Habitat}

Nesting.- On the Atlantic Coast, piping plovers nest in sand, gravel, or cobble substrates in backshore, dune, interdune blowout, overwash fan, and barrier flat zones of open or sparsely-vegetated beaches (Haig, 1992). Nests sites may have little or no slope (Cairns, 1982; Burger, 1987), although nesting does occur on lower-elevation dunes (Cairns, 1982). On wide beaches, plovers nest in the open to maintain a wide field of view, but on narrower beaches eggs can be laid in clumps of vegetation (Cairns, 1982). On Assateague Island, Maryland, mean vegetative cover within 1 meter $(\mathrm{m})$ of nest sites ranged up to $19.3 \%$ for depredated nests, and up to $14.8 \%$ for other nests (not significantly different, $P>0.05$, Patterson and others, 1991). In New Jersey, substrate with $5-20 \%$ shell cover was preferred over sites with no shell cover (Burger, 1987). Where beaches are wide enough, plovers nest far from the tide line to reduce risk of nest overwash, but this places nests closer to vegetated dunes where risk of predation is high (Burger, 1987). In Virginia, Piping Plovers typically nest on the backside of overwash fans that have a minimum of $25 \%$ shell cover and offer unimpeded access to backside MOSH (R. Boettcher, VA Dept. Game and Inland Fisheries, pers. comm.).

Foraging.-Plovers prey mainly on terrestrial arthropods and benthic worms (Haig, 1992). Adults forage both day and night (Staine and Burger, 1994), but young chicks are brooded during the night (Wolcott and Wolcott, 1999), although they are still vulnerable to nocturnal mortality due to weather, predation, or human activity. During territory establishment, foraging adults exhibit a preference for low-wave energy moist substrate habitats (MOSH) for foraging, especially intertidal mudflats and sandflats (Keane and others, in press). Benthic invertebrates in MOSH provide prey at a time of year when terrestrial arthropods are scarce (Houghton, 2005), and in Massachusetts were found to be more abundant than in the high-wave energy ocean intertidal zone (Hoopes, 1993). Foraging broods exhibit a preference for wrack and MOSH, including mudflats, sandflats, and ephemeral pools (Goldin, 1993; Hoopes, 1993; Kuklinski and others, 1996; Elias and others 2000). Such habitat has a higher abundance of terrestrial arthropods than drier zones (Hoopes 1993; Loegering and Fraser, 1995; Kuklinski and others, 1996; Elias and others, 2000).

Breeding Habitat at CAHA.- - In 1989, plovers at CAHA were observed to lay 50\% of their nest attempts on the ocean beach, 37\% on the dune toe, and 5\% (1 nest) in an overwash (Coutu and others, 1990). Broods foraged primarily on damp sand flats (Coutu and others, 1990), where their percent time spent foraging, foraging rate (pecks/min), and prey abundance was much higher than in other habitats (Kuklinski and others, 1996). Brood percent use of ocean fresh wrack, sparse vegetation, wet sand flat, and overwash was greater than expected based on the percent availability of those habitats (Kuklinski and others, 1996).

\section{Foraging Habitat Availability}

Chicks with access to MOSH survived better than chicks without such access in Virginia (Loegering and Fraser, 1995), Rhode Island (Goldin and Regosin, 1998), and in some years in New York (Elias and others, 2000). Burger (1994) found that having a diversity of foraging habitat zones available to broods reduced the impact of human disturbance, because it provided opportunities for chicks to escape disturbance and still forage.

\section{Winter}

Wintering plovers on the Atlantic Coast select wide beaches in the vicinity of inlets that are associated with a high percent area of MOSH (Nicholls and Baldassarre, 1990; Wilkinson and Spinks, 1994). In coastal Alabama, MOSH was the primary foraging habitat, while sandy beaches served as roosting habitat (Johnson and Baldassarre, 1988). Wintering plovers in Texas exhibited a preference for algal flats and sandflats (Drake and others, 2001). Because tide and weather variation often cause plovers to move among habitat patches, a complex of patches may be important to local wintering populations (Nicholls and Baldassarre, 1990). 


\section{Threats to Survival and Reproductive Success}

\section{Weather and Tides}

Direct effects. - Storm events lead to unusually high tides and flooding that can overwash plover nests (Haig, 1992). Plovers may also nest close enough to the tide line to lose their nests on normal high tides. Storms can also result in widespread mortality of chicks (Houghton, 2005). In New York, nest and chick survival were higher in warm, dry years than cool, wet years (Cohen and others, written commun., 2009). Temperature, however, was not a factor limiting productivity in one study at CAHA (Kuklinski and others, 1996). The effects of weather on winter survival are unknown for piping plovers, but high survival (100\%) in a wintering population in Texas was speculated to be partly a function of a mild climate, as well as a lack of study sites adjacent to areas of human disturbance (Drake and others, 2001).

Indirect effects. - Flooding due to tides or weather may alter habitat enough to render it unsuitable for nesting. This may lead to territory abandonment within or among breeding seasons (Haig and Oring, 1988).

\section{Predation}

Direct effects. - Predation is a primary factor limiting reproductive success of the piping plover (Haig 1992). Predators of eggs, chicks, and/or adults include mink (Mustela vison), red fox (Vulpes vulpes), striped skunks (Mephitis mephitis), opossum (Didelphis marsupilais), domestic dogs, feral and domestic cats, crows (Corvus spp.), and gulls (Larus spp.) (Haig, 1992), as well as raptors (Murphy and others, 2003a) and blackbirds (Icteridae) (Cohen and others, written commun., 2009).

Ghost crabs (Ocypode quadrata) have occasionally been implicated in the loss of nests (Watts and Bradshaw, 1995) and chicks (Loegering and others, 1995). At Chincoteague National Wildlife Refuge in Virginia, however, interactions between crabs and plovers did not result in predation of eggs or chicks, even on beaches where crabs were very abundant (Wolcott and Wolcott, 1999). Furthermore, ghost crabs could not be induced to prey on quail (Coturnix japonicus and Colinus virginianus) eggs and chicks in field and laboratory experiments, even when foraging behavior was elicited in the crabs with bait (Wolcott and Wolcott, 1999). Anecdotal evidence indicates that ghost crabs may be more of a problem in North Carolina than at sites further north (D. Allen, North Carolina Wildlife Resources Commission, pers. comm..)

Indirect effects.- Reproductive failure due to predation apparently led to abandonment of territories within and between breeding seasons, specifically when population-level reproduction was poor (Cohen, 2005). This effect was not demonstrated in the Great Plains (Haig and Oring, 1988; Wiens and Cuthbert, 1988). The consquences of site abandonment to adult survival and future reproductive success are unknown.

\section{Human Activities}

Direct Effects.- Human pedestrians and joggers occasionally destroy nests or kill chicks, either by intentional vandalism or by accident (Patterson and others, 1991; Houghton, 2005). Furthermore, ORVs can run over adults, nests, and chicks, which may run or crouch in vehicle tracks in response to danger. Chicks are difficult to see in this situation due to their cryptic coloration (Melvin and others, 1994). Human development and recreation results in loss or degradation of breeding habitat (Haig, 1992). Off-road vehicle (ORV) use has been demonstrated to destroy the wrack line (Goldin, 1993), thereby degrading an important foraging habitat. Breeding and nonbreeding birds are subject to disturbance (disruption of normal activities) by ORVs and pedestrians.

Beach renourishment and artificial dune construction to protect human structures from storm damage may temporarily increase the size of nesting areas (Melvin and others, 1991). However, there are negative indirect effects associated with renourishment (see below).

Indirect Effects.-The impact of predation has been postulated to be greater on beaches with high human use, because the presence of pets and trash that may attract wild predators is correlated with the presence of humans (USFWS, 1996). In some studies, beaches with high levels of human disturbance had lower 
reproductive rates than less-disturbed beaches (Cairns, 1982; Flemming and others, 1988). At other sites, disturbance did not affect reproductive rate (Patterson and others, 1991; Hoopes, 1993; Burger, 1994), although pedestrians, kites, and ORVs caused a decrease in brood foraging behavior in Massachusetts (Hoopes, 1993) and New Jersey (Burger, 1994). It is important to note, however, that in the high-disturbance sites in the above studies, disturbance was being actively managed to protect plovers. In New York, the response of incubating adults to the presence of humans near the nest was found to be highly variable, ranging from delayed laying schedules or nest abandonment to no effect. Average nest success, however, was unrelated to the number of disturbance sources observed within $100 \mathrm{~m}$ of nests during daily monitoring (Cohen and others, written commun., 2009). Plovers may be more sensitive to disturbance in the Atlantic Coast southern recovery unit, as evidenced by longer flush distances in response to disturbance sources at Assateague National Seashore (Loegering, 1992). In Texas, plovers avoided foraging on sandflats close to areas of high human use (Drake and others, 2001). Zonick (2000) found that the number of plovers was lower on disturbed bayside flats than undisturbed flats, and that plovers experienced lower foraging efficiency when disturbed. Other unpublished data support the assertion that winter habitat selection is negatively correlated with human activities and development.

ORV use affects the geomorphology of the beach through sand displacement and compaction, which may lead to steeper dune profiles (Anders and Leatherman, 1987), which may be unsuitable for plover nesting. Destruction of the wrackline by ORVs may decrease reproductive success due to loss of important habitat used for foraging and cover (Goldin, 1993).

Renourishment projects alter the profile of beaches causing increased erosion and habitat loss over longer periods (Leatherman and Allen, 1995). Furthermore, beach stabilization prevents normal storm processes such as overwash fan formation, thereby leading to long-term loss of MOSH and accelerated vegetative succession in potential nesting habitat (Dolan and others, 1973). A cumulative effect of renourishment occurs when it is followed by human development. Construction of human structures on beaches eliminates breeding territories, and may result in an increased level of human disturbance of and predation on remaining pairs

(Houghton, 2005). Since wintering populations have been shown to prefer areas around inlets, artificial closure of storm-created inlets may be expected to reduce local carrying capacity for nonbreeding birds.

\section{Threats at CAHA}

Predation, human disturbance, and inclement weather have been implicated as causes of low reproductive success at CAHA (Cooper, 1990; Coutu and others, 1990; Kuklinski and others, 1996; Lyons, 2002; Lyons, 2003; Lyons, 2004). Poor nutrition of broods without access to MOSH was also suspected as a source of mortality in one study (Kuklinski and others, 1996).

In 1996, nest predation varied among sites and was most severe at Hatteras Spit. Nest abandonment increased from 2000-2002 compared to previous years, but no nests were lost in 2003, of the 2 laid. Abandonment was sometimes associated with predator trails circling nest exclosures (Lyons, 2002; Lyons, 2003; Lyons, 2004). A nest was lost to flooding in 2002. In 2001-2003, sources of chick loss were unknown. Chick mortality, however, sometimes followed a rain event. After the disappearance of some chicks, predator trails were found where the brood was last seen, including red fox, domestic dog, and cat (Lyons, 2002; Lyons, 2003).

In 1990, research indicated that enforcement levels at the time were not adequate to keep pedestrians, pets, and ORVs out of restricted plover breeding areas (Coutu and others, 1990). In 1996 potential disturbance sources remained apparently outside of protected areas, and predation rather than disturbance was considered the major direct threat to reproductive success (Kuklinski and others, 1996), although fieldwork did not begin until May 30 and missed the first part of the nesting season. Documented violations of protected areas by pedestrians began to increase sharply after 2000, but this may have been due in part to more careful recording of incidents (Lyons, 2002; Lyons, 2003; Lyons, 2004). Approximately 50-60 incidents of ORVs entering protected areas were recorded each year from 2000-2002, and in 2003 the symbolic fence was vandalized by an ORV and several instances of ORVs within the protected area were observed (Lyons, 2002; Lyons, 2003; Lyons 2004).

Rates and sources of mortality and disturbance and responses of plovers to disturbance in the nonbreeding period have not been assessed at CAHA. Plover foraging and roosting habitat, however, is used by 
pedestrians and ORVs year round. The potential therefore exists for direct mortality of plovers due to ORVs (Melvin and others, 1994) and domestic pets, and disturbance to roosting and foraging birds which may reduce foraging efficiency or alter habitat use thereby increasing the risk of nutritional or thermal stress (Zonick, 2000).

\section{Protection Measures}

Management of breeding populations on the Atlantic Coast has focused on predation control and reduction of human disturbance and risk of mortality due to pedestrians and ORVs (USFWS, 1996; Erwin and others, 2002). Predator exclosure cages placed around nests have successfully reduced nest losses (Melvin and others, 1992; Erwin and others, 2002) and may contribute greatly to population recovery (Larson and others, 2002). Predators, however, may learn to hunt adult plovers at exclosures (Murphy and others, 2003a). Furthermore, the technique does not promote self-sustaining populations in the long term because it does not eliminate predators (Johnson and Oring, 2002). Electric fences around nesting and brood-rearing areas have been used successfully to improve reproductive rate in the Great Plains (Mayer and Ryan, 1991), but may provide little extra benefit over exclosures in places where chick survival is not limiting reproductive success (Murphy and others, 2003b). On the coast, electric fences may be difficult to maintain (USFWS, 1996).

Reduction of human disturbance usually entails erection of a series of special "Bird Nesting" signs connected by string, termed "symbolic fence," around nests or nesting habitat (USFWS, 1996; Erwin and others, 2002). Protection from disturbance also entails closure of beaches to ORVs and pedestrian traffic during part or all of the breeding period, and restrictions on pets, kites, trash disposal, and other potential disturbances (USFWS, 1996).

\section{Recent Management at CAHA}

Additional management needs for Hatteras Inlet were enumerated in the Atlantic Coast revised recovery plan as predator exclosures, additional predator control, vegetation control, monitoring of brood foraging and ORV impacts, additional enforcement of protective rules, intensified wardening, education and outreach, control of feral animals, pet restrictions, and clarification of signs (USFWS, 1996).

At CAHA starting in 2004, ORV traffic is restricted year-round to a 150-foot (ft)-wide corridor parallel to the shoreline, bounded at one side by the average high water line. Vehicles may drive along or park within the corridor. Where there is a primary dune line, this corridor effectively extends to the dune toe in most places. Thus, little to no ocean intertidal zone, ocean wrack, or ocean backshore habitat is free of ORV use between breeding periods. With some exception at the inlets, the dunes, sound side shoreline, and interior features (such as sandflats, overwash fans, and ephemeral pools) are free from ORV use, but not pedestrian use, year round. Pedestrians, but not pets, are permitted outside the ORV corridor at the spits, except where there are specific "resource closures."

Historically-used breeding habitat has been closed to ORVs and pedestrians during the first week of April in most locales in most years (Lyons, 2004), using symbolic fencing with interpretive signs. Such resource closures are off limits to all recreation, including pedestrians and pets. However, this policy is not consistently applied prior to the discovery of nests, and string is not always used to bar the gaps between the signposts until after eggs are laid. In 2003 violations of protected areas by pedestrians and ORVs were frequent, especially at Hatteras Spit, prompting an increased presence of monitors and law enforcement. Breeding sites are sometimes closed to ORVs, to varying degrees, when a nest is expected to hatch (USDOI, 2004).

Predator exclosures are erected around most nests. The effectiveness of exclosures in protecting nests, however, was lower in 2001 (33\% of exclosed nests hatched) and 1999, 2000, and 2002 (50\% of exclosed nests hatched) than in previous years (75-90\% of exclosed nests hatched) due to nest abandonment associated with predator disturbance (Lyons, 2002; Lyons, 2003). From 2002-2005 the NPS undertook trapping to remove mammalian predators from Bodie Island and Hatteras Island. In 2002, 12 foxes were removed from Hatteras Island by U.S. Dept. of Agriculture (USDA) Wildlife Services personnel, and another 16 from Bodie 
Island. USDA officials believed there was still one fox left near South Beach, and a number of foxes on Bodie Island. In 2003, 15 foxes were removed from Bodie Island and 1 from Hatteras, as well as three opossums and one raccoon at Hatteras. CAHA staff removed one feral cat from near Hatteras Inlet. Although a number of foxes were still believed to be on Bodie Island, no fox tracks were seen in plover habitat after trapping began in 2002. Predator removal may enhance the success of exclosures.

CAHA has a leash law but it is loosely enforced. CAHA has no regulations regarding the flying of kites near endangered species areas (Lyons, 2003). With over 70 miles (112 kilometers (km)) of beach to patrol, a limited staff size, and 24 hour public access, biological monitoring and law enforcement are challenging at CAHA.

There are no specific procedures for protection of nonbreeding plover habitat at CAHA. Migrants may currently benefit from nesting area closures (see below), which in some years were left up for an extended period to protect migrants. Furthermore, the current ORV corridor may provide some refuge from disturbance to nonbreeding birds.

In 2005, a 0.1-mile "passthrough only" section of the ORV corridor was enforced at Bodie Island spit, to reduce disturbance to plovers foraging at ephemeral pools close to the original corridor boundary. Pedestrians were not allowed in the passthrough zone. At Cape Point, a resource closure was created around a complex of ephemeral pools to protect an oystercatcher brood (the closure extended to approximately 50 feet from the edge of the pools). This closure was later used by a plover brood that hatched to the west. Cape Point was closed to ORVs after the plover brood moved to the ephemeral pool area. At Hatteras Spit, ORV traffic was only permitted in the ORV corridor once per hour in convoys escorted by bird monitors, to reduce the risk of mortality to an oystercatcher brood and to reduce disturbance to an incubating plover nest. ORVs were permitted to park at the tip of the spit, west of the escort corridor. The spit was closed to recreation at night. Once the plover eggs hatched, Hatteras Spit was closed to ORV traffic until the chicks fledged. At South Ocracoke, the ORV corridor was narrowed in one place to protect a section of ocean intertidal zone where a pair of adult plovers was observed foraging on several occasions. ORVs were permitted to drive past the protected area in the backshore, but were restricted from the shore of the Sound.

Effects of current management.-Current management at CAHA results in the presence of ORVs in oceanside and inlet habitat during the nonbreeding and territory establishment periods, and pedestrians in oceanside, inlet, and soundside habitat. Based on 2005 management, recreation is only restricted from plover habitat when broods of plovers or other species are present, although recreation is kept to a 50-m distance from incubating nests by resource closures. As detailed above (see “Threats to Survival and Reproduction"), the effects of this recreation may include the crushing of adult birds, destruction of the wrack line (leading to a decrease in foraging opportunities for adults and broods), alteration of the beach profile which can affect suitability for nesting, disturbance to adult birds (with possible disruption of territory establishment or decrease in foraging efficiency), vandalism of nests, and an increased presence of domestic and wild predators, that may in turn decrease nest and chick survival or lead to territory abandonment.

\section{Adaptive Resource Management}

Monitoring of floral and fauna over large landscapes should always include three components: a research question(s) aimed at a desired goal, a management approach or experiment to try to determine causality, and a monitoring component to determine the resultant magnitude, duration, and latency of changes associated with the management action or experiment. As monitoring results are revealed, a feedback loop allows the manager to either continue the current management practice or technique, or modify it until the desired trajectory is achieved.

The recent rapid decline in breeding numbers and extremely low population size of breeding plovers at CAHA necessitates the immediate simultaneous management of as many conceivable threats as possible. The effectiveness of management, however, should be assessed in an ongoing manner to the extent possible. This will assist managers in choosing from among the management options recommended below. While improvement in demographic parameters may not be obvious at first regardless of which option is chosen for 
a particular site, changes in behavior, disturbance rates, and abundance of potential predators may be immediately detectable. The research questions detailed below are designed to allow managers to understand the effect of management, as well as to set more specific management goals.

\section{Questions to be Addressed by Research and Monitoring}

1. What is the nesting population, where are nests located, and what is their hatching and fledging success?

2. What is the size of the wintering population, where are the flocks located, how site faithful are they, and how much movement is there between them?

3. What factors limit the size and distribution of breeding and nonbreeding populations?

4. How do young and adults use nesting and feeding habitat (breeding, migration, and winter seasons)? How much site fidelity is there?

5. What factors limit nesting success?

6. What are survival rates of young in nest, post-fledged, immatures, and adults?

7. How significant is this (e.g. CAHA) breeding or wintering population segment to the state, region (middle Atlantic coast), or Atlantic coast wide population changes and trends?

8. What is the current level of ORV, pedestrian traffic, and leashed and unleashed pets in piping plover habitat?

\section{Adaptive Management Protocols}

Objective 1: To attain a nest exclosure design that protects eggs from predation and prevents harrassment and mortality of incubating adults by predators in accordance with the "Guidelines for the Use of Predator Exclosures to Protect Piping Plover Nests" in the Atlantic Coast revised recovery plan (USFWS, 1996).

Proposal: Several treatments may be tested for the same nest over time, as the purpose is to modify the exclosure design until the risk of mortality of eggs and adults is minimized, rather than to stick to one treatment until the nest is lost. The stewards will have to decide which designs make sense to try, based on the risk and the circumstances, and some plovers may refuse to incubate inside an exclosure of any design. Pre-construction evaluation, construction, and post-construction monitoring should be performed according the the Atlantic Coast revised recovery plan guidelines (USFWS, 1996). There are many exclosure designs in the literature, but the treatments we propose are

a) standard 3-m diameter circular exclosure of 5-cm welded wire fencing, staked with steel fence posts and roofed with bird netting (fig. 1-3).

b) Design $a$, but with 3-m long straight wings of exclosure fencing attached to opposite sides of the circle, to prevent predators from circling the exclosure (fig. 1-3).

c) Design $a$ or $b$, with a battery-powered electrified wire girdling the exclosure approximately $0.3-0.6 \mathrm{~m}$ from the ground, to deter predators.

d) No exclosure

A fifth "treatment" would be to remove a particular predator through hunting or trapping if it appears to be causing a problem. This treatment can be added to any of the above exclosure designs, and should be used with treatment $d$ if an exclosure has to be removed due to a nuisance predator.

Exclosures should be monitored with infrared 24-hour (h) time lapse videography, to determine number of predator encounters, predator response to the exclosure (including time spent at the exclosure, or near the nest if there is no exclosure), response of the adult plovers to the predator, and outcome of the encounter (survival of nest or adult). However, care must be taken to ensure the camera and its foundation does not serve as a perch for avian predators. If resources are an issue, the exclosure can be checked each day for signs of 
(A)

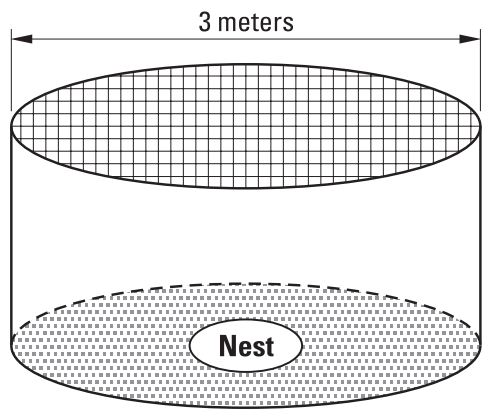

(B)

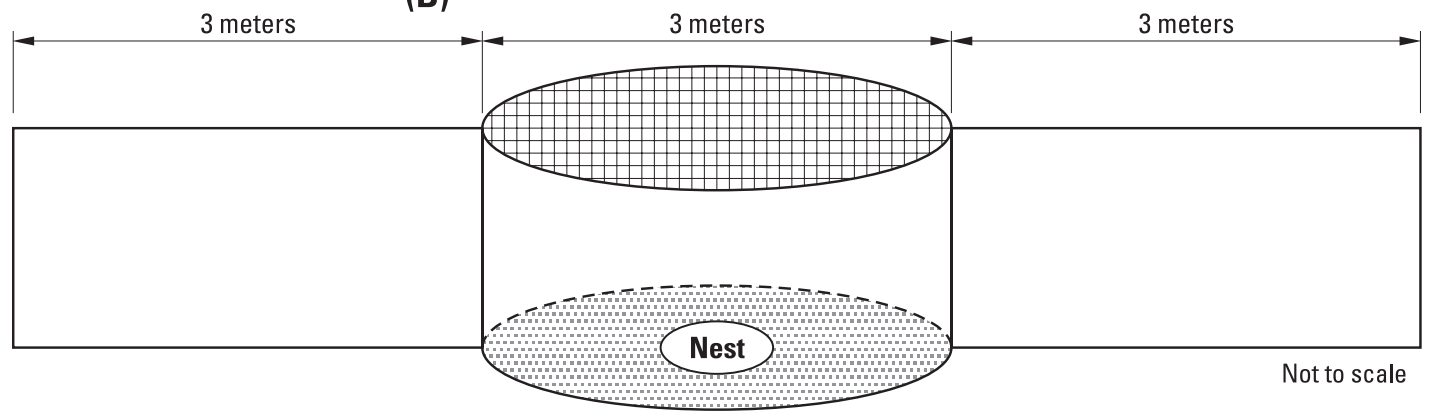

Figure 1-3. Proposed exclosure designs for piping plover nests at Cape Hatteras National Seashore, (A) standard design, (B) standard design plus 3-meter wings. White areas represent welded wire. Hatched areas represent bird netting. Stippled areas represent sand.

disturbance, and the camera only used if a problem becomes evident (but it should be used in any case when the expected hatch date is imminent). Qualitative results of changing the design can be inspected at first, but quantitative analyses may be conducted after several years of data are gathered (or the population size grows enough to permit it.

Objective 2: To compare disturbance rates, habitat availability and use, and the presence of potential predators among sites where different management options are being employed. Note that the decision about which management option to use should be based on providing the most protection possible to the population at a site. Reducing the protection to any degree below $100 \%$ should be a matter of discussion between the Park Service and the USFWS, and the NCWRC. The proposal below is therefore a protocol for data collection, rather than experimentation, and should be followed even if the same level of protection is used at all sites. If the protection level is ever changed, managers will then be prepared to gauge the effect of the change.

Proposal: Collect the following data at each site:

1. Recreation management strategy employed at the site

2. Number of territorial pairs

3. Number of pairs for which at least one nest was found

4. Number of eggs hatched/nest, number of chicks fledged/brood and chicks fledged/pair

5. Causes of egg, nest, chick, or adult loss, if apparent

6. Habitat use and activity budgets of adults (migratory, wintering, territorial establishment, and breeding periods) in 5 or 10 minute (min) periods, using a focal animal method (Altman, 1974).

7. Habitat use and activity budgets of chicks in 5 or 10 min periods, using a focal animal method (Altman, 1974)

8. Habitat availability, using aerial photos and transects 
9. Terrestrial and benthic prey abundance and biomass

10. Number of potential predators and disturbance sources within $100 \mathrm{~m}$ of adults, nests, and broods Habitat use should be measured both as:

a) Proportion of daily surveys in which an adult or brood was in a particular habitat when first located

b) \% time spent in a particular habitat during 5-minute behavioral observations, where habitat use is recorded on a tape and later sampled every 10 seconds. Disturbance events, including disturbance source, and duration of the disruption of normal activity should be recorded during these observations.

Weather and tidal stage should be recorded whenever behavior is measured.

When measuring habitat availability, large-scale features (such as MOSH and non-MOSH "upland" habitat) can be classified from aerial photos taken during the relevant time of year, and smaller-scale features can be measured as \% width along randomly-placed transects perpendicular to the shoreline. These transects can be measured once/month, except wrack should be measured once/week due to the variability in its availability.

Terrestrial prey can be sampled by placing sticky traps in different beach zones. Benthic prey can be sampled with cores.

Objective 3: To determine the necessary buffer distances to prevent disturbance to breeding and non-breeding birds by pedestrians, ORVs, kites, dogs, and boats.

Proposal: As with objective 2 above, this is a protocol for data collection that will assist managers in assessing the effects of changing buffer distances, if a management option involving buffer zones around habitat and/or nests (as opposed to site closure) is employed. Collect data as per Objective 2, but record the buffer distance being employed around whatever feature is relevant to the focal animal at the time of the observation, the type of feature buffered (e.g., MOSH for foraging adults, nests for incubating adults, center of brood territory for chicks), the distance from the focal animal to the nearest buffer zone boundary, and a code to indicate if the bird was outside of a protected area. Recommendations for initial buffer sizes and protocol for changing them are given below (see "Management Recommendations").

Objective 4: To determine the effectiveness of predator removal on nest success, breeding success, and site fidelity.

Proposal: Attempt to remove all potential mammalian nest and brood predators from all plover habitat prior to the breeding season using various trapping methods, recording catch/unit effort for each method. Remove problem avian predators as they occur. Set up 24-hour predator bait stations near (but not in) plover habitat, with motion sensitive cameras to monitor encounters with predators. In addition, record number of potential predators within $100 \mathrm{~m}$ of nests or broods during daily monitoring. Count predator tracks along randomlyplaced transects perpendicular to the shoreline in plover habitat. Determine the relationship between trapping success and predator abundance indices, and between predator abundance indices and proportion of nests lost to predators, breeding success, and adult movements within the breeding season (especially between nest attempts).

\section{Additional Research to Address Management Goals}

Question 1: What are the vital rates of the breeding population of plovers, which one (if any) currently regulates the population?

Proposal: Catch and individually color-mark all adults and chicks at CAHA, over several years. Attach radiotags to nearly-fledged chicks so that survival and movement during post-fledging can be monitored. Calculate annual survival of adults and young, as well as emigration and immigration rates, and population growth rate. This study will only be informative if the protections recommended in these protocols are enacted. Without such protection, we do not predict an appreciable change in vital rates or population growth.

Question 2: How different are day and night behaviors and habitat use? 
Proposal: Repeat the behavioral observations detailed above under objective 2, using night-vision optics. If habitat areas are closed at night to recreation as per our recommendations below this should be noted during data collection.

Question 3: How significant is ghost crab predation, and how may it interact with predation by other animals?

Proposal: Use the infrared videography technique detailed above to record encounters of ghost crabs with nests. Record frequency of ghost crab encounters with adults and chicks during behavioral observations. If ghost crabs are observed to take eggs or create a burrow near a nest, record whether the nest was first disturbed by another predator.

Question 4: What is the carrying capacity of Cape Hatteras National Seashore for piping plovers in the breeding period, and how is the estimate affected by recreational use of the beaches, and by overwash?

Proposal: Collect aerial photos and ground truth points in plover habitat during the territory-establishment period (late April to early May). Classify nesting and foraging habitat, and delineate ORV-use zones and overwashes. Calculate expected carrying capacity based on values of birds/ha nesting habitat from Cohen, 2005. Further estimate carrying capacity as if ORV-zones were unusable, or less usable, and without overwash areas.

Question 5: How much site tenacity is there for nonbreeding birds, and how much movement is there among subpopulations in the winter?

Proposal: The first question can be addressed simply by monitoring use of locations using GPS devices and applying modifications of Markov models (see Erwin and others, 1998). The second should be addressed by color-marking or radio-marking plovers during the wintering period (late Nov.-Feb.) and following their movements.

\section{Management Recommendations}

We provide three management options for piping plovers and their habitat, presented in order of increasing predicted negative effect. The protections described herein are based on the recommendations in the recovery plan (USFWS, 1996), but are intended to be applied in addition to the protections recommended in the recovery plan, wherever this document provides stronger protection or more intensive monitoring (table 1-2). Since the plover habitat at CAHA is dynamic and subject to change given weather, tides, and the continuous coastal processes of sediment erosion and accretion, some of the recommendations may become inapplicable for certain sites, or new sites may form that provide suitable plover habitat.

\section{Option A: Highest Degree of Protection}

\section{Recommendations:}

1. Close all potential piping plover nesting, roosting, and foraging habitat (ocean and soundside intertidal zone and other MOSH, ocean backshore, dunes, dry sand flats, overwashes and blowouts) to all recreation, 24 h/day year round, at Bodie Island Spit, Cape Point, South Beach, Hatteras Spit, North Ocracoke, South Ocracoke (figs. 1-4-1-8).

2. Throughout the remainder of CAHA, protect a zone of ocean backshore at least 10-m wide and running the length of the site from recreation. This zone should be adjacent to the toe of the primary dune wherever a primary dune exists (i.e., recreation should be restricted to a corridor between the mean high tide line and the edge of the zone of protected backshore). This will reduce the effects of recreation on nesting habitat throughout CAHA and increase the likelihood that plovers will colonize sites outside of the spits, once the carrying capacities of the spits have been attained. Management should revert to Option A item 1 if plovers are documented in an area. 
3. A 50-m buffer zone of signed, stringed symbolic fencing should be placed around all nests to reduce the risk of damage by essential vehicles or monitors. CAHA should coordinate with agencies that have jurisdiction over the water to keep boats outside of this buffer zone, where applicable (the Park boundary is approximately $50 \mathrm{~m}$ from the shoreline on the Sound side).

4. Essential vehicles should only enter restricted areas subject to guidelines in the Essential Vehicles section of Appendix G of the Revised Recovery Plan for the piping plover (USFWS, 1996). Essential vehicles should drive in the intertidal zone at speeds not to exceed 10 miles per hour $(\mathrm{mph})$, whenever possible. Essential vehicles should be accompanied by a plover monitor whenever possible.

5. In the nonbreeding season, and prior to nest-hatching in the breeding season, plover monitors may conduct their activities by ORV. They should drive only in the ocean intertidal zone, but avoid the wrackline, at speeds not to exceed $10 \mathrm{mph}$. If this is not possible, monitoring by ORV should not be conducted at that time. When a courting pair or a set of courtship scrapes has been located, the monitoring vehicle should not pass through the prospective territory until the nest has been discovered. The vehicle should be parked at least $200 \mathrm{~m}$ from the suspected center of territorial activity (farther away if the area of scraping is more extensive), and the rest of the monitoring in that area should be conducted by foot. Once the nest is discovered, ORV-based monitoring may resume until the nest is lost and the pair begins attempting to renest, or the nest hatches. In case of hatch, if an ORV is used it should be parked at least $1000 \mathrm{~m}$ from the last known brood location, and the rest of the monitoring conducted on foot until the brood is at least 35 days old.

6. Continue trapping of potential nest and brood predators prior to the onset of the breeding season with the goal of removing all potential mammalian predators from the site, including the removal of all foxes from Hatteras Island and the prevention of their spread to Ocracoke Island. Removal of avian predators should be done by targeting problem individuals (Boarman, 2003) within plover breeding habitat in the presence of a trained monitor, and avian predation can be further controlled by enforcing proper trash disposal and anti-feeding regulations throughout CAHA (Boarman, 2003). Consult with a plover monitor familiar with nest and/or brood locations when trapping during the breeding period, to avoid disturbing nests or broods. Trapping should be done by USDA Wildlife Services or trappers approved by USDA who have experience with the species being trapped, under the guidance of Department of the Interior Animal Care and Use guidelines.

7. Protect nests with exclosures according to the adaptive management protocols detailed above. Monitor the exclosures for sign of harassment of adults by predators, or evidence of adult mortality.

\section{Predicted effects:}

There will be almost no risk of direct recreation-related injury, mortality, or disturbance to piping plovers within the focal sites mentioned, and no recreation-related habitat loss at those sites under this management option. The risk of mortality or disturbance to adults, nests, or broods, attraction of predators to plover habitat, degradation of the wrack line, and alteration of the beach profile is very high outside of the focal sites, although we don't predict breeding plovers to use the rest of CAHA until the populations at the focal sites increase. Visitation to other areas of CAHA may attract potential plover predators such as gulls that may then enter plover habitat at the focal sites. Essential vehicle use of plover habitat and ORV-based monitoring entail slight risks of a nest being crushed if it is laid in a previously unsuspected location, and death or injury to an adult bird or chick. Predator trapping may result in disturbance to adult plovers or broods, or loss of chicks if the trappers are not cognizant of the location of the birds. Nest exclosures will cause disturbance to adults during placement, entail a slight risk of damaging eggs during placement, and may result in adult mortality or nest losses if a particular predator learns to hunt at them.

\section{Option B: Moderate Protection}

\section{Recommendations:}

1. Close all potential piping plover nesting, roosting, and foraging habitat (ocean and soundside intertidal zone and other MOSH, ocean backshore, dunes, dry sand flats, overwashes and blowouts) to 
ORV traffic, $24 \mathrm{~h} /$ day year round, at Bodie Island Spit, Cape Point, South Beach, Hatteras Spit, North Ocracoke, South Ocracoke (figs. 1-4-1-8).

2. CAHA should coordinate with agencies that have jurisdiction over the water to keep boats outside of $50 \mathrm{~m}$ from the habitat at the above sites, where applicable.

3. Pedestrians may be permitted within a narrow walking and sunbathing corridor extending landward from the mean high tide line, from sunrise to sunset, on the oceanside only. Prohibit recreation at these sites from sundown to sunrise. Pets, kite-flying, frisbee and ball-playing, fireworks, wildlife feeding and trash disposal should be prohibited. This corridor should be narrowed or eliminated over all or part of its length if necessary to prevent disturbance to plovers. The pedestrian corridor should be narrowed or closed to provide a recreation-free buffer zone $50 \mathrm{~m}$ wide (or the distance recommended for other avian species using the area, whichever is greatest) around all areas of MOSH, all overwash corridors, and any place that courtship behavior or scrapes are observed. The buffer zones should immediately be widened to $100 \mathrm{~m}$ any place that disturbance of plovers by recreation is observed, then to $200 \mathrm{~m}$ if disturbance persists. Furthermore, the corridor should be narrowed or closed to provide a recreation-free zone in the ocean backshore at least $10 \mathrm{~m}$ wide and running the length of the site, wherever backshore habitat occurs. Once narrowed or closed, the recreation corridor should not be widened or reopened without the approval of the USFWS and North Carolina Wildlife Resources Commision (NCWRC) on a case by case basis.

4. Throughout the remainder of CAHA, narrow the current 50-m ORV corridor such that a zone of ocean backshore at least $10 \mathrm{~m}$ wide and running the length of the site is free of ORV traffic. This zone should be adjacent to the toe of the primary dune wherever a primary dune exists (i.e., recreation should be restricted to a corridor between the average high tide line and the edge of the zone of protected backshore). This will reduce the effects of recreation on nesting habitat throughout CAHA and increase the likelihood that plovers will colonize sites outside of the spits, once the carrying capacities of the spits have been attained. Management should revert to items 1 and 2 of Option B if plovers are documented in an area.

5. When a nest is discovered, prohibit pedestrians from approaching within $50 \mathrm{~m}$ of the nest (USFWS, 1996), or the distance recommended for other avian species if any of them are nesting nearby (whichever is greatest), using stringed symbolic fencing. Adjustments of the fencing should be limited to those needed to protect the incubating adults from disturbance. This buffer zone should be expanded on a nest-by-nest basis if monitors determine $50 \mathrm{~m}$ to be inadequate to prevent disturbance to a particular pair. The first time disturbance is observed, the buffer zone should be expanded to $100 \mathrm{~m}$, then to $200 \mathrm{~m}$. If an experienced monitor is unavailable to alter the buffer area, the beach should be closed for $200 \mathrm{~m}$ around the nest until the fence can be restructured. If the tide line is within the buffer zone, close the beach to recreation $50 \mathrm{~m}$ on either side of the nest, expanding this distance if disturbance is observed, as above.

6. Within one week of the expected hatch date of a nest, prohibit ORVs and boat landings in all plover habitat within 1,000 $\mathrm{m}$ of the nest. After hatch, the closed area should be 1,000 $\mathrm{m}$ on either side of the brood's center of activity. Within this zone, at the Park's option pedestrians can pass below the tide line at a walking pace and not stop, if a trained monitor is observing the brood. Alternatively, the brood zone can be shut down to all recreation. We recommend the latter until the plover population size has increased to at least 10 pairs. Maintain this protection until it is certain that all chicks have fledged or are 35 days of age.

7. Enact recommendations 3-6 detailed above under Option A.

8. Buffer zones that were expanded to protect nests may be returned to their pre-nest size after the nest is lost if, after 1 week of monitoring, it is determined that the pair is not attempting to renest in the area and that no breeding colonial waterbirds, oystercatchers, sea turtles, or seabeach amaranth occurs within the expanded buffer zone. Such modifications should be made only with the consent of the USFWS and NCWRC, on a case by case basis. 
9. Portions of the pedestrian corridor that were narrowed or closed according to Option B item 3 during any part of the year may be reopened to recreation, once piping plovers have left the area, provided that no colonial waterbirds, oystercatchers, sea turtles, or seabeach amaranth occur in the closure and CAHA obtains permission from the USFWS and NCWRC on a case by case basis.

\section{Predicted effects:}

Adults are likely to be disturbed at a low level by pedestrians at the focal sites, and with less probability adults or nests may be harmed. Nests may be vandalized or otherwise damaged before they can be found and protected. The risk of all of these effects occurring is very high outside of the focal sites, although we don't predict plovers to use the rest of CAHA until the populations at the focal sites increase. Potential predators such as gulls may be attracted to the focal sites by the presence of pedestrians, but this effect is likely to be stronger outside the focal sites. Outside of the focal sites, ORV traffic may lead to destruction of the wrackline and alteration of the beach profile. Outside of the focal sites pets may harrass or harm plovers or their nests before management is put into place. Chicks are at risk of being crushed by pedestrians if they move to a previously unsuspected location, or if CAHA opts to allow pedestrians to walk through the brood zone. A benefit of allowing some pedestrian recreation adjacent to piping plovers is that there will be more opportunity to foster positive public attitudes toward plovers and plover management through outreach and education. Potential negative effects of essential vehicles, ORV-based monitoring, trapping, and exclosures are the same as for Option A.

\section{Option C: Minimum Protection}

\section{Recommendations:}

1. Restrict all recreation to a 50-m corridor on the ocean side, from the mean high tide line landward, from sunrise to sunset, $24 \mathrm{hr}$ /day year round at Bodie Island Spit, Cape Point, South Beach, Hatteras Spit, North Ocracoke, South Ocracoke. This corridor will be narrow enough to provide adequate nesting, foraging, and roosting habitat for piping plovers given the size and configuration of the habitat at these sites in 2005. Alteration of the habitat by storms or other natural processes may require a narrowing of the corridor, and at a minimum no recreation should be permitted in bay intertidal zone or other MOSH (except ocean intertidal zone), dunes, dry sand flats, overwashes and blowouts, and a 10-m wide strip of ocean backshore. Closure or narrowing of the corridor should occur as per the recommendations in Option B, item 2. Once narrowed or closed, it should not be widened or reopened without the approval of the USFWS and NCWRC, on a case by case basis. At the Park's option, ORVs may be allowed into the corridor only in escorted convoys, similar to the Hatteras Spit experiment in 2005. Prohibit recreation at these sites from sundown to sunrise.

2. CAHA should coordinate with agencies that have jurisdiction over the water to keep boats outside of $50 \mathrm{~m}$ from the habitat at the above sites, where applicable.

3. At the aforementioned sites, pets, kite-flying, frisbee and ball-playing, fireworks, and wildlife feeding and trash disposal should be prohibited. The speed limit should not exceed $10 \mathrm{mph}$.

4. Enact recommendations 4-9 under Option B above.

\section{Predicted effects:}

Adults are at risk of disturbance by pedestrians and recreational ORVs and boats at the focal sites, although this risk is lower than under current management because the closures are more extensive. Adults are at risk of being harmed, and nests may be damaged before they are found and protected. These effects would be reduced with the escort option. The wrackline is likely to be degraded by ORV traffic and the beach profile altered by vehicle passage, even with an escort option. Enforcement of restrictions on pets and other activities will be more difficult than under Option B, increasing the risk of harrassment or harm to plovers. Young chicks may become trapped in ORV ruts. Attraction of potential predators such as gulls to breeding areas would be less than under current management to the extent that trash disposal and wildlife-feeding rules are enforced. Effects of recreation outside the focal areas and potential effects of essential vehicle use, ORV-based monitoring, trapping, and exclosures are the same as for Options A and B. 
Table 1-2. Comparision of recommendations in the Atlantic Coast piping plover revised recovery plan (1996) and this Protocol.

[>, greater than; m, meters, ORV, off-road vehicle; USFWS, U.S. Fish and Wildlife Service]

Recovery plan recommendation

Protocol recommendation

Symbolically fence areas on April 1 that receive high levels of human disturbance. Allow vehicles to pass through an ORV corridor between nesting habitat and the tide line if conditions permit.
Close or enact buffer zones around habitat by March 15, or sooner for nonbreeders. Allow pedestrians and/or ORVs in a corridor between the nesting habitat and the tide line if conditions permit.
Keep pets on a leash and outside of fenced areas. Prohibit pets if leash laws are difficult to enforce. Prohibit kite-flying within $200 \mathrm{~m}$ of breeding plovers. Prohibit fireworks on breeding beaches after April 1.
Prohibit pets, kites, ball playing, trash-disposal, wildlfefeeding, kites, and fireworks from all sites being used by plovers, during any part of the year.
Prohibit ORVs within $1000 \mathrm{~m}$ of broods, to be modified based on historical or current data of brood movements, provided the buffer is $>100 \mathrm{~m}$ and all broods are monitored at a frequency to be agreed upon by the USFWS and state management agencies.
Maintain 1000-m recreation free zones around brood, except pedestrians may be permitted to walk through a brood territory below the tideline under the supervision of a trained plover monitor.
Monitoring of habitat twice per week prior to May 1, and at least 3 time per week thereafter. Monitor once per week during the nonbreeding period in each of 3 months (one month in the fall migration, wintering, and spring migration periods).
Monitor 3 times per week after April 1, for breeding birds. Monitor nonbreeding birds 3 times per week from July 1 to May 30, also recording the onset of breeding behaviors.
Symbolically fence 50-m buffer zones around all nests, increasing the distance if it appears necessary. Truncate the buffer zone at the tide line, but monitor to ensure that this provides adequate protection from disturbance.
Follow recovery plan guidelines, except close areas to recreation if the nest is near the tide line. Increase the buffer distance to $100 \mathrm{~m}$ the first time recreational disturbance is noted, then to $200 \mathrm{~m}$ if necessary.
Use nest exclosures whenever predation is perceived to be a problem, but modify or remove the exclosure if it seems to be increasing the risk of nest loss.
Follow recovery plan guidelines, modified by adaptive management protocols to examine the effect of exclosure design. Remove all mammalian predators from plover habitat and all foxes from Hatteras Island. Remove individual avian predators from plover habitat as they become a problem. Monitor the effect of ghost crabs on nest and chick survival. 


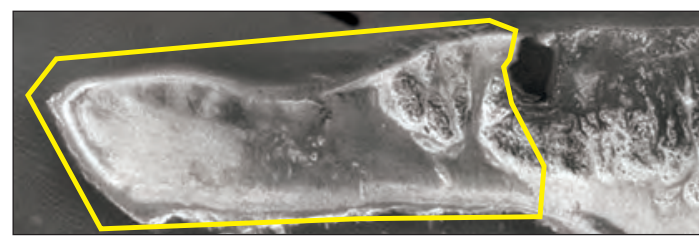

Figure 1-4. Hatteras spit. Yellow line indicates area within which recommended closures and restrictions should occur under management options $A, B$, and C.

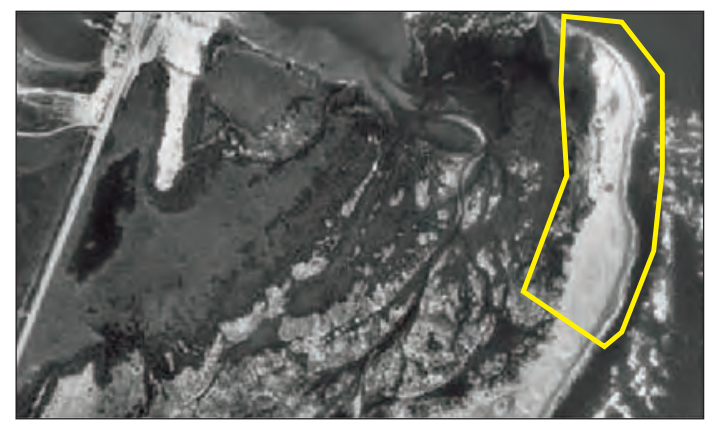

Figure 1-6. North Ocracoke. Yellow line indicates area within which recommended closures and restrictions should occur under management options $A, B$, and $C$.

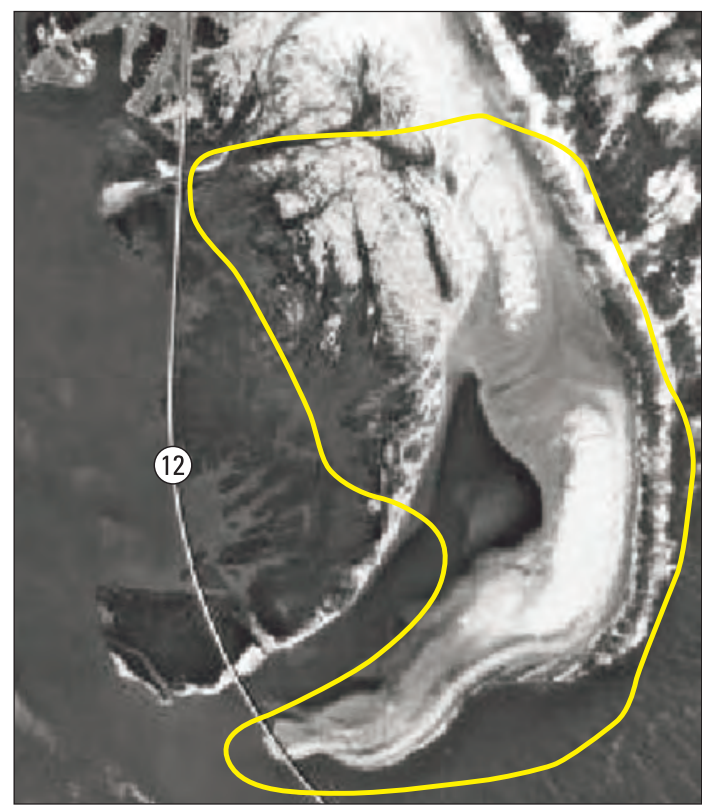

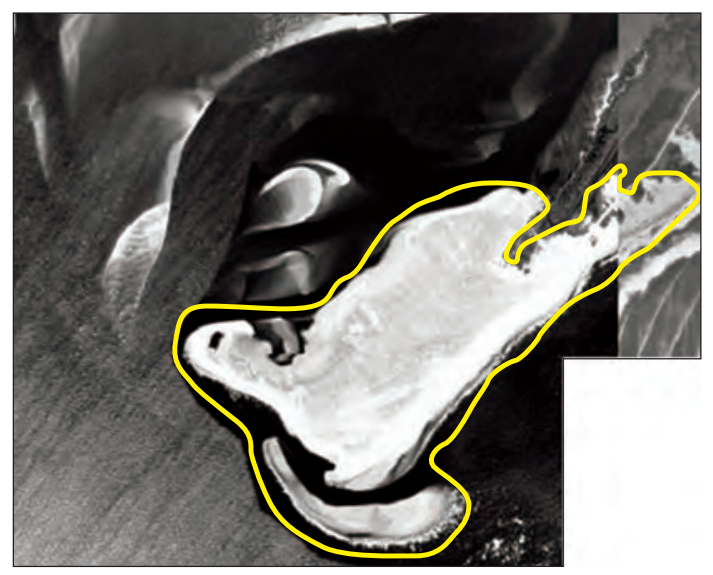

Figure 1-5. South 0 cracoke. Yellow line indicates area within which recommended closures and restrictions should occur under management options $A, B$, and $C$.

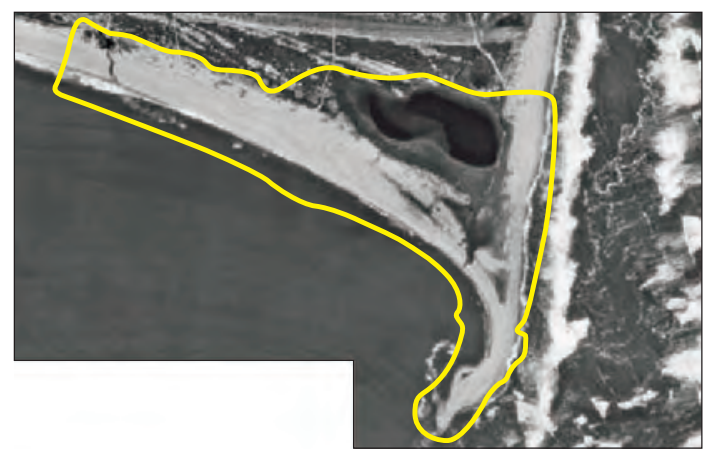

Figure 1-7. Cape Point and South Beach. Yellow line indicates area within which recommended closures and restrictions should occur under management options $A, B$, and $C$.

Figure 1-8. Bodie Island Spit. Yellow line indicates area within which recommended closures and restrictions should occur under management options A, B, and C. 


\section{Additional Recommendations}

\section{Green Island}

Close Green Island to all human activities, including boat landings, after April 1st. This closure is intended to increase the chances that plovers will colonize the site. After breeding activity for piping plovers and other waterbird species has ceased, restrictions can be lifted, except habitat such as MOSH used by protected species in the nonbreeding period should be protected from recreational use by a $50-\mathrm{m}$ buffer zone.

\section{Protection of Habitat Created as a Result of Storms and Other Natural Coastal Process}

Overwash and breach-created landscape features are a normal part of the barrier-island system, but armoring or renourishing the shoreline and filling or stabilizing inlets to protect human structures is a common practice that prevents such features from forming and alters patterns of vegetative succession (Dolan and others, 1973). Piping plovers and other species may exhibit preference for such dynamic features for roosting, nesting, and foraging, and hindering their formation may indirectly effect a local population by decreasing the carrying capacity of the landscape for these animals (Goldin and Regosin, 1998; Nicholls and Baldassarre, 1990; Elias and others, 2000; Cohen, 2005). Thus, we recommend allowing natural processes to occur unimpeded whenever feasible. Newly-created inlets and overwash areas should be afforded the same level of protection from disturbance that we detailed above for historical plover breeding sites at CAHA, at least until their use by plovers and other species can be assessed and the USFWS can determine whether alteration of the habitat would lead to effects on plovers or their prey in the present or future.

\section{Monitoring}

The first goal of monitoring pertains to collecting information on population size and reproduction. Managers can use this information to protect birds and habitat to further the ultimate goal of recovering the population. The specific objectives are to determine the number and location of territorial pairs, the number and location of nesting pairs, the number of nest attempts, reproductive rate (chicks fledged/nesting pair), sources of nest and chick mortality, and size and location of nonbreeding flocks. The second goal of monitoring is to provide immediate information on potential threats to flocks, pairs, nests, or broods so that managers can act quickly to protect the plovers.

\section{Nest and Chick Survival}

Except at Green Island, search sites for plover pairs at least three times/week from March 15 until the first nest is laid. Record locations where territorial behavior, courtship, and mating behavior are observed on a map, with the date of observation. Enlarge protected areas where plovers are observed prospecting for territories outside of the symbolic fence.

After April 20th, search for nests at least once every two days, except at Green Island where monitoring should occur as logistics permit. Keep a small disposable camera on hand in case evidence of a take is encountered (do not leave the camera in a truck for days or the film may be ruined by hot weather). Check known nests at least once every two days. Prior to incubation the nest may be approached so that the eggs can be counted, and potential disturbances to the laying schedule can be assessed. After incubation commences, observe the incubating bird with optical equipment from outside the symbolic fence. If the bird cannot be seen on the nest, the nest may be approached. Whenever a nest is checked, we recommend that a minimum of the following information be recorded:

1. Date and time of nest check 


\section{Nest number}

3. Geographic coordinates of the nest location when it's first found, recorded with a GPS unit in UTM coordinates and NAD 83. You should be able to locate the nest in open beach with a GPS even if markers are gone or not used. Colored flagging may be tied to the symbolic fence, $50 \mathrm{~m}$ if possible but at least $10 \mathrm{~m}$ from the nest (for closures truncated at the tide line), to assist other stewards in relocating the nest. Nest markers should not be placed in the sand.

4. Habitat (see glossary)

5. Number of eggs (if the bird is not flushed, record that the bird was incubating and the number of eggs was not observed)

6. Status of the nest (laying, incubating, lost, abandoned, hatching, hatched)

7. The presence and behavior of the adults [incubating eggs, shading eggs, resting, foraging, disturbed (record source), territorial flight, territorial encounter, distraction display or other defensive behavior toward predator or pedestrian, courtship, other behavior (describe)]

8. The presence of potential predators, humans, pets, or ORVs within $100 \mathrm{~m}$ and locations relative to the nest

9. Evidence (i.e., trails) of potential predators, humans, or ORVs within the posted areas, including distance to the nest.

10. Approximate distance to tide line, in meters

11. Suspected cause of nest loss, if apparent

Items 7-10 can help managers to assess threats to the nest. Once a nest hatches, observe the brood at least once every two days. Broods should be observed with optics from a distance unlikely to cause disturbance ( $20 \mathrm{~m}$ greater than the maximum distance at which monitoring activities are found to disturb broods at CAHA). Unlike other species where banding and marking of young is permitted and recapture allows for robust statistical models to be applied, piping plover marking is generally not permitted by the Region 5 USFWS Recovery Plan. Therefore, "probability of fledging" is always more uncertain for a nest in this species than in many others. We recommend a minimum of the following information be recorded at each brood check:

1. Date and time of brood check

2. Nest/brood number

3. Location of brood (mark on a map or record with a GPS unit)

4. Habitat (see glossary)

5. Number of chicks

6. Brood age (this is known from other data on hatch date)

7. Brood behavior [foraging, resting/brooding, disturbed (record source), other]

8. The presence and behavior of the adults [foraging, brooding, resting, disturbed (record source), territorial flight, territorial encounter, distraction display or other defensive behavior toward predator or pedestrian, courtship, other behavior (describe)]

9. The presence or evidence of potential predators, humans, or ORVs within $100 \mathrm{~m}$ and their location relative to the brood

10. Cause of chick loss, if carcass is found and source of mortality is apparent

A nest or brood that appears to be at risk should be reported to a manager from the field if possible, but otherwise upon return from the field. All data from the nest or brood monitoring sheet should be provided to the manager. 


\section{Nonbreeding Plovers}

Monitoring of nonbreeding plovers should be aimed at estimating the size and distribution of the population at CAHA during migration and wintering, determining the types of habitats used by nonbreeding plovers, and identifying sources and rates of mortality and disturbance to nonbreeding plovers. Bodie Island Spit, Cape Point and South Beach, Hatteras Spit, North Ocracoke, and South Ocracoke should be surveyed at least 3 times per week from July 1 to May 30 for nonbreeding plovers. All sites should be surveyed on the same day to the extent possible, to reduce double-counting of individual. Green Island and other shoal islands should be surveyed when practicable, especially when no birds are apparent at the barrier island sites. CAHA should coordinate with Cape Lookout National Seashore to conduct simultaneous surveys or receive survey data from Portsmouth Island during the winter, especially when no plovers are seen at South Ocracoke, since based on past banding data wintering birds may move across Ocracoke Inlet. Additionally, CAHA should coordinate monitoring of winter birds with NCWRC nonbreeding surveys. The following data should be collected during nonbreeding bird surveys:

1. Date

2. Start and end time of survey at each site

3. Weather variables [air temperature, wind speed and direction, visibility, $\%$ cloud cover (estimated by eye), precipitation $(0=$ none, $1=$ light, $2=$ heavy $)]$

4. Tidal stage (hours after high tide)

5. Number of birds

6. Habitat (see glossary)

7. Site management where the birds are seen (e.g., ORV Closure

8. Behavior of the majority of birds in the flock [foraging, resting, disturbed (record source), other]

9. Whether territorial (T) or courtship (C) behavior is observed, or not (0)

10. If the bird/flock moves during a survey, record distance moved in meters, and cause of move if apparent

11. Number of pedestrians, pets, ORVS, gulls, other potential disturbances within $100 \mathrm{~m}$ (estimated by eye) of the bird or flock

12. Band combination of any banded birds, using the reporting protocols already developed by CAHA staff for band color and location.

If there appear to be multiple distinct flocks at a particular site, the observer should record data for each flock on a separate line on the data sheet, since flocks may often use different habitats or exhibit different behaviors. The above data will assist managers in determining the abundance and distribution of nonbreeding birds. Furthermore, it will help to answer questions about the prevalence of threats to wintering birds and the response of the birds to those potential threats. 


\section{Law Enforcement}

Nests or broods deemed to be at particular risk of vandalism should not be left unattended. Lay volunteers may be used to sit within viewing distance of a nest or brood during daylight hours, to report problems. Monitors should carry radios or cellular phones. If a monitor observes a potential infraction of the law that threatens a plover adult, nest, or brood, the relevant law enforcement personnel should be immediately contacted from the field, if possible, and the monitor should maintain visual contact with the nest or brood in danger. This will allow the monitor to provide the most accurate description possible. If the monitor is not able to contact enforcement immediately, or if the monitor risks endangering him or herself by remaining at the site, the monitor should leave the field as soon as possible and contact law enforcement.

If the scene of a past violation is discovered (such as a nest destroyed by a pedestrian), the scene should be left intact and the following information should be recorded:

- Date and time

- Weather and tide conditions

- Location (Use a GPS unit to record the location). Plant a survey flag or other marker to assist in relocating the site. This should be a colored, easy to see marker.

- Nest number if given

- Number of adults, eggs, and/or chicks involved

- Behavior of adults and/or chicks

- Condition of adults, eggs, and/or chicks

- Hand-drawn map showing adult, nest, and/or brood, symbolic fence line, predator, pedestrian, and/or ORV trails, other evidence, and nearby landscape features (e.g., tide line, dune line). If possible, use gridded paper so map scale can be indicated.

- Photographs of the evidence

The relevant law enforcement personnel should be contacted as soon as possible and provided with a copy of the incident record. While gathering of information by a lay person may compromise the scene to some degree, the ephemeral nature of evidence in beach environments requires immediate collection of some basic data.

\section{Reporting Procedures}

The data collected in the field have many potential uses and applications. For nesting location data, GPS locational information needs to be conveyed as quickly as possible to Resource Management staff in order to implement protection measures. Similarly, witnessing violations of closure areas or other illegal activities needs to be conveyed to Law Enforcement staff as soon as possible. If violations of federal or state regulations are confirmed, notification needs to be made to the U.S. Fish and Wildlife Service-Raleigh Field Office, the National Marine Fisheries Service, and the North Carolina Wildlife Resources Commission as appropriate.

The field data should be collected in two forms: in field books as narrative accounts, and on field data forms developed in conjunction with other partner agencies, scientists and managers. Field forms should be quality checked by an independent reader, comparing field notebooks and forms where appropriate (see section below). When verified, the data should be electronically entered, analyzed where needed, summarized in reports in text, tabular and graphic form, and submitted to both CAHA administrative personnel and other cooperating agency personnel and other scientists and managers as requested. Reports should be available both in electronic form (pdf preferred) and in limited numbers of hard copy. 


\section{Data Management}

\section{Raw Data Collection}

Field data sheets should include, at a minimum, the date, the reference location (GPS and usually a code number), a point or specific area, and observer name or initials. Because of the large amount of data included in these different data collection efforts, we strongly urge that all individuals engaged in data collection be trained in advance of the actual data collection period. Regardless of how clear a field form appears to be, questions always arise about how to record certain types of data. In addition, where counts of birds are recorded, we strongly urge that two observers keep independent records. Variation due to observer differences has been shown to be a major source of error (Sauer and others, 1994).

\section{Data Entry}

Because the National Park Service (as well as other agencies) has determined that Microsoft Access will be the official database management software in the monitoring programs, we recommend it as the primary management tool. In some cases, Excel spreadsheets may be used since this is what the cooperators/contractors often provide. However, conversion of Excel to Access is not difficult and the structure of the tables is quite similar.

For the majority of the bird data sets, the data are entered directly from field forms into Microsoft Access, a relational database. One advantage of Access includes efficiency, because many fields of data (location, physical parameters) need not be reentered on each successive survey, and flexibility in presentation. Links can be made among tables of physical parameters, nesting rate estimate, hatching success, etc.

\section{Metadata}

The metadata are best structured as separate components as the resource and scientific community needing different aspects of the data are quite different. Quality assurance and quality control are best maintained by having the field data reviewed and entered into the database on the same day it is collected. Two individuals should first review the data to reduce error propagation. Generally it is best to have the person collecting the data also doing the data entry, followed by having a second person compare the computer printout with the original field sheets. This second step can be done at a later date to reduce fatigue on field days.

\section{Data Storage}

Field data sheets should be stored in a safe, low-fire-risk location in or near the NPS Headquarters in Manteo. Upon entry into a PC's electronic Access database, an extra copy of the database should be generated on a separate portable hard drive, or on CDs which then should be maintained in a separate building. If a computer network is available at the site, the files can be more easily transferred electronically to other PC sites, rather than having to physically transfer media between locations. Security demands by the NPS may require extra steps in the data management outlined here.

\section{Data Analysis Techniques}

The methods for analyzing the data will vary greatly depending upon the question and the level of analysis of interest. Excellent statistical support and advice is available both at the USGS Patuxent Wildlife Research Center (Drs. Jim Nichols, James Hines, John Sauer, William Kendall, Michael Runge, and Jeff Hatfield) and at North Carolina State University (Dr. K. Pollock associated with the North Carolina Cooperative Wildlife Research Center). Biologists at CAHA should consult with one or more statisticians whenever statistical analyses are to be conducted. Many population and metapopulation models are already available online from Patuxent (see http://www.pwrc.usgs.gov), but usually these require some discussion with statisticians beforehand. 


\section{Education and Outreach}

Public education.-While the strict protections detailed above are necessary to recover the plover population at CAHA, it will be important to engage the public at all times while implementing these protocols. Long-term sustainability of plover recovery at CAHA will depend on the cooperation of the public that uses CAHA. Area closures and restrictions, and the reasons for each of them, need to be made plain. Continue posting all symbolic fence lines with signs that clearly indicate the species being protected. Post signs detailing plover biology and the reasons for protecting the species at points where visitors are likely to first encounter restricted areas.

Provide visitors with postcards and informational brochures that contain information on plovers and the biological and legal reasons for their protection at CAHA, as well as details on how closures will be used to better inform management in the future such that restrictions may possibly be eased. Interpretive walks in which visitors are guided to places to watch breeding and nonbreeding adults and broods through a spotting scope can also be a useful outreach mechanism, since untrained visitors will likely never otherwise see this species due to its cryptic coloration and inconspicuous behavior. Teaching the public to value plovers as part of the beach-going experience is the most important management activity that CAHA can undertake.

Advertise plover protection efforts and management successes in local papers and magazines and write educational articles for these outlets. Gain the confidence of a skilled writer/reporter in what you are doing. Ask that all articles that reporters write be checked by a manager or biologist so that corrections can be made if errors are found. Issue press releases detailing closures and other restrictions during both the breeding and nonbreeding seasons. Provide these press releases to local officials, the local press, local marinas, shops, special interest groups, etc.

Staff training.-Provide training to all CAHA staff including sign crew, patrol, maintenance crews, etc. on behavior and monitoring techniques for both nesting and wintering plovers. This training should also include plover identification, safe vehicle operations within plover habitat and limiting activities in habitat.

Plover monitors themselves need to have a subset of skills and knowledge before entering the field independently. These ideally include:

1. Ability to identify the adults, nests, and young of all protected species by sight, sound, and track evidence

2. Ability to identify breeding and nonbreeding behaviors by sight, sound, and other sign (e.g., nest scrapes, distraction displays)

3. Ability to observe adults, nests, and young of each species through optics and to record data without causing disturbance

4. Familiarity with the CAHA protocols for management and protection of each species

5. Basic knowledge of the laws protecting each species

6. Understanding of the process for dealing with and reporting legal infractions and injured wildlife

7. Clear understanding of Park policies for interacting with members of the public, the press, etc., and enough basic knowledge of the biology of each species to permit such interactions to be positive and informative.

\section{Acknowledgments}

Funding for this Protocol was provided by the U.S. Geological Survey, Patuxent Wildlife Research Center, under USGS Cooperative Agreement number 1434-00 HQRV1573, Research Work Order 104. Special thanks to David Allen, Ruth Boettcher, Walker Golder, Anne Hecht, David Rabon, and Pea Island National Wildlife Refuge biologists and managers for reviews of these protocols. Administrative review was also provided by the following NPS personnel: Sherri Fields and Steve Harrison, and by Dr. J.B. French, USGS Patuxent Wildlife Research Center. 


\section{Selected References}

Altman, J., 1974, Observational study of behavior sampling methods: Behaviour, v. 49, p. 227-267.

Anders, F.J., and Leatherman, S.P., 1987, Disturbance of beach sediment by off-road vehicles: Environmental Geology, v. 9, no. 3, p. 183-189.

Boarman, W.I., 2003, Managing a subsidized predator population: reducing common raven predation on desert tortoises: Environmental Management, v. 32, p. 205-217.

Burger, J., 1987, Physical and social determinants of nest-site selection in piping plover in New Jersey: The Condor, v. 89, no. 4, p. 811-818.

Burger, J., 1994, The effect of human disturbance on foraging behavior and habitat use in piping plover (Charadrius melodus): Estuaries and Coasts, v. 17, no. 3, p. 695-701.

Cairns, W.E., 1982, Biology and behavior of breeding piping plovers: The Wilson Bulletin v. 94, no. 4, p. 531-545.

Cohen, J., 2005, Factors limiting piping plover nesting pair density and reproductive output on Long Island, New York: Blacksburg, Virginia, Virginia Tech University, Ph.D. dissertation, 256 p.

Cooper, S., 1990, Notes on piping plovers nesting at Cape Hatteras National Seashore during 1987: Chat, v. 54, p. $1-6$.

Coutu, S., Fraser, J.D., McConnaughey, J., and Loegering, J.,1990, Piping plover distribution and reproductive success on Cape Hatteras National Seashore: Blacksburg, Virginia, Department of Fisheries and Wildlife Sciences, Virginia Tech University, 67 p.

Dolan, R., Godfrey, P.J., and Odum, W.E., 1973, Man's impact on the barrier islands of North Carolina: American Scientist, v. 61, p. 152-162.

Drake, K.R., Thompson, J.E., and Drake, K.L., 2001, Movement, habitat use, and survival of nonbreeding piping plovers: The Condor, v. 103, p. 259-267.

Elias, S.P., Conway, C.J., Hadden, S.W., Hatfield, J., and Melvin, S.M., 2002, Waterbird monitoring protocol for Cape Cod National Seashore and other coastal parks, refuges and protected areas: U.S. Geological Survey report to the National Park Service, $44 \mathrm{p}$.

Erwin, R.M., Nichols, J.D., Eyler, T.B., Stotts, D.B., and Truitt, B.R., 1998, Modeling colony-site dynamics: A case study of gull-billed terns (Sterna nilotica) in coastal Virginia: The Auk v. 115, p. 970-978.

Erwin, R.M., Conway, C.J., Hadden, S.W., Hatfield, J., and Melvin, S.M., 2002, Waterbird monitoring protocol for Cape Cod National Seashore and other coastal parks, refuges and protected areas, USGS report to the National Park Service, $44 \mathrm{pp}$.

Federal Register, 1985, Endangered and threatened wildlife and plants; determination of endangered and threatened status for the Piping Plover; final rule: Federal Register 66 (50) CFR, p. 50,726-50,734.

Federal Register, 2001, Endangered and threatened wildlife and plants; final determinations of critical habitat for wintering Piping Plovers; final rule: Federal Register 50(50) CFR, p. 36,037-36,086.

Flemming, S.P., Chiasson, R.D., Smith, P.C., Austin-Smith, P.J., and Bancroft, R.P., 1988, Piping plover status in Nova Scotia related to its reproductive and behavioral responses to human disturbance: Journal of Field Ornithology, v. 59, no. 4, p. 321-330.

Golder, W.W., 1985, Piping plovers nesting at Cape Hatteras, N.C.: Chat, v. 49, p. 69-70.

Golder, W.W., 1986, Piping plovers nesting at Cape Hatteras, N.C., in 1985: Chat, v. 50, p. 51-53. 
Goldin, M.R., 1993, Effects of human disturbance and off-road vehicles on piping plover reproductive success and behavior at Breezy Point, Gateway National Recreation Area, New York: Amherst, Massachusetts, University of Massachusetts, M.S. Thesis, 128 p.

Goldin, M.R., and Regosin, J.V., 1998, Chick behavior, habitat use, and reproductive success of piping plovers at Goosewing Beach, Rhode Island: Journal of Field Ornithology, v. 69, no. 2, p. 228-234.

Haig, S.M., 1992, Piping Plover, in Poole, A., Stettenheim, P., and Gill, F., eds., Birds of North America, No. 2: Philadelphia, Pennsylvania, American Ornithologists Union, 18 p.

Haig, S.M., and Oring, L.W., 1988, Distribution and dispersal in the piping plover: Auk, v. 105, p. 630-638.

Hoopes, E.M., 1993, Relationships between human recreation and piping plover foraging ecology and chick survival: Amherst, Massachusetts, University of Massachusetts, M.S. Thesis, 106 p.

Houghton, L.M., 2005, Piping plover population dynamics and effects of beach management practices on piping plovers at West Hampton Dunes and Westhampton Beach, New York: Blacksburg, Virginia, University Libraries, Virginia Polytechnic Institute and State University, accessed 2005 at http://scholar.lib.vt.edu/ theses/available/etd-08222005-172829.

Johnson, C.M., and Baldassarre, G.A., 1988, Aspects of the wintering ecology of piping plovers in coastal Alabama: Wilson Bulletin, v. 100, p. 214-233.

Johnson, M., and Oring, L.W., 2002, Are nest exclosures an effective tool in plover conservation?: Waterbirds, v. 25 , no. 2 , p. $184-190$.

Kuklinski, M.L., Houghton, L.M., and Fraser, J.D. 1996, Piping plover breeding ecology on Cape Hatteras National Seashore with special reference to the effect of temperature on productivity: Blacksburg, Virginia, Virginia Tech University, Department of Fisheries and Wildlife Sciences, 71 p.

Lande, R., 1988, Genetics and demography in biological conservation: Science, v. 241, no. 4872, p. $1,455-1,460$.

Leatherman, S.P., and Allen, J.R., eds., 1985, Geomorphic analysis, Fire Island Inlet to Montauk Point, Long Island, New York: Reformulation study submitted to the U.S. Army Corps of Engineers, New York District, $351 \mathrm{p}$.

Loegering, J.P., 1992, Piping plover breeding biology, foraging ecology and behavior on Assateague Island National Seashore, Maryland: Blacksburg, Virginia, Virginia Tech University, M.S. Thesis, 247 p.

Loegering, J.P, and Fraser, J.D., 1995, Factors affecting piping plover chick survival in different brood-rearing habitats: Journal of Wildlife Management, v. 59, no. 4, p. 646-655.

Loegering, J.P., Fraser, J.D., and Loegering, L.L., 1995, Ghost crabs prey on a piping plover chick: Wilson Bulletin, v. 107, no. 4, p. 768-769.

Lyons, M., 2001, 2000 Piping plover breeding activities, Cape Hatteras National Seashore: Buxton, North Carolina, National Park Service, unpublished annual report, $10 \mathrm{p}$. 
Lyons, M., 2002, 2001 Piping plover breeding activities, Cape Hatteras National Seashore: Buxton, North Carolina, National Park Service, unpublished annual report, $13 \mathrm{p}$.

Lyons, M., 2003, 2002 Piping plover breeding activities, Cape Hatteras National Seashore: Buxton, North Carolina, National Park Service, unpublished annual report, $15 \mathrm{p}$.

Lyons, M., 2004, 2003 Piping plover breeding activities, Cape Hatteras National Seashore: Buxton, North Carolina, National Park Service, unpublished annual report, 18 p.

Mayer, P.M., and Ryan, M.R. 1991, Electric fences reduce mammalian predation on piping plover nests and chicks: Wildlife Society Bulletin, v. 19, p. 59-63.

Melvin, S.M., Griffin, C.R., and Macivor, L.H., 1991, Recovery strategies for piping plovers in managed coastal landscapes: Coastal Management, v. 19, p. 21-34.

Melvin, S.M., Hecht, A., and Griffin, C.R., 1994, Piping plover mortalities caused by off-road vehicles on Atlantic coast beaches: Wildlife Society Bulletin, v. 22, no. 3, p. 409-414.

Melvin, S.M., Macivor, L.H., and Griffin, C.R., 1992, Predator exclosures: A technique to reduce predation of piping plover nests: Wildlife Society Bulletin, no. 20, p. 143-148.

Murphy, R.K., Michaud, I.M.G., Prescott, D.R.C., Ivan, J.S., Anderson, B.J., and French-Pombier, M.L., 2003a, Predation on adult piping plovers at predator exclosure cages: Waterbirds, v. 26, no. 2, p. 150-155.

Murphy, R.K., Greenwood, R.J., Ivan, J.S., and Smith, K.A., 2003b , Predator exclusion methods for managing endangered shorebirds: are two barriers better than one?: Waterbirds, v. 26, no. 2, p. 156-159.

Nicholls, J.L., and Baldassarre, G.A., 1990, Habitat selection and interspecific associations of piping plovers along the Atlantic and Gulf Coasts of the United States: Wilson Bulletin, v. 102, p. 581-590.

Patterson, M.E., Fraser, J.D., and Roggenbuck, J.W., 1991, Factors affecting piping plover productivity on Assateague Island: Journal of Wildlife Management, v. 55, no. 3, p. 525-531.

Sauer, J.R., Peterjohn, B., and Link, W., 1994, Observer differences in the North American Breeding Bird Survey: The Auk, v.111, no. 1, p. 50-62.

Staine, K.J., and Burger, J., 1994. Nocturnal foraging behavior of breeding piping plovers (Charadrius melo$d u s)$ in New Jersey: The Auk, v. 111, no. 3, p. 579-587.

Watts, B.D., and Bradshaw, D.S., 1995, Ghost crabs prey on Piping Plover eggs: Wilson Bulletin, v. 107, no. 4 , p. $767-768$.

Wilkinson, P.M., and Spinks, M., 1994, Winter distribution and habitat utilization of piping plovers in South Carolina: Chat, v. 58, p. 33-37.

Wolcott, D.L., and Wolcott, T.G., 1999, High mortality of piping plovers on beaches with abundant ghost crabs: Correlation not causation: Wilson Bulletin, v. 111, no. 3, p. 321-329.

Zonick, C.A., 2000, The winter ecology of piping plovers (Charadrius melodus) along the Texas Gulf Coast: Columbia, Missouri, University of Missouri, Ph.D. Dissertation, 169 p. 


\section{Appendix: Glossary of Terms}

Backshore $^{\text {a }}$ The upper part of the beach above the normal reach of the tides (high water), but affected by large waves occurring during a high.

Berm $^{\mathrm{a}}$ A nearly horizontal plateau on the backshore, formed by the deposition of beach material by wave action.

Dune $^{\mathrm{a}}$ Accumulations of windblown sand on the backshore, usually in the form of small hills or ridges.

Fledge For piping plovers chicks, achievement of independence from parents—often considered to be 35 days of age or when able to sustain flight for $15 \mathrm{~m}$.

Foraging Searching for, acquiring, and ingesting prey.

Foredune Small dune seaward of the primary dune system, often accumulating around clumps of wrack or vegetation.

Habitat $^{\mathrm{a}}$ The place where an organism lives.

Intertidal zone ${ }^{\text {a }}$ The zone between the high and low water marks.

MOSH Moist substrate habitat, excluding high-wave energy intertidal zone - particularly mud flats, sand flats, ephemeral pools, and shores of brackish ponds.

Mudflat ${ }^{\mathrm{a}}$ or sandflat A muddy or sandy low-lying strip of ground by the shore, or an island, usually submerged more or less completely by the rise of the tide.

Overwash $^{\mathrm{a}}$ (1) The part of the wave uprush that runs over the crest of a berm or structure and does not flow directly back to the ocean or bay; (2) the effect of waves overtopping a dune.

Preyed upon (or depredated) Killed or destroyed by a predator.

Reproductive rate For piping plovers, number of chicks fledged / number of breeding pairs.

Sparse Vegetation In piping plover habitat, any zone where vegetation is penetrable by adults and broods (typically $<90 \%$ cover).

Swash zone ${ }^{\mathrm{a}}$ The zone of wave action on the beach, which moves as water levels vary

Wrack (1) Lines of organic material (usually vegetation and algae) deposited on the edge of the swash zone; (2) lines or clumps of organic material, usually vegetation or algae, deposited in the backshore during spring or storm tides, and often partially buried by sand.

\footnotetext{
${ }^{a}$ Voigt, B. 1998, Glossary of coastal terms, National Oceanographic and Atmospheric Administration, http://www.csc.noaa.gov/text/ glossary.html\#glossary.
} 


\section{Chapter 2-Management, Monitoring, and Protection Protocols for American Oystercatchers at Cape Hatteras National Seashore, North Carolina}

By J. Michael Meyers

\section{Introduction}

The Outer Banks region of North Carolina supports approximately 90 breeding pairs of American oystercatchers (Simons and others, 2004), along $160 \mathrm{~km}$ of beach, of an estimated 327 pairs surveyed in the state (Cameron and Allen, 2004). Since the 1990s, this population has sustained declines in breeding pairs at Cape Hatteras National Seashore (CAHA), e.g., on Hatteras Island nesting pairs declined from 24 to 15 from 1999 to 2004 (Simons and others, 2004). Reproductive success for CAHA has been very low [less than $(<) 0.1$ fledged per breeding pair] and sporadic depending on years and locations; however, some signs of successful reproduction have been noted at Cape Lookout National Seashore (just south of Cape Hatteras) on North Core and Middle Core Banks in 2004 (Simons and others, 2004). On Cape Hatteras, overall trends indicate that American oystercatcher nesting attempts could decline to a scattered few per island per year $(<5)$ in less than a decade.

Threats to nesting oystercatchers on CAHA are numerous and inter-related, but more than $51 \%$ of nest losses are from undetermined causes, which does not allow managers to correct the problem (Simons and others, 2004). Major causes of known nest failures ( $<49 \%$ of nesting attempts) are mammalian predation $(60 \%)$, overwash (25\%), avian predation (5\%), abandonment (5\%, possibly another cause), and humans (3\%), vehicles $(<2 \%)$, and ghost crabs $(<2 \%)$ (Simons and others, 2004). Sabine (2005) found strong associations with significantly reduced oystercatcher reproductive success/high predation and high levels of human disturbances on Cumberland Island National Seashore. Others have found reduced foraging for European oystercatchers in areas disturbed by humans (Verhulst and others, 2001). In other counties similar relationships have been found (to quote Sabine, 2005): "Human activities reduced reproductive success and influenced geographical distribution of African Black oystercatchers (H. moquini) in South Africa (Jeffery, 1987; Leseberg and others, 2000). Human disturbance and use of coastal areas have been implicated as primary causes of the extinction of the Canarian Black oystercatcher (H. meadewaldoi) (Hockey, 1987)."

The USGS Patuxent Wildlife Research Center developed this protocol, based on the best available scientific information, to guide management, monitoring and research activity at CAHA that would result in the protection and recovery of each species. These protocols do not attempt to balance the need for protection of these species with other activities that occur at CAHA, nor was NPS management policy considered in detail. A draft of the protocols was sent to species experts for scientific review; the final draft of protocols were reviewed by NPS personnel to ensure that description of recent management at CAHA was accurately represented and that the approach was consistent with our work agreement.

\section{Species Description- Distribution and Biology}

\section{American Oystercatcher}

The American oystercatcher (Haematopus palliates) is easily identified by its large size (40-44 cm long, 400-700 g) and relatively long, bright reddishorange bill. Its bill and body colors make it very conspicuous for a shorebird. The upper, dark body feathers

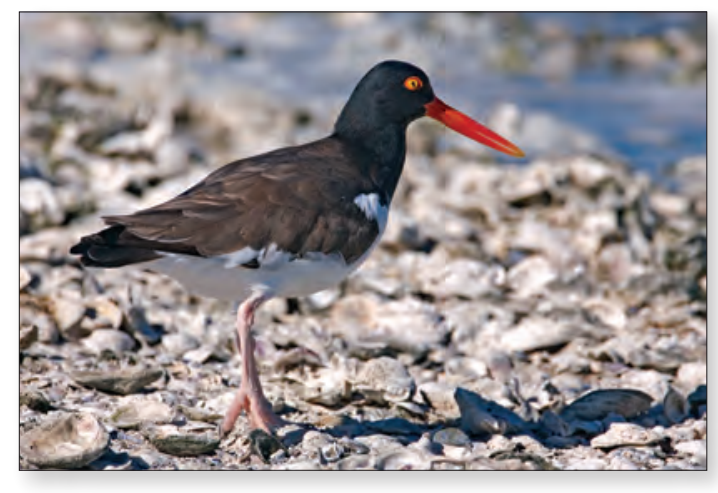

American oystercatcher (Haematopus palliates). Photograph by Alan D. Wilson. 
contrast with its bright yellow iris and white feathers on the flank and breast (Nol and Humphrey, 1994). Sexes are similar in appearance with females slightly larger than males.

Oystercatchers build nests near or on the beach by scraping many shallow depressions in the sand (4-6 $\mathrm{cm}$ deep and $20 \mathrm{~cm}$ in diameter) in close proximity, but choose only one scrape to build a nest. Oystercatchers also build nests on sand and shell flats, marsh islands, and dredge spoil islands (Nol and Humphrey, 1994; McGowan and others, 2005). The nest may contain shell fragments, dead plants, small stones, and other debris (Baicich and Harrison, 1997). In North Carolina, nests are rarely more than 21-32 m from water (Lauro and Burger, 1989; Nol and Humphrey, 1994) and are often on a mound, which serves as a lookout for the birds (Baicich and Harrison, 1997). Colonial waterbirds (e.g., Common Tern, Sterna hirundo; Least Tern, S. antillarum; and Black Skimmer, Rynchops niger) often nest in American oystercatcher territories after oystercatchers begin nesting. Primarily monogamous, American oystercatchers may mate for life although few long term records exist (Palmer, 1967; Nol and Humphrey, 1994).

Both sexes incubate 3-egg (rarely 2 and 4) clutches for 24-28 days. Incubation may begin after laying the second egg (Nol and Humphrey, 1994) or invariably after the last egg (Baicich and Harrison, 1997). Pairs will re-nest if the eggs or nestlings are lost early in the season, but clutch sizes are rarely more than two eggs. Precocial and downy nestlings remain in the nest for 1-2 days and then move with adults within the nesting territory or into adjacent feeding areas, which can be 50 to $200 \mathrm{~m}$ away, depending on the local landscape, e.g., birds may move off nesting territory to marsh area inland from beach to feed young. Both adults brood nestlings $<7$ days old. Nestlings will crouch motionless when alarmed, which makes them difficult to see. They fledge in about 35 days. Fledglings depend on adults almost entirely until 60 days old (Palmer, 1967; Nol and Humphrey, 1994). Recent color-banding studies in North Carolina indicate that oystercatchers may return to the general vicinity to nest in later years (T. Simons, USGS, oral commun.), which can only be corroborated with additional return color-banded bird data and studies in other states.

In September, oystercatchers in northeastern United States migrate south to Virginia and other winter ranges further south along the Atlantic and Gulf coasts. Many breeding oystercatchers in the southern states are non-migratory. During winter, northern and southern birds form large flocks with up to 869 birds seen in one flock in December in Virginia (Kain, 1987) and South Carolina (Post and Gauthreaux, 1989).

\section{Habitat Descriptions}

Breeding habitat. - Oystercatchers inhabit marine environments because of their special adaptation - a knife-like bill (laterally compressed) — for feeding on bivalve mollusks from saltwater. During breeding from March to August, pairs can be located along the Atlantic coast from Boston south to Indian River County, Florida. In late February and early March, pair formation and nesting begins in dunes near the beach wrack, but also occurs on dredge spoils and oyster bars in salt marshes in more human-disturbed beach areas. Beach nesting habitats are flat, nearly open sand areas with sparse to no vegetation. In North Carolina, oystercatchers rarely nest on marsh islands and commonly prefer nesting on high sandy sites (Lauro and Berger, 1989; Nol and Humphrey, 1994). Marsh islands may become more common nesting habitat because of disturbances on beaches, but more research is needed (McGowan and others, 2005).

Foraging habitat. - Oystercatcher foraging habitats vary from oyster and mussel reefs/shoals to intertidal sand/mud flats. Preferred foods found in these habitats are shellfish (bivalves and mollusks) and marine worms. In the southern habitats, from Virginia south, the major food items include oysters (Crassostrea virginica), soft-shell clams (Mya arenaria), razor clams (Ensis directus), stout razor clams (Tagelus plebeis), ribbed mussels (Geukensia demissa), mole crabs (Emerita talpoida), sandworms (Nereis pelagica), limpets (Aemaeu sp.), jellyfish (Colenterata), sea urchins (Strongylocentratus sp.), starfish (Asteria spp.), and crabs (Bent, 1929; Tomkins, 1954; Cadman, 1979; Johnsgard, 1981; Nol, 1989). Winter and summer foraging habitats are similar because of the non-migratory behavior of oystercatchers in North Carolina although migration is not well documented (Nol and Humphrey, 1994). Current and future color-banding studies of American oystercatchers should provide information on the migratory status of the species in CAHA.

Breeding pairs roost on the edge of intertidal feeding areas. Oystercatchers are more common in areas with few predators, especially areas without domestic dogs and cats (Nol and Humphrey, 1994). In North Carolina, winter and migratory roosting habitats should be similar to breeding and roosting habitats, i.e., 
predator-free islands (e.g., dredge spoil islands) and other isolated habitats near foraging habitat. We have inadequate information in North Carolina on preferred roosting habitat during winter and especially during migration. Limited observations indicate that winter birds roost in open ground without vegetation in areas near foraging habitat (Tomkins, 1954). This information is critical because peak wintering oystercatcher populations occur in Virginia, North Carolina, and South Carolina (Nol and Humphrey, 1994).

\section{Threats to Reproduction and Survival}

\section{Direct and Indirect Effects on Populations}

Historical status of the American oystercatcher during the 19th Century is not clear for eastern United States. It is possible that the species may have nested on the entire coast, north to Labrador. By 1900, the oystercatcher was considered rare or accidental north of Virginia and scarce south of the state. By the 1950s, American oystercatchers began re-nesting in northeastern United States. In 1984, 42 breeding pairs nested in Massachusetts and similar increases occurred in other states. Earlier declines may have been related to lack of protection, egg collecting, and market hunting, both threats that no longer exist today (Richards, 1888; Nol and Humphrey, 1994).

Oystercatcher breeding success in North Carolina has been extremely low-one egg in 32 hatches (Davis and others, 2001). Current and future threats to the American oystercatcher are human use, i.e., human disturbance within important breeding, wintering, and migratory habitat; increasing predators, especially associated with human use; and development of coastal areas (Bent, 1929; Tomkins, 1954; Nol and Humphrey, 1994). Predators include red fox (Vulpes vulpes), mink (Mustela vision), skunk (Mephitis mephitis), dogs, cats, rats (Rattus rattus, R. norvegicus), American Crow (Corvus brachyrynnchos), and gulls (Nol and Humphrey, 1994). More recently, video nest recordings have documented raccoon (Procyon lotor), bobcat (Lynx rufus), and ghost crab (Ocypode quadratus) predation of oystercatcher eggs and nestlings (Sabine and others, 2005). Oystercatchers may lay another clutch if predators depredate their nests early in the season (Nol and Humphrey, 1994). Storms and high tides also reduce nesting success; sea level rise of $0.3-0.6 \mathrm{~m}$ in the next 50 to 100 years will reduce nesting success of shorebirds because of human development on suitable habitat created further inland (Titus, 1990; Pilkey, 2003).

Protection of oystercatcher feeding habitats requires an overall healthy environment, free from pollution, especially in coastal waters. Nesting areas require exclusion of humans in varying levels as well as management of Off Road Vehicles (ORVs) on the beach and occasionally predator management. Eight oystercatcher chicks (some with radios) have been documented in the last two years as mortality caused by ORVs crushing them on the beach (Simons and others, 2004, and T. R. Simons, USGS, oral commun.). In the future, habitat of national seashores, wildlife refuges, and state-owned wildlife management areas and parks will become increasingly more important to maintaining the population of American oystercatchers in the eastern United States as private land is developed along Atlantic beaches.

Currently, there are few studies of the effects of humans and vehicles on the reproductive (nesting) success of American oystercatchers (McGowan, 2004; Sabine 2005) or colonial waterbirds. Studies of colonial nesting waterbirds indicate that set-back distances, in general, should be at least $180 \mathrm{~m}$ from nesting areas (Rogers and Smith, 1995). Other investigators found similar data (flushed at 142 and $130 \mathrm{~m}$ respectively with human approach) for Common Terns (Sterna hirundo) and Black Skimmers (Rynchops niger) in Virginia and North Carolina (Erwin, 1989). In general, more emphasis is needed on the effects of wildlife studies and viewing, recreational activities, and the intensity of these activities on behavior of nesting and foraging waterbirds (Burger and Gochfeld, 1998).

For nesting American oystercatchers on Cumberland Island National Seashore, Georgia, recent studies indicate that human disturbance free zones should be a minimum of $137 \mathrm{~m}$ from the nest (upper $95 \% \mathrm{C}$. I. of mean flush distance from nest) and preferably 180 to $200 \mathrm{~m}$ (Sabine, J.B., oral commun.). Eurasian oystercatchers (Haematopus ostralegus) spent more time away and at greater distances from their nests when disturbed by researchers within $150 \mathrm{~m}$ of their nest (Verboven and others, 2001). In experiments on Eurasian oystercatchers, investigators determined that human disturbance reduced incubation time as well as foraging time on nearby mudflats. When disturbed during chick rearing, these same oystercatchers delivered less food 
to their chicks, which presumably would reduce reproductive success (Verhulst and others, 2001). Although the number of papers published on this subject increased from the early 1970s to the late 1980s they have declined in recent times (Hill and others, 1997). More research is needed on disturbance of nesting American oystercatchers if we want to protect and manage the population at current or increased levels in the Eastern United States.

\section{Protection and Current Management at CAHA}

Management for colonial waterbirds at CAHA has focused on reducing threats to nesting oystercatchers. Beginning in 2004, the approach to protect all beach-nesting birds and sea turtles has been to create a $150-\mathrm{ft}$ transportation corridor for ORVs and pedestrian traffic from the high tide line landward. Vehicles may drive or park within the corridor. Pedestrians, but not pets, may cross the corridor boundary (inland), except where designated as specific natural resource closures. Park staff post and close traditional areas of nesting oystercatchers using signs and symbolic fencing, beginning in April, although March is the time for oystercatcher territorial establishment in North Carolina. Park staff post additional sites with solitary-nesting birds when territories are established (dates unknown). When young hatch, sections of the entire beach from the water line to the dunes are closed to prevent direct mortality of chicks. In addition to management of ORVs and beach recreationists, mammalian predator control is also an ongoing management tool. Control of foxes, feral cats, raccoons, opossums, and skunks has been applied at Bodie, Hatteras, and Ocracoke Islands.

In 2005, more restrictive measures were attempted in a number of areas of CAHA. At Green Island, with cooperation from the NCWRC, closure signs were posted early in the season around the perimeter to protect the island for colonial waterbirds and American oystercatchers. Oystercatchers nested on Green Island in 2005. At Hatteras Island, an area of about 3 acres (2 ha) was closed around ephemeral ponds at Cape Point where terns, Black Skimmers, and one oystercatcher nested. Along South Beach on Hatteras, the upper beach was closed for about $1.5 \mathrm{~km}$ to protect nesting American oystercatchers (3 nested), which could also indirectly benefit least terns. At Hatteras Spit, an experimental escort program with bird monitors was attempted, resulting in employing additional law enforcement personnel. This was enacted largely to protect Piping Plovers and oystercatchers nesting on the Spit. From 0700 to 1900 h, ORVs were allowed in the ORV corridor once per hour in convoys escorted by monitors. The area was closed during the night. At North Ocracoke, there was little sign of bird activity, therefore no additional closure was needed. At South Ocracoke, the $150-\mathrm{ft}$ vehicle corridor was narrowed in one area to protect an intertidal zone where Piping Plovers had been observed feeding. Three oystercatchers nested at South Ocracoke this year within an existing closure area. ORVs were permitted to drive past the protected area in the backshore, but were restricted from the shore of Pamlico Sound.

The effects of the current management are that vehicles and recreationists may still gain access to more than $90 \%$ of the open beach habitats. People management and public education is needed during the critical stages of territorial establishment, nesting, and rearing of chicks for oystercatchers, which is a sensitive period for the birds.

\section{Adaptive Resource Management Approach (ARM)}

\section{Framework for ARM}

\section{Research and Management Questions to be Addressed}

Monitoring of American oystercatcher reproductive success on CAHA should address the following questions:

A. What are the number of nesting attempts and breeding pairs annually and what are their locations?

B. What is the daily egg and nestling survival (Mayfield Method) for a representative sample of oystercatchers nests (at least 30 monitored nests, if available, in each management area)?

C. Is predation high ( $>50 \%$ of nests depredated) and what are the major predators? 
D. Is disturbance by pedestrians and ORVs causing loss of nests (destruction or abandonment) and nestlings?

E. Is high predation associated with highly disturbed areas? And are oystercatchers being forced to nest in areas too low $(<1 \mathrm{~m}$ asl), making nests susceptible to spring tide overwashes?

\section{ARM Experiments}

Adaptive Resource Management (ARM) is an efficient method for using monitoring information for testing hypotheses, modifying management procedures, and determining causality for natural resource problems (Walters, 1986). With the vast amount of oystercatcher data already collected (Simons and others, 2004), additional experimental designs and sampling will permit evaluations for associations of explanatory variables (ORVs, visitors, and predators) on the reproductive success and survival of oystercatchers at CAHA (personal communication, S. Schulte, NCSU). Experiments that reduce the amount of disturbance, e.g., random seasonal closure of sections of beach to pedestrians and ORVS or regulated use (driving only at low tide, monitored, or permitted), will provide information on effects of these relatively undisturbed areas on oystercatcher survival or reproductive success when compared to disturbed treatments (controls). Experiments should include monitoring of amount of disturbances by pedestrians and ORVs in addition to information on oystercatcher reproductive success and survival. This could be done by remote means for vehicles (counters) or by direct counting of pedestrian use and disturbance. A video monitoring system may be useful. Video of people could be controversial (persons may need to be told that video monitoring is occurring). Experimental areas should have replicated treatments (preferably 3 , for disturbed and undisturbed) and should contain at least 10 oystercatcher territories or nests, but 20 would be preferred. These experimental areas should be selected for treatment randomly (disturbed or undisturbed $=$ closed or regulated). If predator over abundance is suspected in the experimental areas, then predator removal should be undertaken before the disturbed and undisturbed experiments begin (see Research Needs for predator controls). Exclosures for nests (for predators and human disturbance) will not work well in protecting American oystercatchers because they would have to be very large (137-200 $\mathrm{m}$ away and surrounding the nests) to prevent disturbance to most nesting pairs and are not practical in the dynamic beach forefront and back area.

\section{Research Needs}

Long-term research needs for American oystercatcher include not only daily survival estimates of eggs and nestlings, but also survival estimates of sub-adults (prior to breeding) and adults. An expanding colormarking program to help determine oystercatcher survival should provide data necessary for constructing population models (see http://www4.ncsu.edu/unity/users/s/simons/www/AMOYworkinggroup_2004.htm for details and Simons and others 2004). This program will also provide information on management goals for nesting success for national seashores in North Carolina and elsewhere in the southeastern United States. An excellent baseline of American oystercatcher reproductive success data has be compiled by government and private agencies and North Carolina State University, which should continue to provide information for managers (see Simons and others, 2004). Research and monitoring of suspected high predation levels will require real-time video recording of nests, which should provide excellent information for predator management (see Sabine, 2005 and Sabine and others, 2005). This technique works well for monitoring nests until the nestlings leave the nest area. After that time, use of small radio transmitters on nestlings in two representative areas (disturbed and undisturbed - people and ORVs managed) may provide information on causes of chick mortality, especially prior to fledging (Simons and others, 2004). Data collected from video nest monitoring will provide definitive proof of suspected predator problems, which will allow specific management recommendations for reducing predators when necessary. Removal of all larger mammalian predators, e.g., foxes, raccoons, and cats, may be warranted based on data collected by video monitoring or reproductive success studies. Experiments could be setup to determine the success of predator removal (see colonial waterbird section for details), but usually are not needed if nesting failure is high from predation (50 to 100\%). In this case a substantial reduction in overabundant predators will most likely increase oystercatcher nesting success. After predators are controlled or eliminated, experiments on effects of disturbance from pedestrians, dogs, ORVs, and others will be more likely to produce results that managers can use effectively. 


\section{Management Recommendations}

Three management options for American oystercatchers and their habitat are presented from the most conservative (low adverse effects) to one that might be considered "take" under the migratory bird regulations. Management options for oystercatchers should be discussed in cooperation with the USFWS and North Carolina Wildlife Resources Commission.

\section{Option A: Highest Degree of Protection}

\section{Recommendations:}

1. Completely close all areas used by nesting and foraging American oystercatchers during the last 10 years to recreational activities from March 15 to August 15. This may increase reproductive success in combination with other management practices, e.g., elimination of overabundant mammalian predators. Close winter roosting areas to recreation during times to be determined from winter roosting surveys in the future.

2. Allow essential vehicles access to restricted areas within the guidelines for Essential Vehicles section of Appendix G of the Revised Recovery Plan for Piping Plover (USFWS, 1996, see colonial waterbird section). Speed limits should be $10 \mathrm{mph}$.

3. Continue to conduct surveys for reproductive success and mammalian predators. Trap as needed to reduce predation levels when $>50 \%$ of nests are loss to predators. Use USDA Wildlife Services or approved USDA trappers.

4. Erect signs $200 \mathrm{~m}$ from nests to warn personnel of the nesting pair and reduce disturbance in the area by other biologists, law enforcement, and managers. Move signs to boundaries of chick foraging areas after hatching so that the vast majority of foraging area is protected.

\section{Predicted effects:}

Only limited effects from recreational impacts on nesting and foraging oystercatchers should occur with little habitat impacts from limited use of essential vehicles. Reproductive success will be related to success management of overabundant predators and natural weather (storms) and tide conditions, which could eliminate nests occasionally. Nesting oystercatchers and productivity should gradually increase during four to five year periods.

\section{Option B: Moderate Protection}

\section{Recommendations:}

1. Close specific areas for nesting American oystercatcher's in coordination with closure of beaches for nesting colonial waterbirds and Piping Plovers (Charadrius melodus). Important nesting areas and ones that have been closed in the past for oystercatchers are Hatteras Island: Cape Point, South Beach, Hatteras Inlet; Bodie Island: Bodie Island flats; and Ocracoke Island: areas from ramp 59 to ramp 72 in addition to sites mentioned in Option B for colonial waterbirds. See figure 3.1 for locations in colonially nesting waterbird section (Chapter 3). Place signs $200 \mathrm{~m}$ from nesting birds to warn persons of the nesting areas. Signs should have some educational value as well as law enforcement information.

2. Allow pedestrians only in oystercatcher territories and limit walking corridors to $50 \mathrm{~m}$ from high tide line. Pets must be kept on a short lease in these areas. Discourage and warn pedestrians about walking above the beach wrack, which could cause destruction of eggs. Encourage pedestrians to quickly move through the area be placing warning signs, e.g., "migratory bird nesting area...," and directional signs, e.g., "do not stop in bird nesting areas, move quickly to reduce disturbance to nesting birds."

3. At the remaining corridors outside the ones mentioned above, follow procedures established for ORV corridors in the colonial waterbird section. 
4. Enact recommendations number 2 and 3 in Option A above.

\section{Predicted effects:}

Expected effects may be slightly reduced nesting success caused by minor disturbances by pedestrians. ORV Essential Use may have a limited effect on hatchling mortality although signs should provide the drivers enough warning to reduce mortality if they reduce speeds to $5 \mathrm{mph}$ in nesting zones. Predators may be attracted to the area by refuse left by pedestrians; however, predator control may reduce this potential negative effect. Potential effect from Essential Vehicle Use is expected to be similar Option A.

\section{Option C: Minimum Protection}

\section{Recommendations:}

1. Restrict all ORV, boat (recommend coordination with other agencies), and pedestrian recreation to a corridor within $50 \mathrm{~m}$ of the oceanside mean high time line from sunrise to sunset at all sites used in the last 10 years by nesting American oystercatchers. This should be in effect from March 15 to August 15 for nesting birds. The corridor should be reduced or closed during the hatchling stage (assuming the pair were successful) to reduce chick mortality from ORVs. It should remain closed until August 15 (Sabine, 2005) or until 60 days (independence from adults; Nol and Humphrey, 1994) after last hatching date if nests were monitored in the area. Areas should be closed from sunset to sunrise for all recreation activities.

2. At the focal sites mentioned in Option B, prohibit kites, balls, frisbees, fireworks, pets, and trash disposal. Vehicle speed limits should be $10 \mathrm{mph}$.

3. Enact recommendations number 2-4 in Option A above.

\section{Predicted effects:}

American oystercatchers may persist mainly as unsuccessful nesters (daily nesting survival of $<0.92$ ) for 5-10 years, but will eventually be extirpated from areas of high human use. Subsistence resources will provide foraging and other needs for the species, but low reproductive success will mean the population will only maintain itself with immigration from other areas (if surpluses are being produced in other nesting areas).

\section{Monitoring Protocols}

A. Nesting and breeding success - All beaches should be searched for oystercatcher activity beginning in late March at least twice per week. Observers should record the locations (GPS), number (pair or single), behavior, courtship (piping display, see Nol and Humphrey, 1994), and evidence of scrapes. Areas with oystercatcher activity should be checked 3 times per week in early April and if possible more often as nesting and laying season approaches in late April. Once a nest is located it should be marked in an unobtrusive manner (e.g., numbered wooden paint stirrer $10 \mathrm{~m}$ east of nest), given an identification number, and checked every 3 days or more if possible. When checked initially, we recommend that the following information be recorded for the nest description: nest number; distance to high tide line (m); GPS location (UTM in NAD83); habitat (see glossary); and description of scrape substrate (digital photograph at $10 \mathrm{~m}$ from nest may be helpful). Monitoring data collection should proceed the same day with recording the following: date and time of check, nest number, number of eggs (flushing adults 3 times per week); status of the nest (laying, incubating, lost, abandoned, hatching [eggs pipping], hatched); number of adults; presence of potential predator, human, or ORV tracks within $30 \mathrm{~m}$ of nest; evidence of potential predator trails within $10 \mathrm{~m}$ of the nest; and suspected causes; date and time of nest check of egg or nestling loss; and detailed description of area if nest is lost.

After nestlings leave their nest (1-2 days old), observers should record the location and habitat of adults and chicks at least twice a week. Habitat and GPS locations should be collected (use for mapping feeding areas) in addition to nest number, the number of nestlings, number of adults, brood age if known, behavior of nestlings and adults (see glossary), chick loss, cause of chick loss if carcass is found and mortality is apparent, and signs of potential predators or threats (e.g., deep vehicle tracks, which prevent chicks from accessing the beach). 
B. Migration and wintering habitat-Surveys for oystercatchers should be coordinated with the winter Piping Plover survey. Locations (GPS as above), activities, habitat, and numbers of oystercatchers should be recorded and entered into a GIS database, if available, for each year. This will allow eventual detection of important use areas for oystercatchers during migration and winter.

\section{Reporting Procedures}

During the breeding season from mid April to June, interns and technicians should provide weekly updates of nests to biologists and managers. Changes, if possible, can be made in management procedures (e.g., widening exclosure) for nests not part of an experimental study, which may produce higher reproductive success.

\section{Data Management}

All data (hard copy) should be copied weekly and stored in a different location than the original. Data should be entered into computer files and verified by another person. Computer files must be backed up daily and in their entirety at least every week. Backup disks must be stored at a different location and preferably on the mainland in an area well protected from storm damage, which could eliminate all files in the area. Annual data backups should be sent to the regional office for archiving. Access or equivalent data management software is preferred for large data files and it will also reduce errors during entry. Excel or equivalent software is useful for management of smaller data sets. Please see the colonial waterbird section for addition information on data collection, training, and data management.

\section{Acknowledgments}

We appreciate the comments and technical review of T. R. Simons of the North Carolina Cooperative Wildlife and Fisheries Research Unit (NCCWFRU) and A. L. Wilke of The Nature Conservancy. We also acknowledge the discussions and information from D. Allen (NCWRC), S. Cameron (NCWRC), S. Shulte (NCCWFRU), and D. Rabon (USFWS).

\section{Selected References}

Baicich, P.J., and Harrison, C.J.O., 1997, A guide to the nests, eggs, and nestlings of North American birds (2d ed.): San Diego, CA, Academic Press, 347 p.

Bent, A.C., 1929, Life histories of North American shore birds, Part 2. U.S.: Washington, D.C., National Museum Bulletin, Number 146, 412 p.

Brown, S., Schulte, S., Harrington, B., Winn, B., Bart, J., and Howe, M., 2005, Population size and winter distribution of eastern American oystercatchers: Journal of Wildlife Management, v. 69, no. 4, p. 1,538-1,545.

Cadman, M., 1979, Territorial behaviour in American Oystercatchers (Haematopus palliates): Wader Study Group Bulletin, v. 27, p. 40-41.

Carney, K.M., and Sydeman, W.J., 1999, A review of human disturbance effects on nesting colonial waterbirds: Waterbirds, v. 22, no. 1, p. 68-79.

Cameron, S., and Allen, D., 2004, American Oystercatcher breeding distribution and population estimate in North Carolina: Raleigh, North Carolina, North Carolina Wildlife Resources, 6 p. 
Davis, M.B., Simons, T.R., Groom, M.J., Weaver, J.L., and Cordes, J.R., 2001, The breeding status of the American Oystercatcher on the East Coast of North America and breeding success in North Carolina: Waterbirds, v. 24, p. 195-202.

Erwin, R.M., 1989, Responses to human intruders by birds nesting colonies: Experimental results and management guidelines: Colonial Waterbirds, v. 12, no. 1, p. 104-108.

Hill, D., Hockin, D., Price, D., Tucker, G., Morris, R., and Treweek, J., 1997, Bird disturbance: improving the quality and utility of disturbance research: Journal of Applied Ecology, v. 34, p. 275-288.

Johnsgard, P.A., 1981, The plovers, sandpipers and snipes of the world: Lincoln, Nebraska, University of Nebraska Press, 404 p.

Kain, T., 1987, Virginia's birdlife: an annotated checklist: Virginia Avifauna No. 3, Virginia Society of Ornithology, $330 \mathrm{p}$.

Lauro, B., and Burger, J., 1989, Nest-site selection of American Oystercatcher (Haematopus palliates) in salt marshes: Auk, v. 106, p.185-192.

McGowan, C.P., 2004, Factors affecting nesting success of American Oystercatchers (Haematopus palliates) in North Carolina: Raleigh, North Carolina, North Carolina State University, MS thesis, 77 p.

McGowan, C.P., Simons, T.R., Golder, W., and Cordes, J., 2005, A comparison of Amercian Oystercatcher reproductive success on barrier beach and river island habitats in coastal North Carolina: Waterbirds, v. 28, p. $150-155$.

Nol, E., 1989, Food supply and reproductive performance of the American Oystercatcher in Virginia: The Condor, v. 91, p. 429-435.

Nol, E., and Humphrey, R.C., 1994, American Oystercatcher (Haematopus palliates), in Pool, A., and Gill, F., eds., The birds of North America, Number 82, accessed January 5, 2010 at http://bna.birds.cornell.edu/bna/ species/082/articles/introduction.

Palmer, R.S., 1967, Family Haematopodidae, pages 147-150 in Stout, G.,ed., Shorebirds of North America: New York, Viking Press, 247 p.

Pilkey, O.H., 2003, A celebration of the world's barrier islands: New York, Columbia University Press, 309 p.

Post, W., and. Gauthreaux, S.A., 1989, Status and distribution of South Carolina birds: Charleston, South Carolina, Contributions from the Charleston Museum, v. 18, 83 p.

Richards, T.W., 1888, Notes on the nesting habits of the American Oystercatcher: Oologist, v. 7, p. 103-104.

Rogers, J.A., Jr., and Smith, H.T., 1995, Set-back distances to protect nesting bird colonies from human disturbance in Florida: Conservation Biology, v. 9, no. 1, p. 89-99.

Sabine, J.B., III, 2005, Effects of human activity and predation on breeding American Oystercatchers: Athens, Georgia, The University of Georgia, M.S. Thesis, 99 p.

Sabine, J.B., III, Meyers, J.M., and Schweitzer, S.H., 2005, A simple, inexpensive video camera setup for the study of avian nest activity: Journal of Field Ornithology, v. 76, no. 3, p. 293-297.

Simons, T.R., Schulte, S., Cordes, J., Lyons, Marcia, and Golder, W., 2004, American Oystercatcher (Haematopus paliatus) research and monitoring in North Carolina: Raleigh, North Carolina, North Carolina Cooperative Fish and Wildlife Research Unit Annual report, North Carolina State University, Department of Zoology, 27 p.

Titus, J.G., 1990, Greenhouse effect, sea level rise, and barrier islands: Case study of Long Beach Island, New Jersey: Coastal Management, v. 18, p. 65-90. 
Tomkins, I.R., 1954, Life history notes on the American oystercatcher: Oriole, no. 19, p. 37-45.

Verboven, N.B., Ens, J., and Dechesne, S., 2001, Effect of investigator disturbance on nest attendance and egg predation in Eurasian Oystercatchers: Auk, v. 118, p. 503-508.

Verhulst, S., Oosterbeek, K., and Ens, B.J., 2001, Experimental evidence for effects of human disturbance on foraging and parental care in oystercatchers: Biological Conservation, v. 101, p. 375-380.

Walters, C.J.,1986, Adaptive management of renewable resources: New York, MacMillan Press, 374 p. 


\title{
Chapter 3-Management, Monitoring, and Protection Protocols for Colonially Nesting Waterbirds at Cape Hatteras National Seashore, North Carolina
}

\author{
By R. Michael Erwin
}

\section{Introduction}

The Outer Banks region of North Carolina supports a large number of colonial waterbird species that depend upon its extensive sounds and the near-ocean waters for feeding, and relatively undisturbed islands (or portions thereof) for nesting (for example, see Parnell and Soots, 1979 for one of the pioneering atlas projects on waterbirds in North Carolina). Many species of waterbirds are in jeopardy in the State, however (Parnell and Committee, 1977). Reasons for this are many: predation increases by mammals, competition with, and predation by, large gulls, especially herring gulls, Larus argentatus, human development, beach stabilization, and recreational disturbances on the outer beaches (especially Cape Hatteras National Seashore [hereafter, CAHA] and villages north, as well as extreme southern North Carolina in the Wilmington region), and perhaps mortality on the wintering grounds (Parnell and Committee, 1977, 1995).

The colonially nesting species of most concern for CAHA include: gull-billed terns, Sterna nilotica, common terns, S. hirundo, least terns, S. antillarum, and black skimmers, Rynchops niger. Gull-billed terns are considered to be "Threatened" in North Carolina, while the other three are "Species of special concern" both to the North Carolina Wildlife Resources Commission (fide D. H. Allen, NCWRC) and to the National Park Service (S. Harrison, NPS, unpublished report). Numbers of most breeding birds within North Carolina have declined over the past 20-30 years for all of these species. During the period 1977 to 2004, gull-billed terns declined from approximately 268 to only 99 pairs, common terns from 2,760 to only 570 pairs, and black skimmers from 976 to 623 pairs; however, least terns increased from 1,925 to 2,408 pairs in the same period (NCWRC database, fide D. Allen).

At CAHA, recent nesting by these species has been rather limited relative to population levels from the 1970s (table 3-1).

The USGS Patuxent Wildlife Research Center developed this protocol, based on the best available scientific information, to guide management, monitoring and research activity at CAHA that would result in the protection and recovery of each species. These protocols do not attempt to balance the need for protection of these species with other activities that occur at CAHA, nor was NPS management policy considered in detail. A draft of the protocols was sent to species experts for scientific review; the final draft of protocols were reviewed by NPS personnel to ensure that description of recent management at CAHA was accurately represented and that the approach was consistent with our work agreement.

\section{Species Descriptions- Distribution and Biology}

\section{Gull-billed Tern}

The gull-billed tern is a medium-sized (33-38 cm long, ca. 160-200 g) widely distributed "seabird" that often occurs at large inland seas in Eurasia as well as along the sea coasts in the U.S., the Mediterranean, and northern Europe (Parnell and others, 1995). In the United States, it occurs as two subspecies, with the Atlantic Coast and

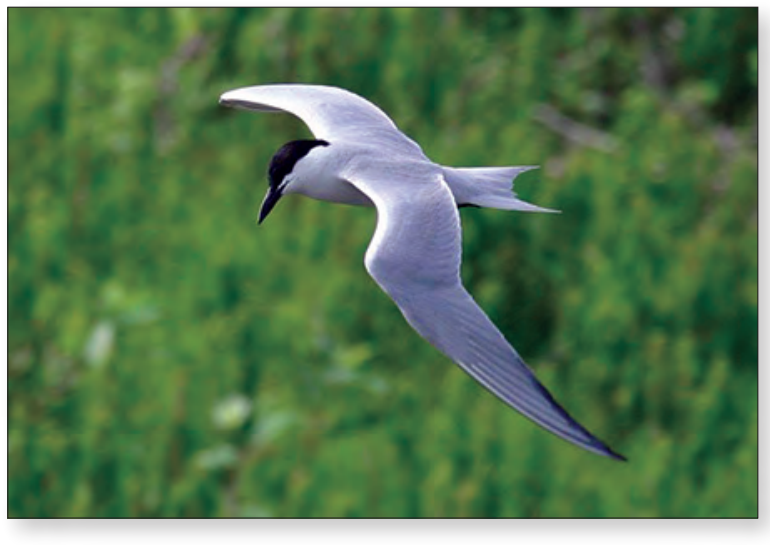

Gull-billed tern (Sterna nilotica). Photograph by G. Armistead. 
Gulf subspecies being designated Sterna nilotica aranea; the van rossemi subspecies appears to occur from the Salton Sea in California south to western Mexico (Parnell and others, 1995). On the Atlantic Coast, spring migration occurs from April to May primarily with birds arriving in North Carolina usually by mid April. The mating system is monogamous, and like many other seabirds, gull-bills have pair bonds that are probably long lasting. Nest-site establishment and egg laying occur usually in mid to late May in the middle Atlantic region, with incubation taking 22-23 days. Birds generally fledge at 26-30 days of age. The nests consist usually of a shell-lined scrape in the sand, or rarely, on wrack in marsh colonies. Nests contain from 2 to 3 brownish-blotched eggs (in the U.S., means around 2.2 eggs per nest; Parnell and others, 1995). The chicks are also cryptic in coloration, and are somewhat more precocial than the common tern, Sterna hirundo, or black skimmer, Rynchops niger, with which it coexists. Young may leave the immediate area of the nest within a few days, especially if disturbance levels are high. Pairs may renest if a nest is lost early in the breeding season. Both members of a pair incubate the eggs, with females taking the dominant role; both parents share brooding duties and both feed the young, even for an extended period after fledging occurs. One of the more unusual aspects of this species' biology is its diet; it depends more on terrestrial prey often than on aquatic organisms. It will prey upon insects, crustaceans, small mammals, and even young birds on occasion (Parnell and others, 1995).

After the breeding season in the mid-Atlantic region, fledged young and adults usually leave the colony sites by August, moving north for a short period before turning south for the fall and winter. Little is known of concentration areas during migration or winter, although wintering birds are known from Florida and the Gulf coastal region from west Florida all the way south to Honduras, and to Panama on the west coast (Parnell and others, 1995).

Table 3-1. Estimates of colonial waterbird nesting (in nesting pairs) at Cape Hatteras National Seashore from selected years, 1973 to 2003

[NPS, National Park Service; LT, least tern; CT, common tern; BS, black skimmer; GBT, gull-billed tern; PIPL, piping plover; pr, pairs; cols., collections]

\begin{tabular}{|c|c|c|c|c|c|}
\hline Location & 1973 & 1977 & 2001 & 2002 & 2003 \\
\hline $\begin{array}{l}\text { Bodie } \\
\text { Island }\end{array}$ & $\begin{array}{l}\text { None noted by } \\
\text { P.A. Buckley }\end{array}$ & 0 & 0 & 0 & LT-10 pr \\
\hline $\begin{array}{l}\text { Hatteras } \\
\text { Island }\end{array}$ & $\begin{array}{l}\text { LT-20 pr } \\
\text { CT-3-4 pr } \\
\text { BS-6 pr } \\
\text { "None at Cape Point even } \\
\text { in optimal habitat" } \\
\text { (P.A. Buckley) }\end{array}$ & $\begin{array}{l}\text { LT- } 88 \text { pr N } \\
\text { of Buxton } \\
(2 \text { cols. })\end{array}$ & $\begin{array}{l}\text { LT-53 pr } \\
\text { in } 5 \text { cols. } \\
(11 \text { in } 2000)\end{array}$ & $\begin{array}{l}\text { LT- } 5 \text { cols. } \\
\text { GBT- } 1 \text { col. } \\
\text { (no counts } \\
\text { made) }\end{array}$ & $\begin{array}{l}\text { LT-100 } \\
\text { CT-14 } \\
\text { BS-40 } \\
\text { (5 LT cols.) }\end{array}$ \\
\hline $\begin{array}{l}\text { Ocracoke } \\
\text { Island }\end{array}$ & $\begin{array}{l}\text { CT-100 pr } \\
\text { BS-65 pr } \\
\text { GBT-19 pr } \\
\text { LT-0 } \\
1 \text { PIPL nest probable } \\
\text { (P.A. Buckley)'; "Only } \\
\text { site for these species nesting } \\
\text { on main land barrier } \\
\text { beaches" (P.A. Buckley) }{ }^{1}\end{array}$ & $\begin{array}{l}\text { LT-33 } \\
\text { CT-802 } \\
\text { BS-286 } \\
\text { GBT-27 }\end{array}$ & $\begin{array}{l}\text { LT-210 } \\
\text { CT-387 } \\
\text { BS-193 } \\
\text { GBT-108 } \\
(2 \text { cols. })\end{array}$ & $\begin{array}{l}\text { "About same } \\
\text { as in } 2001 " \\
\text { (no counts } \\
\text { made) }\end{array}$ & $\begin{array}{l}\text { CT-172 } \\
\text { BS-225 } \\
\text { GBT-8 } \\
\text { LT-no firm } \\
\text { counts due to } \\
\text { many washouts }\end{array}$ \\
\hline
\end{tabular}

${ }^{1}$ References: For 1973, letter from NPS Chief Scientist, P.A. Buckley and F.G. Buckley to the Cape Hatteras National Park, (July 9, 1973); for 1977, Parnell and Soots (1979); for 2001-2003 date, source was Marcia Lyons, unpublished annual reports from the Cape Hatteras National Seashore. 


\section{Common Tern}

The common tern, as the name implies, is a common and widespread species across the temperate region of the northern hemisphere. A few disjunct populations occur in Bermuda and the southern Caribbean region as well (Nisbet, 2002). It is one of the medium-sized black-capped terns (31-35 cm long, 110-145 g body mass) that depends primarily on fish for prey (Nisbet, 2002). It is considered to be a focal species in the formation of mixed-species colonies of black skimmers, gull-billed terns, roseate terns, Sterna dougallii, and occasionally other species (Erwin, 1977). In North America, it is distributed primarily along the Atlantic Coast, but significant numbers also

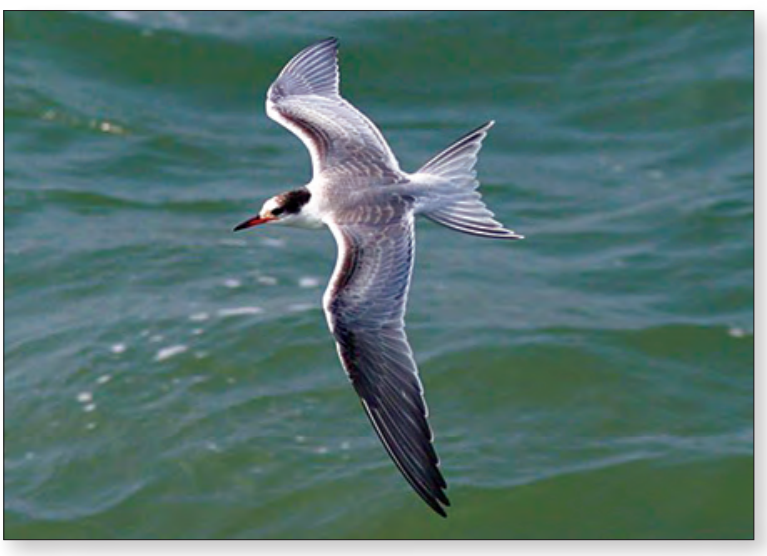

Common tern (Sterna hirundo). Photograph by B.L. Sullivan. nest along the St. Lawrence River and in most of the Great Lakes along the Canadian-U.S. border (Nisbet, 2002). Birds arrive in late April to early May along the mid Atlantic, and nesting begins from mid May to early June most years (Nisbet, 2002). The species is considered monogamous. Nesting habitats range from sandy-shelly beaches to salt marsh grasses and wrack to artificial sites such as navigation aides and duck blinds (Thompson and others, 1997). Clutch sizes vary but the modal size is three eggs, which are typically medium-dark brown mottled, and sometimes have a dark green background. The eggs are incubated for 22-23 days, with hatching occurring asynchronously, as in most other terns. Both sexes incubate, brood the young, and feed the brood. As in other terns, feeding of young occurs post-fledging, even until fall migration in some cases. Young remain near the nest (unless disturbed) for the entire prefledging period. Renesting may occur, sometimes into July, if early nests fail. Fledging ranges from about 25-30 days, depending on the order of hatching, condition, and other factors. The species seems to serve as a social locus for mixed-species colony formation, possibly because of their aggressive, protective nature (Erwin, 1979; Nisbet 2002). As indicated above, gull-billed terns and black skimmers often associate with common terns in the mid-Atlantic region. This species feeds by surface plunge-diving primarily on small $(<10 \mathrm{~cm})$ marine, brackish, or freshwater fishes (depending on the region) and invertebrates such as shrimp, or occasionally insects.

After breeding, common terns leave the colony sites in late July-August and often move north before staging at sandbars near inlets in September before heading south. Little information is known about winter range, but they are known from Florida south through the Caribbean to Peru and southern Brazil where tens of thousands have been recorded in late winter (see Nisbet, 2002).

\section{Least Tern}

The least tern, Sterna antillarum, is the smallest of the black-capped terns in North America. Five races are recognized in North America, although there are few differences genetically or morphologically among them (Thompson and others, 1997): S. a. antillarum occurs along the eastern coast of North America south through the West Indies, to Honduras and coastal Venezuela, S. a. athalassos (the Interior least tern) occupies the interior of the U.S. up the Mississippi River and its drainages, while $S$. $a$. browni is restricted to the California coast south to Baja California. In Mexico, two other subspecies are found, S. a. mexicana and $S$. a. staebleri along the western Mexico coast to Oaxaca, and east to Chiapas (Thompson and others, 1997). This

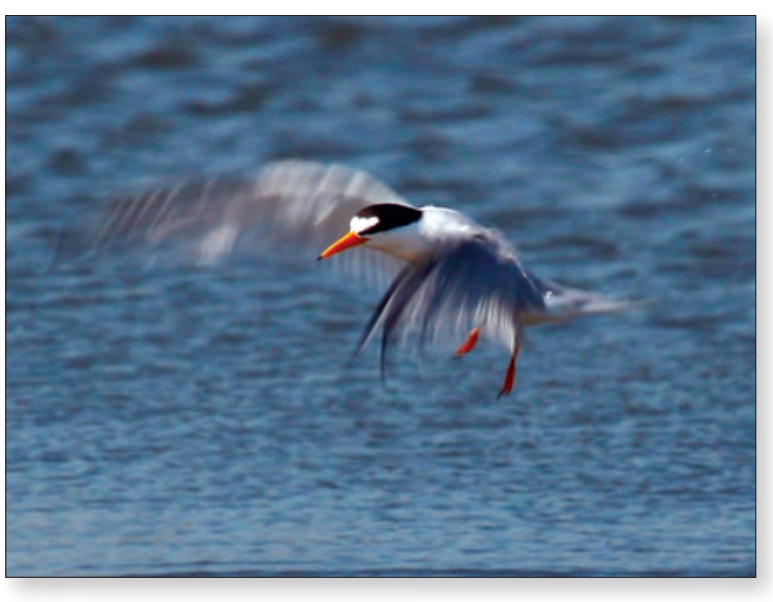

Least tern (Sterna antillarum). Photograph by Michael Ayers. 
diminutive tern weighs only about $44 \mathrm{~g}$ on average (Texas and Nebraska samples, Thompson and others, 1997) and is $21-23 \mathrm{~cm}$ in length. Spring arrival dates are from late March to mid April along the Carolinas. Unlike most other North American terns, it usually nests in single-species colonies, with nests often spread out.

Nesting habitats are usually open sandy-shelly beaches, with some colonies occupying rooftops in areas with heavy human disturbance on beaches (Thompson and others, 1997). Courtship lasts for 2-3 weeks in April and May, with egg laying from late May until June. Clutch sizes range from 1 to 3 eggs, with 2 the modal size in the mid-Atlantic. Eggs are highly cryptic, with the background color beige to light olive brown. Eggs are incubated by both sexes, but females do the majority. Incubation period is on average 21-22 days. When young hatch, they are quite precocial, moving from the nest area within a few days. They are able to achieve flight at about 20 days of age and some post-fledging parental feeding occurs for several weeks away from the colony site, as with other small terns. The species feeds on very small fish, shrimp, and a few other invertebrates in shallow waters close to the nest colony.

In late July-August, after breeding, least terns also move northward into the New York-New England region, before turning south to South America and the Caribbean, however data are very limited on winter ranges (Thompson and others, 1997). Like other terns, least terns tend to congregate at staging areas along the Gulf Coast in August and then seem to disappear in the winter (Thompson and others, 1997).

\section{Black Skimmer}

Rynchops niger, the black skimmer, is an unusual seabird in many respects. It is the only one of the Laridae to forage using its unusual "skimming" of the surface waters with its lower mandible, its adaptations for nocturnality (vertical pupil), and the large degree of sexual dimorphism. Morphologically, females average about $265 \mathrm{~g}$, while males average $35-40 \%$ larger at about $365 \mathrm{~g}$. Female length ranges from $40-50 \mathrm{~cm}$, while it is 50-60 for males (Gochfeld and Burger, 1994). All North American birds belong to the nominate subspecies, $R$. niger niger. There remains controversy about the systematics of races from South America (Gochfeld and Burger, 1994).

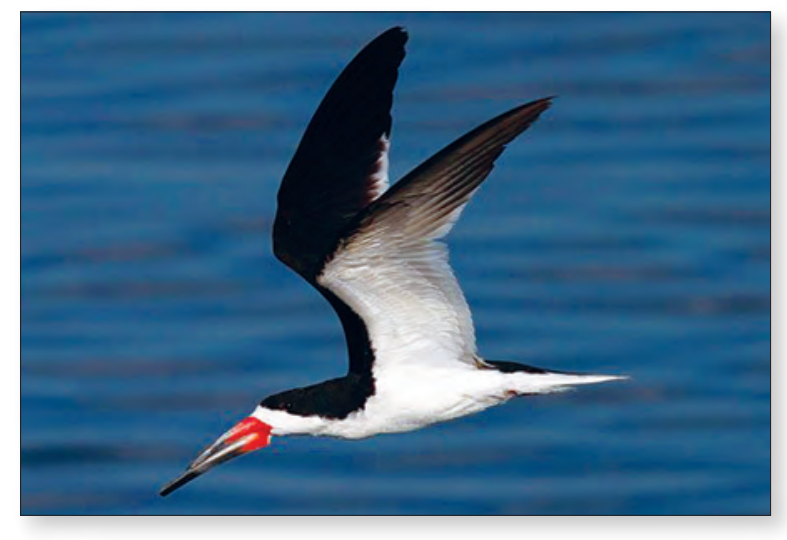

Black skimmer (Rynchops niger). Photograph by B.L. Sullivan.

Birds arrive in spring in the mid Atlantic region from late April to mid May, and nest building and egg laying occur usually from late May to mid June. Nesting colonies often form within vacant areas of common tern colonies, with common terns probably acting as a potential defense against predators (Erwin, 1977; Gochfeld and Burger, 1994). Nesting habitat consists usually of sandy-shelly areas on barrier islands, usually among common terns, or seldom in marshes on wrack or on shell bars (Gochfeld and Burger, 1994). Clutch sizes range from 2-4 eggs with a mean around 3.5 (Erwin, 1977) in the mid-Atlantic. Eggs are light buff with black blotches, and are laid (and hatch) asynchronously. Seldom do fourth-laid eggs result in fledged young. Both sexes incubate the eggs, brood and feed the young. Incubation period ranges from $22-25$ days. Young remain near the nest (unless disturbed) for most of the pre-fledging period of 28-30 days or more (Erwin, 1977). If nests fail early in the season, skimmers will renest perhaps several times. They are sometimes seen incubating eggs even as late as August in the mid Atlantic region (Burger and Gochfeld, 1990). As with terns, the fledged young are still fed by the parents often until the period they leave the colony site (Erwin, 1977). The prey of the black skimmer consists of a variety of small estuarine and marsh fishes and shrimp (Gochfeld and Burger, 1994).

In most years, by early August, adults and young leave the colonies and disperse northward from the Carolinas before heading south. Large flocks congregate at staging areas often with terns. Adults may remain with young during fall migration. Most birds from the Atlantic region winter from southern North Carolina to Florida south to the Caribbean and into Central and South America (Gochfeld and Burger, 1994). 


\section{Habitat Descriptions}

\section{Gull-billed tern}

Breeding habitat - Gull-billed terns are usually found nesting among other tern species on open, sandyshell beaches, either on large barrier islands or on islands created from dredged material (Parnell and others, 1995). Like piping plovers, they often occur on overwash fans that are shelly and mostly devoid of vegetation. They also occur on elevated shell ridges ("rakes") along the edges of marsh islands from Virginia to South Carolina (Erwin and others, 1998a,b), which they share with American oystercatchers (Haematopus palliates) and common terns.

Foraging habitat - Gull-billed terns are somewhat unusual among terns in not specializing on fishes. Instead, they are opportunistic, taking insects on the wing, feeding on a variety of invertebrates including fiddler crabs (Uca pugnax), decapods, marine worms, clams, as well as small marsh fishes (Erwin and others, 1998a,b). As a result of their opportunism, this species feeds over marshes, creeks, along the ocean and bay beach edges near its colony sites, as well as over agricultural fields sometimes several km from the nesting site.

Migration/winter roost habitat - On migration, little is known of roost habitat use, except that it generally is considered similar to those used during nesting, i.e., open beaches and sand spits along the coast (Parnell and others, 1995). Large staging concentrations have not been mentioned as for other species.

Breeding at $\boldsymbol{C A H A}$ - See table 3-1 for nesting history.

\section{Common Tern}

Breeding habitat - Common terns are one of the more widespread terns of the world, thus are considered generalists in many of their life history attributes, including nesting habitats. They nest mostly on open, sandyshell beaches on ocean coastal islands, as well as at inland island sites in freshwater lakes, or in Europe, in rivers (Nisbet, 2002). They are also known to nest in salt marshes along the coast, either on shell or on wrack, especially where human disturbance along the beaches is significant (Erwin, 1980). They seem to tolerate sparse vegetation at nesting sites more so than do their colony associates, black skimmers and gull-billed terns (Burger and Gochfeld, 1991). Nest substrates vary from sand and shell to wrack or salt marsh vegetation, and even some manmade structures such as old piers or channel markers (Burger and Gochfeld, 1991).

Foraging habitat - Common terns typically prey on small fishes and shrimp, often within several $\mathrm{km}$ of their breeding colonies (Nisbet, 2002). They feed in flocks in inlets and where tidal convergences occur along the coast, usually $<1 \mathrm{~km}$ from shore, but in inland freshwater areas, may be solitary feeders (Nisbet, 2002).

Migration/winter roost habitat - Common terns migrate through North Carolina in late August-October, with little information on habitat use. Most feeding continues to be close to shore, and staging areas are known at large sandy spits and bars at a number of North Atlantic sites with concentrations in thousands at some places (Nisbet, 2002). In winter, birds migrate to the Caribbean and South America where they seem to concentrate in large numbers in coastal lagoons in Brazil and Argentina (Nisbet, 2002).

Breeding at $\boldsymbol{C A H A}-$ See table 3-1.

\section{Least Tern}

Breeding habitat - Least terns are widespread in North America, and are more specialized in their nesting habitat than are common terns. Their nesting substrate is often the most bare sand-shell areas on coastal islands, or on riverine islands in the interior of the U.S. (Thompson and others, 1997). They are commonly also found nesting on dredged material islands and also on rooftops in a number of coastal areas, where pea gravel is used as part of the roofing material (Thompson and others, 1997). On coastal barrier islands, they often select colony sites either adjacent to inlets or in overwash areas, often interspersed among piping plover (Charadrius melodus) nests. Unlike the other Atlantic coastal tern species, least terns are usually found in 
monospecific colonies, often relatively small ( $<100$ pairs $)$ in size. Their nests are often widely spaced as well (Thompson and others, 1997). These adaptations are probably a response to ground predation.

Foraging habitat - In a manner similar to common terns, least terns feed on small surface fishes and shrimp from estuarine marshes, in lagoons, and along the ocean coast, usually within several $\mathrm{km}$ of the nesting colony (Thompson and others, 1997). Unlike common terns, they seldom are found feeding in large flocks over shoals of baitfish.

Migration/winter roost habitat - Least terns migrate from the mid Atlantic region, usually in August or September, with distinct migration flocks forming at certain sandy island sites along the route (Thompson and others, 1997). It is unclear whether they form mixed species flocks with other terns in migration. In late July or August, remote sandbars or sandy spits serve as roost sites. Species winters from Florida through the Caribbean, and into Central and South America (Thompson and others, 1997).

Breeding at CAHA-See table 3-1.

\section{Black Skimmer}

Breeding habitat - Skimmers prefer open, sandy habitats on barrier islands and dredged material islands along the coasts of the U.S. (Gochfeld and Burger, 1994). They may often be found in the shell-sand areas at the tips of barrier islands, or even on large shoals in inlets. They are almost always nesting in associate with other tern species along the Atlantic Coast (Erwin, 1977). With common terns, they are often found nesting in the open patches of the colony, with common tern nests more closely associated with vegetation (Erwin, 1977). On occasion, skimmers may also nest on wrack or on shell ridges in lagoonal salt marsh complexes along the Atlantic and Gulf Coasts, and even on rooftops along with least terns (see above) (Gochfeld and Burger, 1994).

Foraging habitat - Black skimmers usually feed very close to their nesting colonies (Erwin, 1977), and prefer quiet waters in salt marsh creeks, along lagoon edges, or along barrier islands in protected coves and inlets (Gochfeld and Burger, 1994). Like terns, they feed on small fishes of many species, small shrimp, and other small invertebrates that they capture by skimming the surface.

Migration/winter roost habitat - Migrate from the mid Atlantic region from September to November, with very large concentrations on sandy spits and sandbars in North Carolina in late fall some years (Gochfeld and Burger, 1994). Probably roost with terns at these isolated sites, but few data are available. Birds winter from Florida through the Caribbean and South America (Erwin, 1990; Gochfeld and Burger, 1994).

Breeding at CAHA-See table 3-1.

\section{Threats to Survival and Reproduction}

\section{Direct and Indirect Effects on Populations}

Weather and tides - During the breeding season, spring storms and high tides often cause flooding of nesting areas for all these ground-nesting seabirds (e.g., common terns, see Burger and Gochfeld, 1991; Nisbet, 2002). Further, sea-level rise threatens the long-range prospects for barrier island and marsh-nesting species (Reid and Trexler, 1992; Erwin and others, in press), and some models predict more frequent and severe storms in the future along the Atlantic Coast (Intergovernmental Panel on Climate Change, 2001).

Predation-Along many coastal beaches, direct effects by ground predators such as foxes (Vulpes vulpes), raccoons (Procyon lotor), rats (Rattus norvegicus) and feral cats (Felis domesticus) have increased in recent years as human populations have grown in coastal regions (Buckley and Buckley, 1976; Chabreck, 1988; Erwin and others, 2001). The result has been poor reproduction or major redistributions of species (Erwin and others, 2001). In addition, gulls are often predators on terns as well as competitors for nesting space (e.g., see Nisbet, 2002 and references therein for common terns); this includes great black-backed gulls (Larus marinus), herring gulls, and the smaller laughing gull (L. atricilla). In addition, in certain areas, other 
avian species may prey on terns and skimmers (or their eggs), such as peregrine falcons (Falco peregrinus), great horned owls (Bubo virginianus), fish crows (Corvus ossifragus) and others.

Human activities - As ground-nesting species, these colonial species are especially vulnerable to direct human activities such as off-road vehicles, aircraft disturbances, pedestrians - beachcombers, photographers, scientists, and even poachers (Buckley and Buckley, 1976; Erwin, 1980). Vandalism is rare in the United States, however, the unintentional mortality induced by off-road vehicles may be more common than realized as crushed young often go undetected (P.A. Buckley, oral commun.; R. Cook, oral commun.; B. Blodget, oral commun.). Indirect effects include such factors as sonic booms from nearby military operations, the presence of pets (both domestic and feral), leaving garbage as attractants (bringing in crows and gulls), and the spread of commensal predatory mammals such as raccoons and rats (see above). Even modest disturbances early in the spring when bird are first arriving and prospecting for breeding sites can be highly disruptive to colonial species (see Buckley and Buckley, 1976 for a detailed list of disturbances encountered in Atlantic coastal regions).

Environmental pollutants - A number of chemicals in the environment may be detrimental to the survival and/or reproduction of seabirds. Environmental contaminants are believed to cause reproductive failure in common terns, one of the more sensitive seabirds to organochlorine chemicals (Nisbet, 2002). Problem areas that have been researched in North America are mostly in the U.S. and Canadian Great Lakes region (Nisbet, 2002). No evidence of any population-wide wildlife effects of agricultural contaminants have been documented for the Outer Banks region.

Foraging habitat availability - Unlike foraging habitats of shorebirds, the habitats of feeding terns and black skimmers are not contiguous with their breeding areas. Least terns, common terns, and black skimmers usually feed from 1-10 km from their nesting colonies in shallow waters (Erwin, 1978; Burger and Gochfeld, 1990), while gull-billed terns feed on invertebrates primarily in marshes and over upland habitats (Parnell and others, 1995). Few data are available on trends in either forage fish populations in coastal waters, or on invertebrates to indicate whether there are current threats to foraging habitats. The effects of major hurricanes (e.g., Floyd in 1999) caused major declines in water conditions and marine life throughout Pamlico Sound in North Carolina for an extended period, as numerous contained animal waste facility dikes failed (Mallin, 2000).

\section{Protection and Current Management at CAHA}

Management for colonial waterbirds at CAHA has focused in the past on reducing the threats to nesting colonies. The general approach to protect all the beach-nesting birds and sea turtles has been to create a 150 - $\mathrm{ft}$ corridor for ORV and pedestrian traffic from the high tide line landward. Vehicles may drive or park within the corridor. Pedestrians, but not pets, may cross the corridor boundary lines, except where there are specific resource closure designations. Areas with nesting birds receive resource closures using signs. When young hatch, sections of the entire beach from the water line to the dunes are closed to prevent direct mortality of chicks. In addition to management of ORVs and beach recreationists, mammalian predator control is also an ongoing management tool. Control of foxes, feral cats, raccoons, opossums, and skunks has been applied at Bodie, Hatteras, and Ocracoke islands.

In 2005, more restrictive measures were attempted in a number of areas of CAHA. At Bodie Island, there was a narrowing of the corridor near the inlet, and much of the interior of the spit was closed including the cove area. Ponds near the inlet are important bird resource areas and were thus off limits. At Green Island, with cooperation from the NCWRC, closure signs were posted early in the season around the perimeter to protect the island for colonial waterbirds and American Oystercatchers. At Hatteras Island, an area of about 3 acres was closed around ephemeral ponds at Cape Point where terns and black skimmers nested. Along South Beach on Hatteras, the upper beach was closed for about $1.5 \mathrm{~km}$ to protect nesting American Oystercatchers, which could also indirectly benefit least terns. At Hatteras Spit, an experimental escort program with bird monitors was attempted, resulting in employing additional law enforcement personnel. This was enacted largely to protect piping plovers and oystercatchers nesting on the Spit. From 0700 to $1900 \mathrm{~h}$, ORVs were allowed in the ORV corridor once per hour in convoys escorted by monitors. The area was closed during the night. At North Ocracoke, there was little sign of bird activity, therefore no additional closure was needed. At South Ocracoke, the vehicle corridor was narrowed in one area to protect an intertidal zone where piping plovers had been observed feeding. ORVs were permitted to drive past the protected area in the backshore, but were restricted from the shore of Pamlico Sound. 
The effects of the current management are that vehicles and recreationists may still gain access to more than $90 \%$ of the open beach habitats. Little management is done during the critical stages of colony site prospecting and establishment, a sensitive period for colonial species as well as all bird species. Restrictions apply only when a colony is established. CAHA has a leash law for dogs but it is loosely enforced. There are no regulations regarding kite flying. With more than $100 \mathrm{~km}$ of beach to patrol, 24-hour access for recreation, no ORV permit system, and limited enforcement and resource management personnel, effective monitoring of important biological resources is strongly compromised.

\section{Adaptive Resource Management (ARM)}

It has long been recognized that many traditional wildlife monitoring programs involving simply counting animals or plants over time without a clear conceptual model can be wasteful of resources and devoid of linking cause and effect (see Walters, 1986; Wilson and others, 1996, as examples). Because ecological systems are very complex, there will generally be some level of imprecision or uncertainty as to causal effects, and some factors may change through time (Walters, 1986). Animal populations often differ from region to region in their responses to humans, predators, or other limiting factors (e.g., Erwin, 1980, therefore good monitoring programs of floral and fauna over large landscapes should always include three components: A research question(s) should be aimed at a desired goal, a management approach or experiment to try to determine causality, and a monitoring component established to determine the resultant magnitude, duration, and latency of changes associated with the management action or experiment. As monitoring results are revealed, a feedback loop allows the manager to either continue the current management practice or technique, or modify it until the desired trajectory is achieved.

\section{Framework for ARM}

\section{Questions to be Addressed}

A. What is the location and abundance of nests by species within CAHA? What is the hatching and fledg ing success of each species in each colony?

B. How does each tern-skimmer species use nesting habitat each year, and how site faithful is each species?

C. How consistent is roost habitat by species for migrants?

D. What factors limit nesting success?

E. What are the survival rates of young, post-fledglings, immatures (fledglings to first breeders), and adults? What are sources of mortality?

F. How significant is the CAHA population of each species to the State, mid Atlantic region, or Atlantic coast population?

\section{ARM-Some Examples}

A. Predator removal (Item 1. A and D above) - A common research question is: How does predator A affect the breeding success of Species B? In the context of Cape Hatteras, larger mammalian predators such as foxes, raccoons, and cats should be removed at all potential breeding areas (Ocracoke Spit, Hatteras Spit, Cape Point, Bodie Island Spit) as an ongoing management activity. Many examples exist at other national seashores and coastal refuges to demonstrate that meso-predator removal is essential for maintaining quality nesting habitat for colonial species without the need for further experimentation. Research questions that will require 
additional "fine-tuning" concern the most effective trapping mechanisms and timing for each species, however this is beyond the purview of these protocols.

At many national seashores and wildlife refuges, avian predators such as crows and gulls have been seen preying on eggs or young of a number of colonial waterbird species. In some cases, only a few individual predators may have learned to specialize on tern or skimmer colonies. Removal of selected individuals by shooting has proven to be effective at Chincoteague National Wildlife Refuge, Virginia (D. Stotts, USFWS, pers. comm.), S. B. McKinney NWR (Falkner Island), Connecticut (Dr. J. Spendelow, USGS, pers. comm..), and at Bird Island, Massachusetts (Dr. I.C.T. Nisbet, oral commun.). Where the problem may be more systemic, we commend field experimental approaches. It cannot simply be assumed that "all gulls are predators" as has been the case in some areas (P.A. Buckley, oral commun.). Research is needed to document the degree of the problem. An example of how one could go about testing the question of gull effects on nest success in the following way: First, setting up observation posts to observe the frequency and activity of gulls and other potential predators around the colony. If it appears that gulls are preying on nests, set up plots in tern colonies where 5-10 thirty-cm-high poultry wire exclosures containing 3-5 tern and/or skimmer nests could be randomly placed with a similar number of control plots. Placing monofilament line on poles spaced about 1.5-2 $\mathrm{m}$ apart and $2 \mathrm{~m}$ high deters gulls, but allows terns to fly into and out of the area (Blokpoel and Tessier, 1983; Quinn and others, 1996). Chi-square analyses of the number of hatched young could be conducted in each colony where there were sufficient numbers of nests. Following the fate of young would prove much more difficult, since the control (non-enclosed) chicks often move considerable distances from their nests. The results of the tests, including GPS locations of the exclosures, and individual nest results can be provided in the form of Excel spreadsheets to the NPS data manager within CAHA.

B. Effects of human disturbance (Item 1. D above) - In coastal areas, human recreation in the form of pedestrian and vehicular (ORV) traffic can be disruptive. A null hypothesis is that disturbance frequency (and intensity) has no effect on nesting success of Species X. Conducting experiments on one or both aspects in the coastal seashore environment may not be feasible, as the unit of observation is the colony, not the individual nest (usually the case for all colonial species). Observations of nests are seldom statistically independent. With least terns, however, colonies are often scattered in small subgroups, such that it may be possible to set up a design where 3-4 colonies are identified as Controls (with minimum number of perhaps 3 visits during the nesting period), and an equal number of Treatments, with perhaps 3-5 visits per week. Each "visit" in a Treatment could be a human approaching and walking through the nesting area. The parameters measured could simply be the number of nests hatching at least one young, or the number of young fledged (very difficult for least terns). As above, the results could be analyzed by either Chi Square or Fishers Exact Test analysis, and data provided in the form of Excel spreadsheets to the NPS data manager.

\section{Research Needs}

A. Research is still needed to determine how indices of nesting success (e.g., ratios of young-of-year, prior to fledging, to breeding adults estimated at peak incubation) compare with more precise (e.g., Mayfield method) analyses of nest success. What are the trade-offs of nest visitation frequency and survival? (see question 1 above).

B. How site faithful are nesting colonies of each species, and how specific are migrant terns and skimmers to using the same beach segment (see questions 2 and 3 above). These questions can be addressed simply by monitoring use of locations using GPS devices and applying modifications of Markov models (see Erwin and others, 1998b).

C. How do survival rates differ among young of the year, immatures, and adults? (see question5 above). This question goes well beyond the usual needs of NPS management, but is an essential piece of information for developing Population Viability Analyses. We recommend that, where resources allow, the NPS provide support to researchers to address this question at least for species that are identified as high-priority species by the NPS, State of North Carolina, or Partners in Flight program. 


\section{Management Recommendations}

Here we provide three management options for colonial waterbirds and their habitats presented in order from the most conservative (least probability of adverse effects) to those considered more liberal (increasing probabilities of "take"). Because of the dynamic nature of the CAHA beaches and inlets, the management may change by location and time, and new sites (bars, islands) may require additional management. Management actions undertaken by CAHA relative to colonial waterbirds should be proposed and discussed with both the USFWS and the NCWRC, and other expert consultants as appropriate.

\section{Option A: Highest Degree of Protection}

\section{Recommendations:}

1. Completely close all waterbird nesting, foraging (ponds, pools) and roosting habitat that has been used in the past decade to all recreational activities from 15 April to 30 September. This will allow protection to areas recently used by waterbirds as well as providing the potential for future expansion of populations that have declined in the region in recent years. Thus, the Bodie Island Spit, Green Island, Hatteras Island (Cape Point, South Beach, and Hatteras Inlet), and North and South Ocracoke Island should all be posted with area closure signs with the dates posted.

2. Essential vehicles (law enforcement, NPS personnel, approved researchers) should only enter restricted areas subject to the guidelines in the Essential Vehicles section of Appendix G of the Revised Recovery Plan for the piping plover (USFWS, 1996). Vehicles should not exceed $10 \mathrm{mph}$.

3. In the spring (15 April to late May) and fall migration (August to 30 September) periods, all vehicles and personnel (NPS, researchers) should try to avoid tips of spits and inlet areas where colonial species often stage, or court (spring migration).

4. Continue current management practices of trapping potential mammalian predators, to include foxes, raccoons, feral cats, skunks, and opossums, especially on Hatteras and Bodie islands. Trapping should be performed either by the USDA Wildlife Services or those with professional experience in wildlife trapping, approved by USDA and in accordance with Department of Interior animal care and use guidelines.

5. Erect signs around the perimeter of nesting colonies. Although the areas will be closed to land-based recreation, boaters may come ashore, especially at inlets, and cause disturbance unless colonies are clearly marked. See Option B.4 below for details on signage.

\section{Predicted effects:}

There should be very limited direct recreational impacts on nesting or roosting colonial waterbirds within the boundaries of CAHA, and little impact on their habitats under this management regime. Most likely affected species would be least terns, as they sometimes establish small colonies in unexpected sites not previously used. There remains a small probability of Essential Vehicle impact on nesting waterbirds due to nests being crushed or death to young non-flying chicks as they disperse from the nesting colony.

\section{Option B: Moderate Protection}

\section{Recommendations:}

1. Completely close all potential breeding, roosting, and foraging habitat to ORV traffic and boat landings, at all sites where any terns or black skimmers have nested in the past decade, from April 15 until September 30. Even if no colony is established early in the season, late-season nesting by least terns and skimmers is common, and renesting may occur as late as August in some years. This should include Bodie Island Spit, Green Island, Hatteras Island, including Cape Point, South Beach, and Hatteras Spit, and Ocracoke Island, including North Ocracoke (inlet area), and South Ocracoke (fig. 3-1). 
2. At the seven sites mentioned above, pedestrians should be allowed within a narrow walking corridor at the high tide line from sunrise to sunset. Recreation such as kite flying, frisbee and ball use, pets, and firework use should be prohibited. This corridor may have to be narrowed if it infringes upon a nesting colony (see distance guidelines below).

3. At the remaining beach habitat outside of the seven areas mentioned, the ORV corridor should allow at least $10 \mathrm{~m}$ of ocean beach from the toe of the primary dune seaward to remain vehicle-free during the April 15 to September 30 period. If a colony becomes established, the ORV access may need to be modified for a section of beach to allow buffer distances to be established as indicated below. Vehicle speed should be limited to $10 \mathrm{mph}$.

4. At each colony where nests are initiated (including nest scrapes), resource closure signs with string should be erected. For least terns, signs should be placed $100 \mathrm{~m}$ from the perimeter of the colony. For other species of terns and black skimmers, the buffer distance should be $200 \mathrm{~m}$ (Erwin, 1989). Should a colony become established along a beach outside of a focal site, ORV access to the beach zone should be closed after young begin hatching, with the length of the beach closure depending on the dimensions of the colony. Note that these distances are less than those recommended in a National Park Service report on colonial waterbird management (Buckley and Buckley, 1976); however, their recommendations were conservative estimates, not based on empirical field experiments (Erwin, 1989).

5. Enact recommendations number 2-5 above under Option A.

Predicted effects:

There may be disturbance of adults at nesting colonies or staging areas at the focal sites, but with less probability of mortality of adults or nests. The risks of mortality to nests and chicks is higher in areas outside of the focal sites, however it is not highly likely that terns or skimmers will colonize these other areas. With pedestrian use of the focal sites, potential predators may be attracted to nesting colonies, but this effect is expected to be stronger outside of the focal areas. Outside of focal areas, pets are more likely to harass or harm adults or their chicks. Chicks, especially least terns, are at risk of being crushed by pedestrians as they move closer to the water line. Potential negative effects of Essential Vehicle use (ORV use by NPS staff, monitoring personnel, trappers) are the same as in Option A.

\section{Option C: Minimum Protection}

\section{Recommendations:}

1. Restrict all ORV and pedestrian recreation to a corridor within $50 \mathrm{~m}$ (ca. $150 \mathrm{ft}$ ) of the oceanside meanhigh tide line from sunrise to sunset, at all sites where colonial waterbirds have been documented in the past decade. Restrict boaters from landing at inlets where nesting colonies are within $200 \mathrm{~m}$ of the inlet. This should be in effect from April 15 to September 30. Even if no colony is established early in the season, late-season nesting by least terns and skimmers is common, and renesting may occur as late as August in some years. This includes the seven sites referred to in Option B-1 above. The corridor should be narrowed (or eliminated at certain segments of beach) if the buffer distance from an active nesting colony intercepts the ORV corridor, or when young hatch from a colony. Once the zone is narrowed, it should not be widened again without consultation with colonial bird experts. Any area with nesting birds should be closed from sunset to sunrise to all recreation.

2. At the seven focal sites mentioned above, prohibit pets, kites, ball games and frisbee throwing, fireworks, and trash disposal. Vehicle speed should not exceed $10 \mathrm{mph}$.

\section{Enact recommendations number 3-5 under Option B above.}

\section{Predicted effects:}

Adult birds are placed at risk by pedestrians and recreational ORVs and boats at the focal sites and all other areas. Nests and/or chicks may be crushed. Enforcement requirements are higher under this option than under options A or B, thus increasing the probability of harm to nesting terns and skimmers. Activity of ORVs and pedestrians in focal areas early in the spring when colonial waterbirds are prospecting for nesting sites may be detrimental to the probability of population increases for terns or skimmers (Buckley and Buckley, 


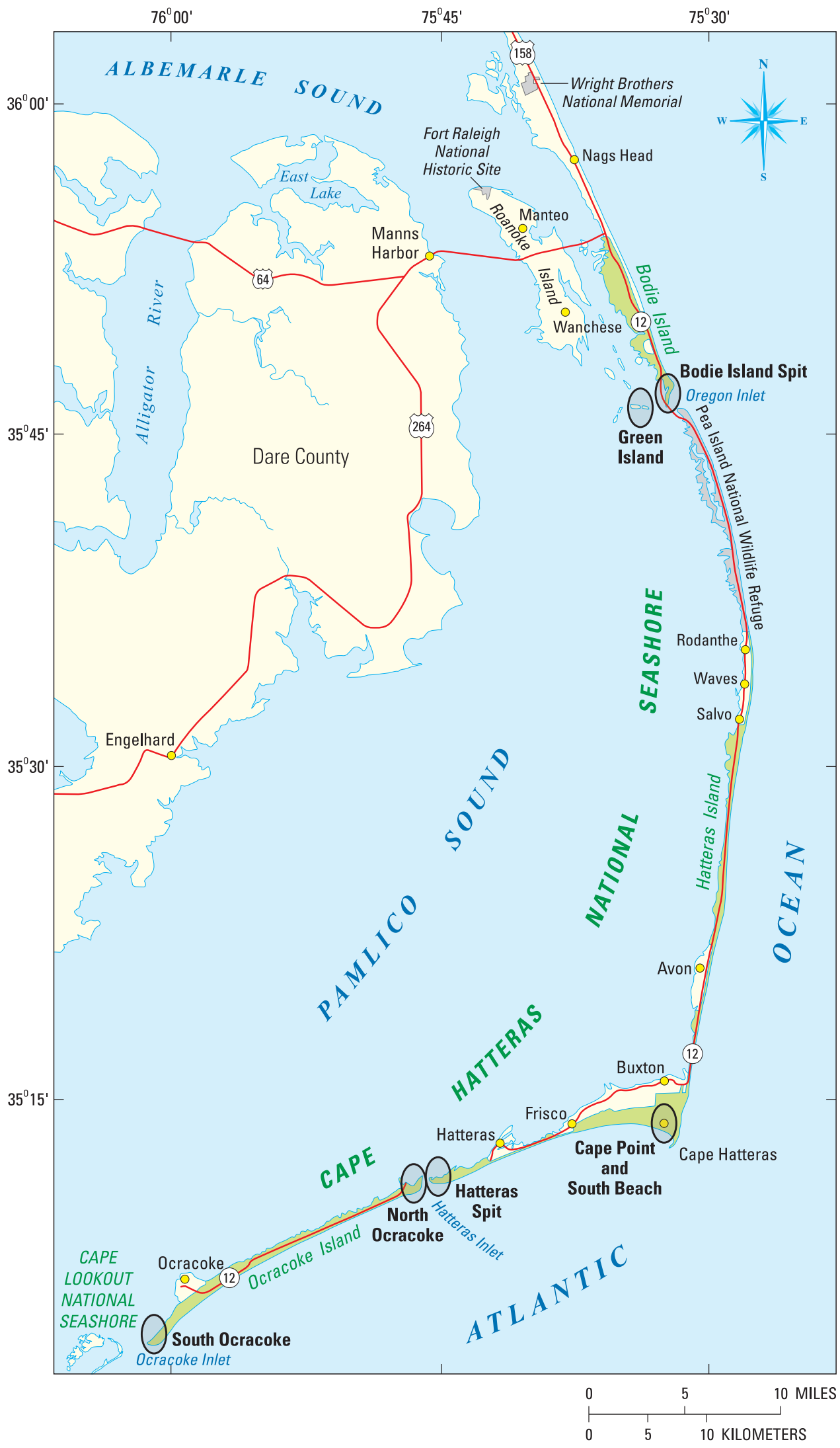

Figure 3-1. Cape Hatteras National Seashore, North Carolina. Ovals and labels indicate the seven major focal areas for colonial waterbird populations (modified from National Park Service map). 
1976). With more area open to recreation under this option, the potential for attracting gulls and crows is also enhanced. Effects outside of the seven focal areas and potential effects of Essential Vehicle use, and ORV monitoring are the same as under Options A and B.

\section{Monitoring Protocols}

A. Breeding populations and success (see 1A above): A fundamental question for managers concerns the location, abundance, and some assessment of reproductive success for species of management concern (see Erwin and others, 2003 for Cape Cod National Seashore). The latter issue can be very labor- and costintensive, however our recommendations aim to achieve a reasonable level of precision with normal staffing. If research funding is available, even more elaborate methods should be considered, including banding and radiotelemetry applications.

Least terns: Because least terns nest on open beaches similar to piping plovers, the locations and population sizes of this species can be surveyed intensively each year with little extra time commitment. All beaches are surveyed during the season either by ORV or on foot, covering all beaches where nesting is possible (see piping plover protocol). The center of each tern colony should be recorded using a GPS receiver. Assign each tern colony a local name (e.g. Cape Point) to assist relocating the site. Use the same name consistently over time (if possible, use the traditional one) to preclude errors when conducting population trends through time. Nesting begins as early as late May in some years and may extend into July. The number of incubating birds (= number of nests) should be recorded during 3 surveys in each colony during the period 5-20 June (the "A count" in Blodget and Melvin, 1996), then again after June 20 (the "B count") if a major change due to a storm occurs. Birds may renest until early July. Counts are best made by two independent observers. Keep these counts confidential so that individual observers can be "calibrated;" this helps in later comparing results when observers change (a common Park and Refuge situation). Observer changes can have major effects on population trend estimation (Sauer and others, 1994). A spotting scope or at least $8 \mathrm{X}$ binoculars should be used. A ground check is made to confirm the stage of egg laying (2-3 eggs is a full clutch). Entrance into the colony should be minimized especially during May and early June when birds are establishing nest sites and beginning egg laying. For most colonies, estimates can be made from vehicles at the periphery of the colony. On islands (e.g. Green Island), however, ground counts of nests should be made using the method outlined below for common terns, using mark-recapture methods. Avoid very warm days or rainy periods when flushing birds. Field data forms should be completed for each colony site visit. A standard colonial waterbird field data form has been developed by the NCWRC, and should be used to ensure standardization. Because least terns are notoriously unsynchronized in their nesting, numbers of nests should be estimated a minimum of three times (see above). If storms cause large-scale losses, renesting will occur; another survey should be made 2-3 weeks later. The best estimate of the number of nesting pairs in a colony is the maximum number of nests estimated among the three (or more) survey periods.

Estimating the breeding success, or annual fecundity, of species that nest on open beaches is somewhat easier than for species that nest in vegetation (see below). With least terns, eggs typically hatch after a 3-week incubation period; after this, observers should estimate the number of chicks at least three times in each colony. The first survey for chicks should be made 10-14 $\mathrm{d}$ after hatching begins, normally around the end of June. Second and third checks should be made in subsequent weeks (5-8 d apart). Nest surveys should be done using a spotting scope with $15 \mathrm{X}$ or more, if possible from a vehicle. The final check(s) should be conducted when the oldest chicks in the colony are 21-24 days (fledging about 24-27 d). On these late-stage surveys, observers should count from the vehicle the number of large chicks in attendance for the entire colony (while not precise, young-to-adult ratios provide an index of annual fecundity). This may require taking several counts from different vantage points. This estimate can then be compared with the estimated number of nesting adults determined at the peak of the nesting season to determine the index. (Note: elsewhere it has been suggested that the number of immatures should simply be compared with the number of attending adults; however this would result in an overestimate of nesting success, since unsuccessful nesters may have already left the colony area). Then an average can be calculated, and a "colony productivity estimate" can be derived. For example, if the ratio is 30 large fledglings to 30 nests counted earlier (i.e., 60 adults) that translates to 1 chick per nesting pair ( 2 adults $=1$ pair). If dead chicks are spotted, they should be examined for evidence of predation (e.g. missing head usually means owl predation). This information also is recorded on the colony 
data forms. To evaluate detection differences between observers, independent counts of adults and young should be conducted by the observers.

Without individually-marked young followed daily, precise estimates of survival will not be possible; instead the above method will only provide an index of annual fecundity. The value of the index can only be determined by conducting both types of studies simultaneously; this should be done at a sample of colonies every few years.

Common terns-gull-billed terns-black skimmers: For locations and population sizes of all colonies, observers should conduct ground counts using ORVs and on foot to estimate the number of nests. Green Island needs to be visited by boat in late May for nesting colonial species (and in early April for plovers and oystercatchers). As with least tern colonies, a GPS location should be taken in the center of each tern or skimmer colony. Timing of nesting is variable, depending upon year and species, therefore some annual adjustment of survey timing may be necessary. In general, for terns it is usually late May-early June in North Carolina. A nesting population estimate is conducted with a minimum of three observers using a mark-recapture method (Erwin and others, 2003). For small colonies ( $<500$ nests), the entire colony can be covered by the 3 (or more) observers. If colonies exceed ca. 1,000 pairs, a sample of $20-40 \%$ is recommended. After establishing a line along the long axis of the colony perimeter, a series of perpendicular transects is covered. The team walks in tandem through the colony during mid-to late incubation if possible (ca. early June for terns) counting and marking (dot of spray paint or water soluble marker on the nest edge) on 1-2 transects, or passes. Afterwards, they repeat the transects in reverse, with observers changing path positions, recording separately the number counted the second time that are marked versus unmarked (Lincoln-Petersen Index, see Smith, 1966). This allows one to estimate detection probabilities associated with the transect survey, i.e. the efficiency of the count (assuming a sample of at least 50 nests). After two transects of marking and recounting, the team can simply continue the count without further marking until the colony count is complete. Care should be taken however for the crew to stay abreast of each other to insure that they are not double counting nests as they walk. Observers should ensure that the entire colony area has been surveyed. At the completion of the survey, the total number of nests in the colony is estimated by converting the total count by applying the Lincoln correction as outlined as follows:

The equation in its simplest form is:

$$
N=(M * C) / R
$$

where

$N=$ the total estimate of the number of nests in the colony;

$M=$ the total number of nests observed and marked during the first pass through the survey area;

$C=$ the total number of nests observed on the second pass through the survey area; and

$R=$ the number of nests counted on the second pass that were already marked on the first pass.

As an example, if our Lincoln marking on two transects showed that we observed and marked 107 nests during the first survey $(M)$, then counted a total of 102 on the second pass $(C)$ of which 97 nests were already marked $(R)$, our $N$, the estimated total number of nests, is 113 . Thus, our first count of 107 was a $5.3 \%$ underestimate of the total. We then apply this $5.3 \%$ correction to the remaining counts for the colony for an overall corrected total estimate.

Precise estimates of reproductive success or annual fecundity for species such as common terns and black skimmers are difficult to obtain without a lot of effort and disturbance to the colony (Nisbet and Drury, 1972; Erwin and Smith, 1985). When young are large, they may run long distances from their nests upon disturbance; this exposes them to higher levels of predation (both intra- and interspecific). Therefore, observers should estimate annual fecundity using 4-6 randomly-located enclosed plots in different parts of the colony marked with wooden stakes ca. $60 \mathrm{~cm}$ long to demark corners of ca. $5 \times 5 \mathrm{~m}$ quadrats (if nest density is fewer than 7 nests per plot, the plot may have to be larger). Poultry wire fencing $(2.5-\mathrm{cm} \mathrm{mesh,}>40 \mathrm{~cm} \mathrm{high})$ should then be buried in the soil around the periphery of each plot. If possible, a sample of at least $10 \%$ of the colony is desired, with $20 \%$ being ideal, based on the estimated nest count made earlier. Each quadrat should be labeled and total number of nests should be counted in each plot during early (5-10) June. Plots should be set up within a few days after the nest count is done. 
After hatching begins (often the end of June), two visits are to be made. One is to be conducted about two weeks after hatching when numbers of chicks are counted in each quadrat. If the nests are visible from outside the colony, a scope should be used to count young from a distance to reduce disturbance. If vegetation is dense, observers will need to enter the quadrat to do the count. It is best for two people to do this. A second count should be made the same way about 8-10 days later (common terns fledge at about 24-26 d). The total number of young surviving in each quadrat divided by the number of nests in each will provide an estimate of "colony success." Variance among quadrats will be used to adjust the number of sample plots needed to accurately estimate the number of young fledged per colony in future years. After most of the young have fledged in the colony, at least one more late-season count should be made of the ratio of adults to young around the perimeter of the colony, preferably from a boat. This final count should be timed about $10 \mathrm{~d}$ after the last visit to count numbers of chicks.

As with least tern estimates, these estimates of annual fecundity will also not be as precise as if each nest were monitored, chicks marked, and followed every 1-3 days (see Eyler and others 1999). Instead, nest group (= plot), or "composite fecundity," estimates are obtained which represent an average number of fledglings per nest for the sample plot, or quadrat. This is still far superior to the frequent qualitative manner that is reported by Park and Refuge biologists (e.g. "poor", "average", or "good" success). As in other cases, the trade-off is accuracy versus time and colony disturbance.

If personnel limitations do not allow for establishing nesting enclosures as specified above, we suggest that at a minimum, a visit be made initially to determine when peak egg laying occurs, a second visit be made at about hatching time (3 weeks after egg laying), and at least two visits be made ca. 30-35 days after hatching to estimate the number of fledglings (the ratio of number of young: number of breeding pairs estimated, as above). To estimate this value, follow the procedure outlined above (3A) for least terns.

B. Migration and Wintering Populations and Habitat (see 1C above): Managers need to know which areas or habitats are key for migration staging of colonial waterbirds and shorebirds in spring and fall, and how consistently used are these sites (site fidelity). Because of the dynamics of barrier island habitats, the specific site (few hectare parcel) is less important than the larger landscape (e.g., the tip of an island). Because few terns and skimmers winter in North Carolina, the emphasis here is on staging areas during migration. Models to assess and quantify site fidelity can be adapted from those for colonial species (see Erwin and others 1998b).

Remote surveys: High tide roosts are seldom well documented for waterbirds. We tested aircraft methods for large-scale surveying of waterbirds on Cape Cod National Seashore in late summer-fall 2000 and winter 2001 and concluded that using small fixed-wing aircraft on a regular periodic basis was not logistically pragmatic there (Erwin and others, 2003). The regulations required of federal biologists for aircraft operations over federal lands, the difficulty in coordinating pilot and biologists' schedules, and inclement weather on the outer Cape all conspired to reduce our capability to survey when necessary.

In North Carolina, however, where small aircraft may be more efficiently utilized (or where federal law enforcement pilots commonly survey), we recommend use of either small helicopters (better sighting but very costly, fide P.A. Buckley) or small, high-wing aircraft to be flown at low altitude (300-500 ft). Low-level flying, i.e. below the $500 \mathrm{ft}$ ceiling, requires filing for a Special Use permit with the Office of Aircraft Safety (OAS) and biologists need to recognize that obtaining OAS approval of private aircraft and pilots is an elaborate and time-consuming process; not many vendors are amenable to such restrictions unless there are prospects for long-term contracting. We highly recommend using federal pilots within DOI whenever possible.

Once successfully contracted, the aircraft should fly the entire beach shorelines, bays and marshes, and adjacent open sandy uplands (sand bars near inlets) and important ( $>200$ birds) congregations should be visually located and recorded using GIS receivers. At least 5 surveys should be flown under stable weather conditions (low winds, no precipitation) during the spring migration period of 15 April to 30 May and fall migration, 1 August-30 September, for colonial bird and shorebird surveys. Copies of topographic maps of each bay or water body should be used to circle and identify by number the roost concentrations. A portable tape recorder should be used to record estimates of numbers for species or groups for each numbered location. Data are to be transferred to field forms as soon as possible afterwards. Where species identification is problematic, guilds can be used, such as "small terns" (for least, common, Forster's), or "small peeps" (for many of the small sandpipers such as least, semipalmated, western). One precaution should be noted however; for trend analysis, interpretation of the trends may be difficult using "group" data, e.g., "peeps", instead of individual species. Because of the special attention now being paid to certain shorebirds, such as red knots 
and whimbrels, care must be taken to estimate these species. As with any aerial survey or count, each observer should keep independent count records. These can then be "calibrated" by comparing photographic counts with ocular estimates, or by comparing the observer's accuracy to known numbers of objects using computer software programs (e.g., Wild Counts).

Five replicate aircraft surveys are considered a minimum for developing an index of consistency of site use. A major assumption here is that as species composition changes through the migration season, the preference for roosting habitat will not shift accordingly. This can be examined using the surveys conducted on the ground.

Ground Surveys: If aerial surveys cannot be used, ground surveys, combining boat, truck or ORV use will be required. We recommend that complete area surveys be performed at least twice to include all inlets, sand bars and spits, high open areas near feeding flats, and elevated areas on marsh islands be visited within the CAHA boundaries. These should be performed at or near high tide late in the day (within $3 \mathrm{~h}$ of sunset) to increase the probability that birds are attending roosts. Because of the longer time "window," we suggest that roost site surveys be performed during the fall shorebird migration period, from late July to late September.

At CAHA, the following areas should be included in roost surveys and should be surveyed 3-5 times: Bodie Island south spit, Green Island and north end of Pea Island, Hatteras Island, especially from Cape Point SW to Hatteras Spit, and all of Ocracoke Island. Survey area should include both beach and marsh (bayside) areas of the islands. Counts of birds and locations using GPS receivers should be recorded on field data forms and topographic maps. Natural landmarks will be used for boundaries. A map of each roost area (bay, river, beach area) is useful to accompany the field form, with each roost location numbered to correspond to the data form entry. Because location and approximate size of roosting flocks are most important, emphasis should be on site location and obtaining an overall estimate of numbers, rather than trying to obtain a precise species estimate. When sleeping, species are difficult to identity in many cases. Limiting observations at each site to only one brief survey period will often lead to underestimates of the numerical importance of sites; however more information is gained by visiting more sites over a larger landscape, even if sacrificing some accuracy at any given site.

\section{Reporting Procedures}

The data collected in the field have many potential uses and applications. For nesting location data, especially for the threatened piping plover, or endangered amaranth locations, GPS locational information needs to be conveyed as quickly as possible to Resource Management staff in order to implement protection measures. Similarly, witnessing violations of closure areas or other illegal activities needs to be conveyed to Law Enforcement staff as soon as possible. If violations of the Migratory Bird Treaty Act or Marine Mammal Protection Act (and sea turtle equivalent) are confirmed, notification needs to be made to the U.S. Fish and Wildlife Service-Raleigh Field Office, the National Marine Fisheries Service, and the North Carolina Wildlife Resources Commission as appropriate.

The field data should be collected in two forms: in field books as narrative accounts, and on field data forms developed in conjunction with other partner agencies, scientists and managers. The NCWRC maintains a database on colonial waterbirds and should be consulted on use of standardized data forms. Field forms should be quality checked by an independent reader, comparing field notebooks and forms where appropriate (see section below). When verified, the data should be electronically entered, analyzed where needed, summarized in reports in text, tabular and graphic form, and submitted to both CAHA management personnel and other cooperating agency personnel and other scientists and managers as requested. Reports should be available both in electronic form (pdf preferred) and in limited numbers of hard copy.

\section{Data Management}

A. Raw data collection: Field data sheets should include, at a minimum, the date, the reference location (GPS and usually a code number), a point or specific area, and observer name or initials. Because of the large amount of data included in these different data collection efforts, we strongly urge that all individuals engaged in data collection be trained in advance of the actual data collection period. Regardless of how clear a field form appears to be, questions always arise about how to record certain types of data. In addition, where counts 
of birds are recorded, we strongly urge that two observers keep independent records. Variation due to observer differences has been shown to be a major source of error (Sauer and others, 1994).

B. Data entry: Because the National Park Service (as well as other agencies) has determined that Microsoft Access will be the official database management software in the monitoring programs, we recommend it as the primary management tool. In some cases, Excel spreadsheets may be used since this is what the cooperators/contractors often provide. Again, consultation with the NCWRC is important here. Fortunately, the conversion of Excel tables to Access is not difficult and the structure of the tables is quite similar.

Because the Piping Plover is a Federally Threatened species, the USFWS and the North Carolina Wildlife Resources Commission have developed their own system of data collection and management, with the State taking responsibility for data coordination and management. The data reporting requirements are outlined in the Region 5 Piping Plover recovery plan (USFWS, 1996).

For the majority of the bird data sets, the data are entered directly from field forms into Microsoft Access, a relational database. One advantage of Access includes efficiency, because many fields of data (location, physical parameters) need not be reentered on each successive survey, and flexibility in presentation. Links can be made among tables of physical parameters, bird species estimates, feeding behaviors, etc.

C. Metadata: The metadata are best structured as separate components as the resource and scientific community needing different aspects of the data are quite different. We suggest developing metadata for the following databases within the CAHA database of natural resources: (1) piping plover database that contains breeding season, migration, and wintering data required by the USFWS Recovery Plan and State of North Carolina; (2) American oystercatcher database that includes breeding, migrating, and wintering data; (3) Colonial waterbird database that includes breeding season data on terns (especially common, least, and gullbilled) and black skimmer colonies; (4) Migrating (spring and fall) and wintering shorebirds and colonial species database, (5) a sea turtle database, including nesting and strandings, and (6) a beach amaranth database .

Quality assurance and quality control are best maintained by having the field data reviewed and entered into the database on the same day it is collected. Two individuals should first review the data to reduce error propagation. Generally it is best to have the person collecting the data also doing the data entry, followed by having a second person compare the computer printout with the original field sheets. This second step can be done at a later date to reduce fatigue on field days.

D. Data storage: Data from each of the six components should be given separate code names Field data sheets should be stored in a safe, low-fire-risk location in or near the NPS Headquarters in Manteo. Upon entry into a PC's electronic Access database, an extra copy of the database should be generated on a separate portable hard drive, or on CDs which then should be maintained in a separate building. If a computer network is available at the site, the files can be more easily transferred electronically to other PC sites, rather than having to physically transfer media between locations. Security demands by the NPS may require extra steps in the data management outlined here.

E. Data analysis techniques: The methods for analyzing the data will vary greatly depending upon the question and the level of analysis of interest. Excellent statistical support and advice is available both at the USGS Patuxent Wildlife Research Center (Drs. Jim Nichols, James Hines, John Sauer, William Kendall, Michael Runge, and Jeff Hatfield) and at NC State University (Dr. K. Pollock associated with the NC Cooperative Wildlife Research Center). Biologists at CAHA should consult with one or more statisticians whenever statistical analyses are to be conducted. Many population and metapopulation models are already available online, from Patuxent (see http://www.pwrc.usgs.gov), the USGS Colorado Cooperative Fish and Wildlife Research Unit (contact: K. Burnham), and elsewhere; however, these require some discussion with statisticians beforehand.

\section{Education and Outreach}

A. Public education: Although the strict protections detailed above are necessary to recover the colonial waterbird populations at CAHA, it is essential that the public be informed of management decisions and their justification as these protocols are implemented. Long-term sustainability of waterbird recovery at CAHA will depend on the cooperation of the public. Area closures and restrictions, and the reasons for each of them, need to be made clear. Continue posting all symbolic fence lines with signs that clearly indicate the species being 
protected. Interpretive signs with various species of waterbirds, including photos of nests and young, along with major points about their biology should help captivate the public interest and concern.

Provide visitors with informational brochures that contain information on terns and skimmers and the biological and legal reasons for their protection at CAHA. Indicate how closures will be used to better inform management in the future such that restrictions may possibly be eased. Interpretive walks in which visitors are guided to places to watch breeding and nonbreeding adults and broods through a spotting scope can also be a useful outreach mechanism, since untrained visitors will likely never otherwise see this species due to its cryptic coloration and inconspicuous behavior. Teaching the public to value birds as part of their beach experience is the most important management activity that CAHA can undertake.

Advertise bird protection efforts and management successes in local papers and magazines and write educational articles for these outlets. Submit public interest spots on beach wildlife on local radio stations. Ask that all articles that reporters write be checked by a manager or biologist so that corrections can be made if errors are found. Issue press releases detailing closures and other restrictions during both the breeding and nonbreeding seasons. Provide these press releases to local officials, the local press, local marinas, shops, special interest groups, etc.

B. Training: Provide training to all CAHA staff including sign crew, patrol, maintenance crews, etc. on behavior and monitoring techniques for both nesting and nonbreeding colonial waterbirds. This training should also include species identification, safe vehicle operations, and limiting activities in habitat.

Seasonal and permanent staff themselves need to have a subset of skills and knowledge before entering the field independently. These ideally include:

1. Ability to identify the adults, nests, and young of all protected species by sight, sound, and track evidence

2. Ability to identify breeding and nonbreeding behaviors by sight, sound, and other sign (e.g., nest scrapes, distraction displays)

3. Ability to observe adults, nests, and young of each species through optics and to record data without causing disturbance

4. Familiarity with the CAHA protocols for management and protection of each species

5. Basic knowledge of the laws protecting each species

6. Understanding of the process for dealing with and reporting legal infractions and injured wildlife

There should be clear understanding of Park policies for interacting with members of the public, the press, etc., and enough basic knowledge of the biology of each species to permit such interactions to be positive and informative.

\section{Acknowledgments}

We appreciate the comments and technical review of Dr. P.A. Buckley (retired, formerly NPS and USGS research biologist), D. Allen, NCWRC, S. Cameron, NCWRC, and D. Rabon, USFWS, Raleigh Field Office. Administrative review was also provided by the following NPS personnel: Sherri Fields and Steve Harrison, and by Dr. J.B. French, USGS Patuxent Wildlife Research Center. 


\section{Selected References}

Blodget, B.G., and Melvin, S.M., 1996, Massachusetts tern and piping plover handbook: A manual for stewards: Westborough, Massachusetts, Massachusetts Division of Fisheries and Wildlife, Natural Heritage and Endangered Species Program, $125 \mathrm{p}$.

Blokpoel, H., and Tessier, G., 1983, Monofilament lines exclude ring-billed gulls from traditional nesting areas, in Proceedings of the Ninth Bird Control Seminar, Jackson, B.W., and Dodd, B.J., eds.: Bowling Green Ohio, Bowling Green State University, p. 15-20.

Buckley, P.A., and Buckley, F.G., 1976, Guidelines for the protection and management of colonially nesting waterbirds: Boston, Massachusetts, National Park Service, 54 p.

Burger, J., and Gochfeld, M.G., 1990, The black skimmer: Social dynamics of a colonial species: New York, Columbia University Press, 355 p.

Burger, J., and Gochfeld, M.G., 1991, The common tern: its breeding biology and social behavior: New York, Columbia University Press, 408 p.

Erwin, R.M., 1977, Black skimmer breeding ecology and behavior: Auk, v. 94, p. 709-717.

Erwin, R.M., 1978, Coloniality in terns: the role of social feeding: The Condor, v. 80, p. 211-215.

Erwin, R.M., 1979, Species interactions in a mixed colony of common terns (Sterna hirundo) and black skimmers (Rynchops niger): Animal Behaviour, v. 27, p. 1,054-1,062.

Erwin, R.M., 1980, Breeding habitat use by colonially nesting waterbirds in two mid-Atlantic regions under different regimes of human disturbance: Biological Conservation, v. 18, p. 39-51.

Erwin, R.M., 1989, Responses to human intruders by birds nesting in colonies: experimental results and management guidelines: Colonial Waterbirds, v. 12, p. 104-108.

Erwin, R.M., 1990, Feeding activities of black skimmers in Guyana: Colonial Waterbirds, v. 13, p. 70-71.

Erwin, R.M., Conway, C.J., Hadden, S.W., Hatfield, J.S., and Melvin S.M., 2003, Waterbird monitoring protocol for Cape Cod National Seashore and other coastal parks, refuges and protected areas: U.S. Geological Survey report to the National Park Service, $79 \mathrm{p}$.

Erwin, R.M., Eyler, T.B., Hatfield, J.S., and McGary, S., 1998a, Diets of nestling gull-billed terns in coastal Virginia: Colonial Waterbirds, v. 21, p. 323-327.

Erwin, R.M., Nichols, J.D., Eyler, T.B., Stotts, D.B., and Truitt, B.R., 1998b, Modeling colony-site dynamics: A case study of gull-billed terns (Sterna nilotica) in coastal Virginia: Auk, v. 115, no. 4, p. 970-978.

Erwin, R.M., Sanders, G., Prosser, D., and Cahoon, D., in press, High tides and rising seas: potential effects on estuarine waterbirds: Studies in Avian Biology, v. 32, p. 214-228.

Erwin, R.M., and Smith, D.C., 1985, Habitat comparisons and productivity in nesting common terns on the mid-Atlantic coast: Colonial Waterbirds, v. 8, p. 155-165. 
Erwin, R.M., Truitt, B.R., and Jimenez, J.E., 2001, Ground-nesting waterbirds and mammalian carnivores in the Virginia barrier island region: Running out of options: Journal of Coastal Research, v. 17, no. 2, p. 292-296.

Eyler, T.B., Erwin, R.M., Stotts, D.B., and Hatfield, J.S., 1999, Aspects of hatching success and chick survival in gull-billed terns in coastal Virginia: Waterbirds, v. 22, no. 1, p. 54-59.

Gochfeld, M.G., and Burger, J., 1994, Black skimmer (Rynchops niger), in Poole, A., and Gill, F., eds., The birds of North America, No. 108: The Academy of Natural Sciences, Philadelphia, Pennsylvania, and American Ornithologists' Union, Washington, D.C., accessed December 10, 2009 at http://bna.birds.cornell. edu/bna/species/108/articles/introduction.

IPPC, 2001, Climate change 2001: Working Group II: Impacts, adaptation, and vulnerability: Intergovernmental Panel on Climate Change, Geneva, Switzerland, accessed December 10, 2009 at http://www.grida.no/publications/other/ipcc_tar/.

Mallin, M., 2000, Impacts of industrial animal production on rivers and estuaries. American Scientist, v. 88, p. 26-37.

Nisbet, I.C.T., 2002, Common tern (Sterna hirundo), in Poole, A., and Gill, F., eds., The birds of North America, No. 618: The Academy of Natural Sciences, Philadelphia, Pennsylvania, and American Ornithologists' Union, Washington, D.C., accessed December 10, 2009 at http://bna.birds.cornell.edu/bna/ species/618/articles/introduction.

Nisbet, I.C.T., and Drury, W.H., 1972, Measuring breeding success in common and roseate terns: BirdBanding, v. 43, p. 97-106.

Parnell, J.F., and Committee, 1977, Birds, in Cooper, J., Robinson, S., and Funderburg, J., eds., Endangered and threatened plants and animals of North Carolina: Raleigh, North Carolina, North Carolina State Museum of Natural History, p. 330-384.

Parnell, J.F., Erwin, R.M., and Molina, K.C., 1995, Gull-billed tern (Sterna nilotica), in Poole, A., and Gill, F., eds., The birds of North America, No. 140: The Academy of Natural Sciences, Philadelphia, Pennsylvania, and American Ornithologists' Union, Washington, D.C., accessed December 10, 2009 at http://bna.birds. cornell.edu/bna/species/140/articles/introduction.

Parnell, J.F., and Soots, R.F., Jr., 1979, Atlas of colonial waterbirds of North Carolina estuaries: Raleigh, North Carolina, UNC Sea Grant Publication, UNC-SG-78-10, 269 p.

Reid, W.V., and Trexler, M.C., 1992, Responding to potential impacts of climate change on U.S. coastal biodiversity: Coastal Management, v. 20, no. 2, p. 117-142.

Quinn, J.S., Morris, R.D., Blokpoel, H., Weseloh, D.V., and Ewins, P.J., 1996, Design and management of bird nesting habitat: tactics for conserving colonial waterbird biodiversity on artificial islands in Hamilton Harbour, Ontario: Canadian Journal of Fish and Aquatic Sciences, v. 53 (supplement 1), p. 45-57.

Sauer, J.R., Peterjohn, B., and Link, W., 1994, Observer differences in the North American breeding bird survey: Auk, v. 111, p. 50-62.

Smith, R.L., 1966, Ecology and field biology: New York, Harper and Row, 686 p.

Thompson, B.C., Jackson, J.A., Burger, J., Hill, L.A., Kirsch, E.M., and Atwood, J.L., 1997, Least tern (Sterna antillarum), in Poole, A., and Gill, F., eds., The birds of North America, No. 290: The Academy of Natural Sciences, Philadelphia, Pennsylvania, and American Ornithologists' Union, Washington, D.C., accessed December 10, 2009 at http://bna.birds.cornell.edu/bna/species/290/articles/introduction.

Walters, C.J., 1986, Adaptive management of renewable resources: New York, MacMillan Press, 374 p.

Wilson, D.E., Cole, F.R., Nichols, J.D., Rudran, R., and Foster, M., eds., 1996, Measuring and monitoring biological diversity: Standard methods for mammals: Washington, D.C., Smithsonian Institution Press, 409 p. 


\title{
Chapter 4-Management and Protection Protocols for Nesting Sea Turtles on Cape Hatteras National Seashore, North Carolina
}

\author{
By Jonathan B. Cohen
}

\section{Executive Summary}

1. The southeast U.S. population of the loggerhead turtle (Caretta caretta) has increased since the species was listed as federally threatened in 1978. Since standardized monitoring began in North Carolina in 1995, the number of nests at Cape Hatteras National Seashore (CAHA) fluctuated from year to year, and was lowest in 1996 and 1997 (39 nests) and highest in 2003 (101 nests). Green turtles (Chelonia mydas) and leatherback turtles (Dermochelys coriacea) have nested in small numbers at CAHA, sporadically over time.

2. Hatching success of sea turtle nests typically approaches $80 \%$. At CAHA hatching success from 19992003 was low when hurricanes hit during the nesting season (30\%-38\%), and ranged from $52 \%-70 \%$ otherwise. Hatching success at CAHA is usually correlated with hatching success in the surrounding subpopulation (north Florida to North Carolina).

3. Inclement weather, predation, and human recreation can negatively impact nesting rate and hatching success.

4. Currently there is little protection from recreation at CAHA for nesting females and nests that have not been found by monitors. We propose three management options to provide such protection, and to increase protection for known nests and hatchlings. We propose an adaptive management framework for assessing the effectiveness of these management options in improving sea turtle nesting rate and nest and hatchling survival.

5. We recommend continued efforts to trap and remove mammalian predators from all sea turtle habitat. We further recommend intensive monitoring and surveillance of protected areas to determine the extent and timing of threats to nests and broods, including nest overwash, predation, and disturbance or vandalism by humans.

6. Continue to relocate nests and assist stranded turtles according to North Carolina Wildlife Resources Commission guidelines.

7. Artificial light sources pose a serious threat to sea turtles in some parts of CAHA, which must be remedied immediately. We recommend that CAHA enact turtle-friendly lighting regulations and work with the communities within its borders to reduce light pollution and to eliminate artificial light sources that are directly visible from sea turtle nesting areas.

8. We recommend increased education and outreach to CAHA visitors, including requiring participation in an educational program before being granted nighttime beach access. The long-term success of sea turtle recovery will depend on public cooperation and positive public attitudes toward sea turtles and turtle management actions.

\section{Introduction}

The loggerhead turtle (Caretta caretta) is by far the most numerous sea turtle to nest at Cape Hatteras National Seashore (CAHA, fig. 4-1). Green turtles (Chelonia mydas) and leatherbacks (Dermochelys coriacea) have nested sporadically at CAHA (Altman and Lyons, 2003). CAHA is the northernmost nesting site for leatherbacks on the Atlantic Coast (Rabon and others, 2003). Loggerhead turtles were listed as federally threatened in the U.S. in 1978 (NMFS and USFWS, 1991a), and the other two species were listed as endangered in 1978 (NMFS and USFWS, 1991b) and 1970 (NMFS and USFWS, 1992), respectively. The U.S. 


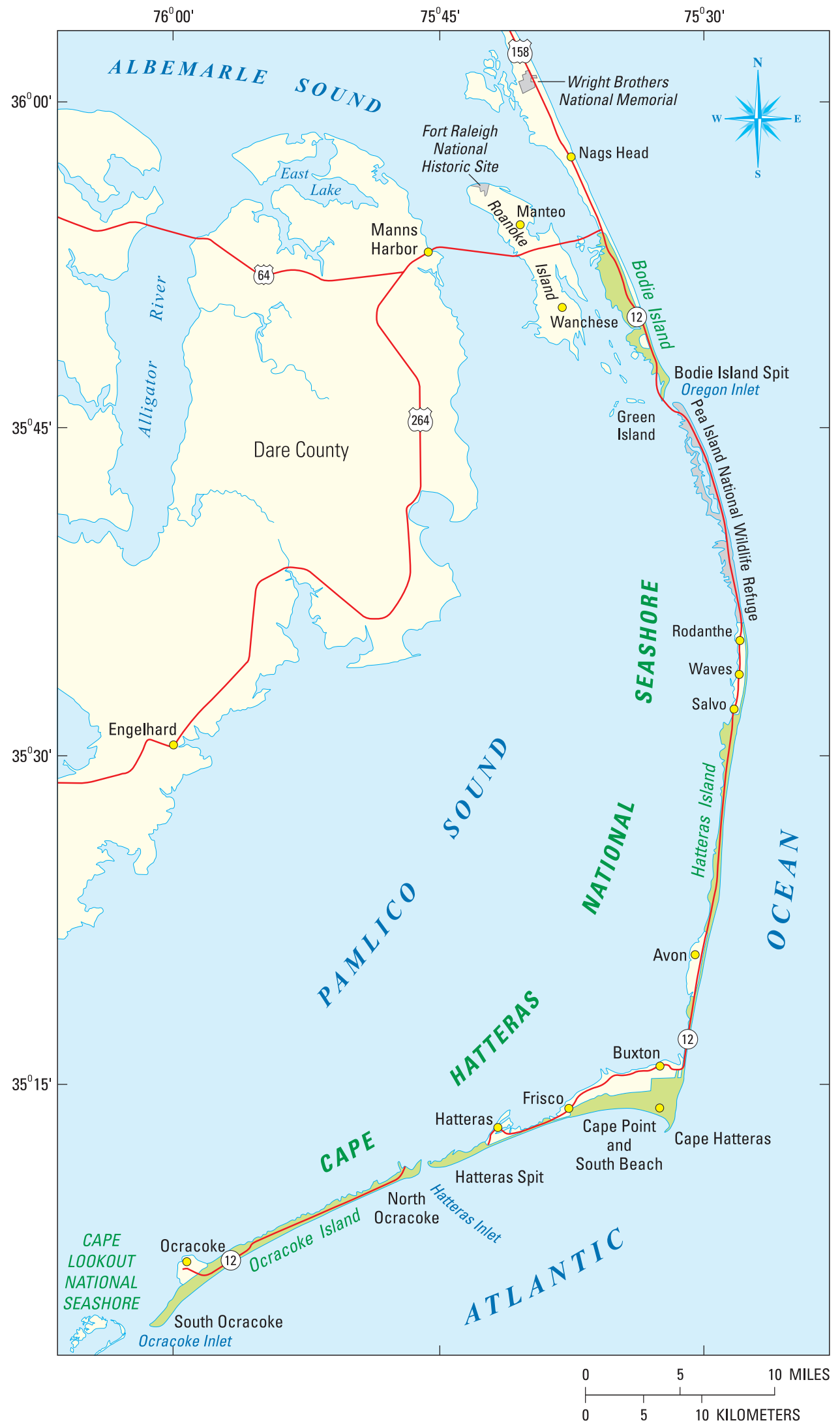

Figure 4-1. Cape Hatteras National Seashore, North Carolina (modified from National Park Service map). 
Atlantic loggerhead population has increased since listing, from approximately 14,150 animals in 1983 (NMFS and USFWS, 1991a) to between 32,000-56,000 by the year 2000 (Ehrhart and others, 2003). Within the northern subpopulation (north Florida to North Carolina), studies in South Carolina and Georgia have documented a decline in number of nests (Ehrhart and others, 2003). Based on genetic evidence, male loggerheads disperse freely among sites within the U.S. Atlantic population, while females are faithful to their natal sites (Bowen and others, 2005). Because sex ratio is determined by temperature during incubation (Miller and others, 2003), the northern part of the U.S. Atlantic population, which includes North Carolina, apparently provides a disproportionate number of males to the larger population (Mrosovsky and others, 1984; Hansen and others, 1998; Hawkes and others, 2005, written commun.).

One recovery goal for the loggerhead turtle in North Carolina is to attain the pre-listing nesting rate of 800 nests/season (NMFS and USFWS, 1991a). The number of nests in North Carolina fluctuated broadly around 800 nests/season from 1990-2003 (Godfrey and Cluse, 2003). Since standardized monitoring began in North Carolina in the mid-1990's, the number of sea turtle nests/season at CAHA was lowest in 1995 and 1996 and highest in 2002 (fig. 4-2). Only 49 nests were laid in 2004, but that year was poor for the entire southeast Atlantic Coast (M. Godfrey, North Carolina Wildlife Resources Commission, written commun.).

These protocols provide guidance for improving protection for sea turtle females and nests based on the results of current knowledge and adaptive management, in order to assist the Park in furthering its contribution to the recovery of sea turtle species while quantifying the effects of human recreation on sea turtles with more precision than has been done before. These protocols, as per the request of the National Park Service (NPS), are designed to provide as much protection for sea turtles (i.e., as little "take" as possible, as defined under the Endangered Species Act of 1973), without regard to budget, staffing, or impacts on other CAHA uses such as recreation. It will be up to the NPS to decide how best to incorporate these protocols into a more comprehensive management plan, given the logistical and political realities faced by CAHA.

The USGS Patuxent Wildlife Research Center developed this protocol, based on the best available scientific information, to guide management, monitoring and research activity at CAHA that would result in the protection and recovery of each species. These protocols do not attempt to balance the need for protection of these species with other activities that occur at CAHA, nor was NPS management policy considered in detail. A draft of the protocols was sent to species experts for scientific review; the final draft of protocols was reviewed by NPS personnel to ensure that description of recent management at CAHA was accurately represented and that the approach was consistent with our work agreement.

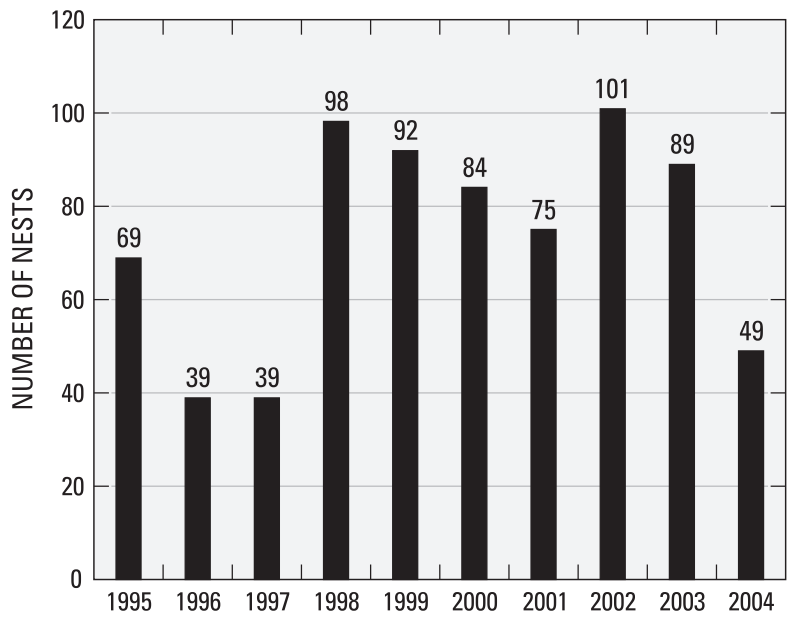

Figure 4-2. Number of sea turtle nests at Cape Hatteras National Seashore, North Carolina, 1995-2004. 


\section{Species Descriptions}

The loggerhead is the smallest of the turtles to use CAHA, with a mean carapace length of $92 \mathrm{~cm}$ and a mean mass of $133 \mathrm{~kg}$ (NMFS and USFWS, 1991a), compared to $102 \mathrm{~cm}$ and $136 \mathrm{~kg}$ in the green turtle (National Research Council, 1990) and $155 \mathrm{~cm}$ and 204-696 kg in the leatherback (NMFS and USFWS, 1992). Leatherbacks and green turtles breed primarily in the tropics and are rarer nesters at higher latitudes, while loggerheads have significant nesting populations outside the tropics (National Research Council, 1990). Approximately $95 \%$ of the sea turtle nests at CAHA are of the loggerhead

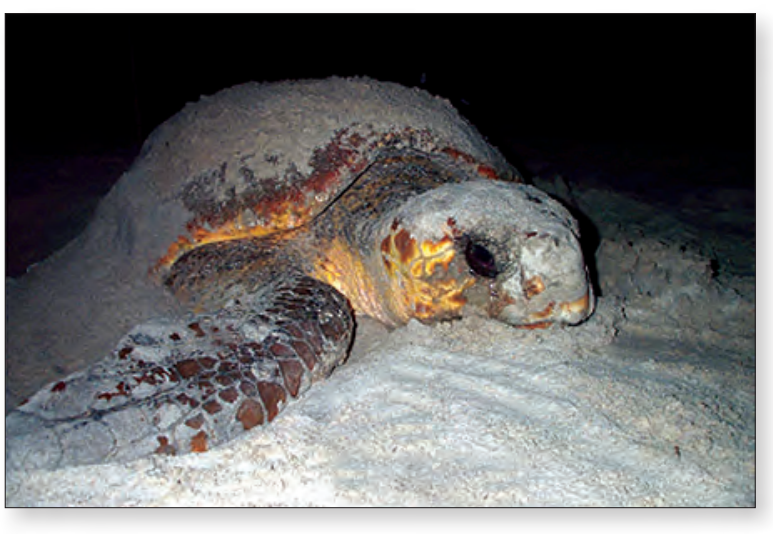

Loggerhead turtle (Caretta caretta). Photograph by Matthew Godfrey. (Altman and Lyons, 2003). For this reason we focus the remainder of the species account on loggerheads, with notes where the biology of the other two species differ in ways relevant to nesting site management.

Loggerhead females reach sexual maturity at 12-37 years (Witherington, 2003), with more recent research pointing to a minimum age of 30 years (Snover, 2002). At the start of the breeding season, they migrate from foraging areas on the continental shelf to mating grounds near their nesting beaches (Schroeder and others, 2003). Reproductive females exhibit natal philopatry (Miller and others 2003). Females may be inseminated by multiple males (Bollmer and others, 1999). After mating, males return to their foraging areas while the females emerge onto their nesting beaches. The following account of nesting biology is a synopsis of Miller and others (2003). Loggerhead females tend to nest on high wave energy, sandy ocean beaches. Gravid females emerge from the swash zone and crawl toward the dune line until they encounter a suitable nest site, typically on open sand at the seaward base of a dune, but sometimes in vegetation. The female clears away surface debris with the front flippers, creating a "body pit", then excavates a flask-shaped nest cavity with her hind flippers. Loggerheads lay an average of 112 eggs/nest. After laying, the female covers the nest with sand using all four flippers. Once the nest-covering phase is complete, she crawls back into the sea. Individual females may nest 1 to 6 times per nesting season, at intervals of 12-16 days, during the late spring to late summer. Intervals between nests shorter than 10 days indicate that the previous nest attempt was likely aborted due to disturbance. Mature loggerheads nest every 2 to 3 years, on average (Schroeder and others, 2003). Nest incubation period (from laying to hatching) depends on temperature, and ranges from 48 to 90 days at the extremes. Emergence of hatchlings from the nest cavity may take up to 2 weeks longer, but usually occurs within 4 days of hatch. Hatchling emergence from nests usually occurs at night when temperatures are lower and diurnal predators are inactive. Hatching success typically approaches $80 \%$, but survival to 1 year of age is $67 \%$ (National Research Council, 1990). Sex ratio of hatchlings depends on temperature during incubation. Below $29^{\circ} \mathrm{C}$, more males are produced than females, and above that temperature more females are produced (Carthy and others, 2003). Furthermore, fluctuating incubation temperatures often produce more females than stable temperatures, and temperature, hydration, and gas exchange during incubation can determine hatchling size, early swimming behavior, growth rate, and hatchling robustness (Carthy and others, 2003). Newly emerged hatchlings immediately head for the sea, most likely orienting toward the water by moving toward the brightest horizon and away from dark silhouettes (Lohmann and Lohmann, 2003). Sea turtles are most sensitive to blue and green light, and loggerheads in particular are averse to yellow light (Witherington and Martin, 1996). Once in the sea, hatchling loggerheads swim into the waves and eventually enter the open ocean, where they will spend the first 6.5 to 11.5 years of their lives primarily at the top of the water column, until finally moving to foraging areas on the continental shelf (Bolten, 2003). 


\section{Nesting Habitat}

Less is known about factors that cue nest site selection than about anthropogenic disturbances that discourage nesting (Miller and others, 2003). Typical nesting areas are "sandy, wide, open beaches backed by low dunes, with a flat, sandy approach from the sea" (Miller and others, 2003). Nesting is nonrandom along the shoreline, but studies of the physical characteristics associated with nests vs. random or non-nesting sites on the beach have produced varying results. Some factors that have been found to determine nest selection in certain studies are beach slope ( 3 of 3 studies), temperature ( 2 of 3 studies), distance to the ocean ( 1 of 3 studies), sand type ( 2 of 2 studies), and moisture ( 1 of 3 studies), although the results were occasionally contradictory (Miller and others, 2003). Other factors examined but not found to be significant were compaction, erosion, $\mathrm{pH}$, and salinity. Although the process of nest site selection is not well understood, a successful nest must be laid in a low salinity, high humidity, well-ventilated substrate that is not prone to flooding or burying due to tides and storms, and where temperature is optimal for development (Miller and others, 2003).

\section{Threats to Survival and Reproduction}

Threats to the loggerhead on the nesting grounds, as outlined in their recovery plan (NMFS and USFWS, 1991a), are representative of those faced by green and leatherback turtles.

\section{Weather and Tides}

Direct effects. - Storm events may destroy nests due to flooding or piling of eroded sand on the nest site.

Indirect effects.-Beach erosion due to wave action may decrease the availability of suitable nesting habitat (Steinetz and others 1998), which leads to a decline in nesting rate.

\section{Predation}

Direct effects. - Predation by mammals, birds, and ghost crabs may eliminate $100 \%$ of productivity on beaches where it is not managed (National Research Council, 1990). Fire ants may also kill hatchlings about to emerge from the nest cavity.

\section{Human Activities}

Direct Effects. - Crowding of nesting beaches by pedestrians can disturb nesting females and prevent laying (NMFS and USFWS, 1991). Furthermore, the use of flashlights and campfires may interfere with seafinding behavior by hatchlings. Beach driving by off-road vehicles may harm sea turtles by running over nests, which may increase sand compaction and decrease hatching success or kill pre-emergent hatchlings (NMFS and USFWS, 1991). Beach driving poses a risk of injury to females and live stranded turtles, can leave ruts that trap hatchlings attempting to reach the ocean (Hosier and others, 1981), can disturb adult females and cause them to abort nesting attempts, and can interfere with sea-finding behavior if headlights are used at night (NMFS and USFWS, 1991). Artificial lighting on human structures may affect turtle behavior in a similar manner (Martin and Witherington 1996). Beach cleaning can directly destroy nests. Poaching is a problem in some countries, and occurs at a low level in the United States.

Indirect Effects. - An increased human presence may lead to an increase in the presence of domestic pets that can depredate nests, and an increase in litter that may attract wild predators (National Research Council, 1990). Pedestrian and ORV traffic and beach-cleaning activities can create ruts that trap emerging hatchling and prevent them from finding the sea (Hosier and others, 1981). Trampling can increase sand compaction that may damage nests or hatchlings (Kudo and others, 2003). When artificial lighting impairs sea-finding behavior of nesting females and emerging hatchlings, the affected animals face increased exposure to the elements and predation. 
The rate of habitat loss due to erosion and escarpment may be increased when humans attempt to stabilize the shoreline, either through renourishment (Dolan and others, 1973), or placement of hard structures such as sea walls or pilings (Bouchard and others, 1998). ORV traffic may alter the beach profile, leading to steeper foredunes (Anders and Leatherman, 1987), which may be unsuitable for nesting. Improperly placed erosioncontrol structures such as drift-fencing can act as a barrier to nesting females. Humans may also introduce exotic vegetation in conjunction with beach development, which can overrun nesting habitat or make the substrate unsuitable for digging nest cavities.

\section{Threats at CAHA}

The following data are from CAHA sea turtle monitoring reports, 1999-2003. The majority of nest losses at CAHA from 1999 to 2003 were due to weather, particularly hurricanes and other storms. In 2003 Hurricane Isabel destroyed so many nests that losses to other sources were difficult to document. Foxes were first seen at CAHA in 1999, and on Hatteras Island in winter 2001-2002. Foxes disturbed or destroyed 1 to 9 nests/yr from 1999 to 2003, except in 2000 when no predation was reported. Ghost crab predation has been reported sporadically, with crabs seen at 0 to 17 nest sites/yr from 1999 to 2003 and observed predation of 0 to 3 nests/yr. Pedestrian tracks are recorded inside closures, and counts ranged from 8 to 92 trails/yr. Pedestrians disturbed or destroyed 2-6 nests/yr from 1999-2002 by digging them up, and none in 2003. Violation of closed areas by ORVs has become increasingly common, with 29 to 109 sets of tracks inside closures and 4 to 146 incidents of fencing vandalism recorded/yr ORVs drove over 4-5 nests/yr from 2000-2002, although the nests survived. Dogs disturbed or destroyed 2 nests in 2000, and 5-60 sets of tracks/yr have been recorded inside closures. Cats have not been observed to predate eggs or hatchlings, but 10 to 50 sets of tracks/yr were counted inside closures from 2000-2002. Documented beach campfires totaled 174 in 2000 and 773 in 2001. Such fires may misdirect adults and emergent hatchlings. Several cases of hatchlings being misdirected by lights from villages and other human structures were documented in 1999, 2000, and 2002.

\section{Current Monitoring and Protection at CAHA}

CAHA has been monitoring sea turtle nesting since 1988, from June 1 to September 1, although the North Carolina Wildlife Resources Commision (NCWRC) currently encourages turtle monitors to begin surveying on May 1 (M. Godfrey, NCWRC, pers. comm), and sea turtle hatching may occur through November 15. CAHA otherwise follows monitoring and management procedures outlined in the Handbook for Sea Turtle Volunteers in North Carolina (North Carolina Wildlife Resources Commission, 2002; Altman and Lyons, 2003).

Since 2004, ORV traffic is restricted year-round to a 50-m-wide corridor parallel to the shoreline, bounded at one side by the average high water line. Vehicles may drive along or park within the corridor. Where there is a primary dune line, this corridor effectively extends to the dune toe in most places. Thus, little to no ocean backshore nesting habitat is free of pedestrian and ORV use except where specific areas are closed to protect sea turtle or bird nests. Pedestrians, but not pets, are permitted outside the ORV corridor on the spits, except where there are specific "resource closures."

As of 2005, monitoring to detect crawls and dig sites was conducted each day at dawn, from June 1 to September 1. When a nest was found, a buffer zone of symbolic fencline was placed around it, approximately $9 \mathrm{~m}$ on a side. As the hatching date approached, the buffer zone width was expanded to $23 \mathrm{~m}$ in low-recreation areas, $46 \mathrm{~m}$ adjacent to villages or areas with high day use, and $107 \mathrm{~m}$ in ORV zones. Furthermore, the closures were extended to the surf line to prevent further traffic between the nest and the sea, and to $15 \mathrm{~m}$ landward of the nest, and vehicle tracks between the nest and the sea were mechanically smoothed. Drift fences were placed behind nests to shield emerging hatchlings from headlight beams, and ORV traffic was directed landward of these fence lines. A small number of nests were relocated due to impending threat of overwash or erosion. In past years, relocations also occurred if nests were laid close to artificial light sources such as piers. 
In some years prior to 2005, predator exclosure screens were placed over nests to prevent red fox predation. From 2002-2005 the NPS undertook trapping to remove mammalian predators from Bodie Island and Hatteras Island. In 2002, 12 red foxes were removed from Hatteras Island by U.S. Dept. of Agriculture (USDA) Wildlife Services personnel, and another 16 from Bodie Island. USDA officials believed there was still one fox left near South Beach, and a number of foxes on Bodie Island. In 2003, 15 foxes were removed from Bodie Island and 1 from Hatteras, as well as three opossums and one raccoon at Hatteras. CAHA staff removed one feral cat from near Hatteras Inlet. Although a number of foxes were still believed to be on Bodie Island, no fox tracks were seen in plover habitat after trapping began in 2002. Predator removal may enhance the success of exclosures.

CAHA staff proposed initiatives to use concessionaire fees to purchase turtle-friendly lighting for piers (Altman and Lyons, 2003).

Effects of current management.- There is a high risk of disturbance or injury to adult females and stranded individuals due to night recreation and ORV driving, including deterrence from nesting. Starting monitoring on June 1 leads to nests laid earlier being missed, and ending on September 1 may lead to insufficient protection for hatchlings after that date. Furthermore, nests may be missed by monitors if ORV ruts obscure turtle crawls, and other nests may be missed because the amount of habitat that monitors must search at CAHA is great (55 miles/day, Altman and Lyons, 2003). Unfound nests are at high risk of being crushed by ORVs or pedestrians, as are any other nests that are laid between nest surveys. The small size of the buffer zones used to protect nests leads to a risk that trespassing by people or domestic animals in protected areas will affect the nest itself. The presence of ORVs on the beach at night leads to the risk of deterred nesting and misdirection and disorientation of emerging hatchlings, which in turn leads to an increase risk of hatchling loss due to crushing by humans or becoming trapped in ruts, and due to predation and the elements. Campfires and artificial lighting on human structures, especially at the villages, may deter nesting or affect the seafinding hatchlings. The presence of ORVs $24 \mathrm{~h} /$ day year round may affect the beach profile and substrate characteristics in a way that reduces suitability for nesting and reduces emergence success. The use of predator screens may have attracted foxes to particular nests in 2001 and 2003, and resulted in the loss of a nest in 2003 because a screen was improperly placed (Altman and Lyons, 2003). However, the screens have generally only been used when the risk of depredation by foxes was already known to be high, and in 2001 reduced the number of eggs lost even when a fox attempted to dig through a screen (Sayles, 2002). Predator screens have been shown to reduce nest depredation in other places (Adamany and others, 1997; Ratnaswamy and others, 1997).

\section{Adaptive Resource Management}

Monitoring of floral and fauna over large landscapes should always include three components: a research question(s) aimed at a desired goal, a management approach or experiment to try to determine causality, and a monitoring component to determine the resultant magnitude, duration, and latency of changes associated with the management action or experiment. As monitoring results are revealed, a feedback loop allows the manager to either continue the current management practice or technique, or modify it until the desired trajectory is achieved.

CAHA is at or near the northern limit of the breeding range for all three species of sea turtle that nest there. As such, it may be difficult to manage the current populations for increased nesting density, especially for the green and leatherback turtles. For the latter two species, the primary management goals should be to accurately assess the number of nesting females and their reproductive success so that the current contribution of CAHA to regional population dynamics can be better understood, and to continue to protect adults and nests wherever they are found. Some have suggested, however, that as populations of green and leatherback turtles increase in the western Atlantic, they are expanding their range, and thus populations in North Carolina could increase in the future (M. Godfrey, NC Wildlife Resources Commision, per. comm.). For the more numerous loggerhead, factors affecting distribution and abundance, and especially the effectiveness of recreation man-

agement, can be studied and the results used to enhance management. Data collected to that end should still be collected for green and leatherback turtles, in the event that numbers of those species increase. The baseline 
level of recreational use of sea turtle habitat has not been quantified, and should be studied if management to reduce recreational impact is desired.

\section{Questions to Be Addressed}

1. How many nests of each species are found per year and what is their location?

2. What is the hatching success for each species?

3. What is the sea-finding success rate for hatchlings of each species?

4. What is the fate of nests that are relocated?

\section{Adaptive Management Protocols}

Objective 1: To determine the effect of management of human recreation on nesting rate, hatching success, sea-finding by hatchlings (prevalence of misorientation and trapping by obstacles), proportion of false crawls, presence of potential predators and their tracks or burrows (mammalian, avian, and ghost crabs), and nest site characteristics (intertidal zone slope, backshore slope, $\%$ vegetation in the backshore, distance from nests to tide line, distance from nest to dune, sand grain size in ITZ and backshore).

Proposal: Closure of 20 2-km beach segments to ORVs and pedestrians from April 1 (to allow the beach to return to more natural conditions before the nesting season) to November 15. Compare aforementioned variables between the treatment segments and 39 control segments that are managed according to Option B or Option C below. All segments in the experiment should be chosen in areas where turtles have nested in the last 10 years (i.e., exclude northern portions of CAHA where turtles rarely or never nest). The experiment should be replicated for several years, at least until nesting rate in the control segments equals the 10 year average of $0.7 \mathrm{nest} / \mathrm{km}$. Improving the power of the test to detect an effect at a lower baseline nesting rate would require greatly increasing the number of beach segments that are closed to ORVs, which would likely entail collaboration with other nearby parks where ORVs are typically permitted (e.g., Cape Lookout National Seashore). Alternatively, with an increased number of beach segments (either within CAHA or with the addition of other parks), several management options could be tested simultaneously. We recommend at least 20 2-km beach segments per management option tested, with at least 39 control segments.

If a significant effect of recreation is found, recreational restrictions in the experimental and control segments can be varied systematically to distinguish the effects of pedestrians from ORVs and the effect of time of day when recreation occurs. As an example, under management Option B with no nightime pedestrian recreation as a sub-option, this experiment will be testing the combined effect of daytime ORV and pedestrian recreation. If an effect is detected, in the next round of experiments the specific effect of ORVs can be examined by allowing pedestrians into the treatment segments during the day. On the other hand, if no effect is detected then the next round of experiments could entail switching to Option $\mathrm{C}$ in the control areas, to determine the combined effect of 24-hour ORV and pedestrian recreation. Decrease in sea turtle protection in any portion of CAHA for purposes of management experiments should not occur without the permission of the USFWS and the North Carolina Wildlife Resources Commission (NCWRC), on a case by case basis.

Objective 2: To determine the effect of artificial light management on nesting rate and hatchling orientation.

Proposal: Compare proportion of false crawls and hatchling misorientation incidents within $500 \mathrm{~m}$ and $1,000 \mathrm{~m}$ of artificial light sources on human structures before and after turtle-friendly lighting regulations or initiatives are enacted. 


\section{Additional Research to Address Management Goals}

Question 1: How is the detectability of turtle nests by monitors affected by changes in observers, species, presence of vehicles, environmental conditions, and time of day?

Proposal: Lay down artificial tracks for each species from May 15 to September 1 at a rate and density similar to the nesting rate of each species at CAHA (for loggerheads, 1 nest $/ 1.2$ days spaced at 1 nest $/ 1.4 \mathrm{~km}$, perhaps varying the rate somewhat to mimic peak nesting). Lay the artificial tracks at randomly selected times between sunset and sunrise. Record species mimicked, sunset and sunrise time, time tracks are laid, whether there is ORV access, wind speed and direction, and indicators of precipitation (yes or no, heavy or light, proportion of the night that it rained). Record the locations of each artificial crawl with a GPS unit so they can be reliably distinguished from true nest attempts or crawls. Compare detection rates of artificial crawls on morning surveys, between ORV and no ORV areas, including the effect of hours after sunset that an artificial crawl was made, species, weather variables, and observer.

Question 2: What proportion of closure violations by pedestrians and ORVs occurs between sundown and sunrise?

Proposal: In 25 randomly chosen nest closures in the ORV areas, smooth over the sand at dawn. Survey these closures just before sundown for the presence of human, ORV, and predator tracks, and vandalism of fencing and signs. Smooth the sand again and repeat the survey during the dawn monitoring on the following day. Replicate the survey 10 times during the nesting season, including Memorial Day and July 4th weekend. Estimate the proportion of violation events that occur at night.

Question 3: How much ORV and pedestrian traffic occurs in turtle nesting habitat at CAHA, and how does this differ between day and night?

Proposal: Once $/ 3$ hrs for 10 minutes, count the number of ORVs driving through and stopping in the $591-\mathrm{km}$ beach segments designated in the protocol for adaptive management objective 1, and the number of people seen in each segment, recording the time of day, length of stay of each ORV and whether ORVs were seen in intertidal, backshore, or dune zones, so that the "total ORV hours" can be calculated for both driving and stationary vehicles in major beach habitat types. Perform these surveys one weekday and one weekend day/month from May 15 to September 1, plus once on each major holiday. If possible, perform the survey a second time each month, such that one fair weather day and one foul weather day is surveyed each month.

Question 4: How does nest relocation affect hatching success and sex ratio, and how do the results vary by location and crew member?

Proposal: Compare hatching success and incubation time between relocated nests and natural nests that were laid at the same time. Incubation time, like sex ratio, is directly related to nest temperature (Godfrey and Mrosovsky, 1997). Therefore, sex ratio is correlated with incubation time. Record the identity of all staff involved in disturbing and relocating each nest, and the geographic coordinates of the original and new nest location.

\section{Protection Recommendations}

We provide three management options for sea turtles and their nesting habitat, presented in order of increasing predicted negative effect on sea turtles. Since the sea turtle habitat at CAHA is dynamic and subject to change given weather, tides, and the continuous coastal processes of sediment erosion and accretion, some of the recommendations may become inapplicable for certain sites, or new sites may form that provide suitable sea turtle habitat. CAHA may modify the recommendations below based on expert knowledge of current field conditions, provided the modified protection meets or exceeds the spirit of the protocols. Once protections are put in place, we recommend that they not be later reduced without first consulting with the USFWS and NCWRC. 


\section{Option A: Highest Degree of Protection}

\section{Recommendations:}

1. Close all potential sea turtle nesting habitat (ocean intertidal zone, ocean backshore and dunes) to all recreational activites, $24 \mathrm{~h}$ /day, year round at the option of CAHA but at least from April 1 to November 15 or until the hatchlings from the last known sea turtle nest have emerged and entered the sea (whichever is later), wherever sea turtles nested, left false crawls, or otherwise attempted to nest from 1995-2005.

2. A 10-m buffer zone of signed, stringed symbolic fencing should be placed around all nests to reduce the risk of damage by essential vehicles or monitors.

3. Essential vehicles should drive in the intertidal zone at speeds not to exceed $10 \mathrm{mph}$, whenever possible. Essential vehicles should avoid driving in sea turtle habitat from sundown to sunrise unless absolutely necessary, and when driving in sea turtle habitat should be accompanied by a sea turtle monitor whenever possible.

4. Sea turtle monitors may conduct their activities by ORV. Whenever possible, they should drive only in the ocean intertidal zone, but avoid the wrack line, at speeds not to exceed $10 \mathrm{mph}$, to reduce potential effects on protected avian species. If monitoring must occur when the intertidal zone is not available, sea turtle monitors should consult with piping plover, colonial waterbird, oystercatcher, and seabeach amaranth monitors prior to entering the field to reduce the risk of harm to these species (hereafter "other protected species").

5. For all nests $>50$ days into incubation, all vehicle tracks should be smoothed nightly between the nest and the sea. Essential vehicles should make extra effort to not drive in the vicinity of a nest from 50 days until hatch, but if it is necessary they should not drive between the nest and the sea, and should consult with monitors for other protected species.

6. Continue trapping of potential nest and brood predators prior to the onset of the nesting season with the goal of removing all potential mammalian predators from the site, including the removal of all foxes from Hatteras Island and the prevention of their spread to Ocracoke Island. Removal of avian predators should be done by targeting problem individuals observed near sea turtle nests (Boarman, 2003), in the presence of a trained monitor. Avian predation can be further controlled by enforcing proper trash disposal and anti-wildlife feeding regulations (Boarman, 2003) throughout CAHA. Consult with a sea turtle monitor familiar with nest locations when trapping during the nesting period, to avoid disturbing nests. Trapping should be done by a trained professional with experience removing the species in question.

7. Protect nests with predator exclosures if nest predation becomes prevalent in a particular area. Monitor the exclosures for signs that predators are attracted to them.

8. Enact turtle-friendly lighting regulations for CAHA structures, and conduct outreach with adjacent communties toward the aim of enacting lighting regulations there. Examples of turtle-friendly lighting can be found in Witherington and Martin (1996). The goal of light management should be no artificial lights directly visible continuously in areas of the beach where adult turtles lay their eggs and hatchlings emerge. The Parks should follow through in its initiative to use concessionaire fees to purchase turtle-friendly lighting for fishing piers (Altman and Lyons, 2003) and also to identify problem lights in the beach communities and provide the homeowners with alternatives.

9. Relocate nests imperiled by impending erosion or flooding, according to guidelines in Handbook for Sea Turtle Volunteers in North Carolina (North Carolina Wildlife Resources Commission, 2002).

10. Assist stranded turtles according to the guidelines in the Handbook for Sea Turtle Volunteers in North Carolina (North Carolina Wildlife Resources Commission, 2002).

11. Outside of the restricted period detailed in Option A, Item 1, closures may be lifted unless doing so would conflict with protocols for other protected species in a particular area. 


\section{Predicted effects:}

There will be almost no risk of direct recreation-related injury, mortality, or disturbance to sea turtles within the boundaries of CAHA, and no recreation-related habitat alteration during the nesting season itself. Outside of the nesting season, ORV traffic may alter the beach profile and sediment characteristics and lead to decreased nesting rates or emergence rates, if CAHA opts not to enact year round closure. Visitation to other areas of CAHA may attract potential predators such as raccoons that may then enter sea turtle habitat. Essential vehicle use of sea turtle habitat and ORV-based monitoring entail slight risks of a nest or hatchlings being crushed, and of disturbance to nesting females. Predator trapping may result in disturbance to females or hatchlings, or nest or hatchling loss if the trappers are not cognizant of the location of the nests. Nest exclosures entail a slight risk of damaging eggs during placement, and may result in full or partial nest losses if a predator learns to hunt at them. If made of metal, nest exclosures can alter the magnetic field of sea turtle hatchlings, with unknown consequences (Irwin and others, 2004). Nest relocation entails disturbance of an existing nest, and may result in the loss of eggs or entire nests. Nest relocation may also results in decreased incubation periods that likely indicate an increased female bias in the sex ratio of the hatchlings produced by the relocated clutch (Rush, 2003).

\section{Option B: Moderate Protection}

\section{Recommendations:}

1. Close all potential sea turtle nesting habitat (ocean intertidal zone, ocean backshore and dunes) at CAHA to ORV traffic from sunset to sunrise (or until the morning sea turtle monitoring in a particular area has occurred for the day, whichever is later) from April 1 to November 15 or until the hatchlings from the last known sea turtle nest have emerged and entered the sea (whichever is later) wherever sea turtles nested, left false crawls, or otherwise attempted to nest from 1995-2005. Pedestrians may be allowed in sea turtle habitat at night at the option of CAHA, but pets should be prohibited at night (and during the day, at the option of CAHA). Pedestrians should be prohibited from sea turtle habitat at night in any area where nighttime closure is recommended in the protocols of other protected species.

2. Prohibit wildlife feeding and trash disposal in sea turtle habitat, $24 \mathrm{~h} /$ day, year-round.

3. If pedestrians are allowed on the beach at night, they should first be required to participate in an educational program on proper conduct in the habitat of protected species.

4. Close segments of sea turtle habitat to recreation $24 \mathrm{~h}$ /day during the period detailed in Option B, Item 1 , as per adaptive management protocol objective 1 .

5. Prohibit artificial light sources, including electric lights, campfires, and fireworks from all sea turtle nesting habitat during the restricted period described in Option B, item 1, with the following exceptions:

i. Pedestrian recreationists in sea turtle habitat at night may use light sources with red filters (these could be rented or sold by CAHA or concessionaires).

ii. Essential vehicles should use the bare minimum of lighting necessary for the performance of their duties, including performance of the sea turtle management activities recommended in these protocols.

6. Throughout CAHA, narrow the current 50-m ORV corridor such that a zone of ocean backshore at least $10 \mathrm{~m}$ wide and running the length of the site is free of ORV traffic. This zone should be adjacent to the toe of the primary dune wherever a primary dune exists (i.e., recreation should be restricted to a corridor between the mean high tide line and the edge of the zone of protected backshore).

7. A 50-m buffer zone of signed, stringed fencing should be placed around each nest in any place where recreation occurs. Random spot checks should be made at these closures during the day and at night to detect and prevent violations by recreationists. If $>3$ violations of the protected area around a particular nest are observed (including vandalism of the string itself), the buffer distance should be expanded to $100 \mathrm{~m}$, then to $200 \mathrm{~m}$ if necessary. Where recreation does not occur, a 10-m buffer zone should be used to prevent harm by essential vehicles. 
8. For all nests $>50$ days into incubation, in areas where recreation occurs expand the buffer zone to 200 $\mathrm{m}$ and smooth all ORV tracks between the nest and the sea each evening.

9. Enact recommendations 3-11 under Option A above.

\section{Predicted effects:}

If pedestrians are permitted on the beach at night there will be a low risk of disturbance to nesting females, or accidental or intentional destruction of nests or hatchlings, outside of closed areas. However, in the absence of ORV access the level of pedestrian use will likely be low, especially if the lighting restrictions are enforced. During the day, there is a risk that pedestrians or ORVs will intentionally or accidentally destroy nests. The presence of recreationists outside of closed areas may attract potential sea turtle nest and hatchling predators, and if pets are not banned during the day there is a risk that they will enter closures and disturb nests if the leash law is not strictly enforced. ORV use in unprotected areas may alter the beach profile and sediment characteristics in a manner that decreases nesting rate or hinders emergence. Potential effects of essential vehicle use, monitoring, and predation control are the same as for Option A.

\section{Option C: Minimum Protection}

\section{Recommendations:}

1. Throughout CAHA, require all recreationists (including ORV operators and passengers) that wish to enter sea turtle habitat at night to first participate in an educational program, as detailed in Option B, Item 3.

2. Throughout CAHA, prohibit pets from entering sea turtle habitat at night (and during the day, at the Park's option), and prohibit trash disposal and wildlife feeding $24 \mathrm{~h} /$ day year-round.

3. Throughout CAHA, for all nests $>50$ days into incubation, close the beach for $1,000 \mathrm{~m}$ on either side of the nest to ORV traffic. This will reduce the risk that headlights will affect emerging hatchlings.

4. Close segments of sea turtle habitat to recreation $24 \mathrm{~h}$ /day during the period detailed in Option B, Item 1 , as per adaptive management protocol \#1.

5. Prohibit artificial light sources, including electric lights, campfires, and fireworks from all sea turtle nesting habitat during the restricted period described in Option B, item 1, with the following exceptions:

i. Pedestrian recreationists in sea turtle habitat at night may use light sources with red filters (these could be rented or sold by CAHA or concessionaires).

ii. ORVs must turn off their headlights or place red filters over their headlights whenever they are parked.

iii. Essential vehicles should use the bare minimum of lighting necessary for the performance of their duties, including performance of the sea turtle management activities recommended in these protocols.

6. Enact recommendations 6-9 under Option B above.

\section{Predicted effects:}

Outside of closed areas, there is a high risk of disturbance or injury to females emerging from the ocean, digging nests, or laying eggs. There is a high risk of destruction of nests before they are located by monitors. There is a moderate risk of injury to hatchlings and of misdirection or disorientation of hatchlings due to headlights. Daytime effects of recreation are the same as for Option B and effects of management and essential vehicles. 


\section{Monitoring}

The goal of monitoring is to estimate the number, distribution, and fate of nests for each species. Continue to follow the monitoring and reporting guidlelines in the Handbook for Sea Turtle Volunteers in North Carolina (North Carolina Wildlife Resources Commission, 2002). Since some nests are missed by June 1 (Altman and Lyons, 2003), we recommend starting monitoring on May 1 as encouraged by the NCWRC, and as early as April 1 if evidence for missed nests continues to be found. The following information should continue to be collected during nest checks:

1. Date and time

\section{Species}

3. Sequential nest number

4. Whether a nest was relocated, the original and relocation site names, and the coordinates of the original and relocation sites, in UTM coordinates.

5. Distance from the nest to the tideline, dune, nearest fixed artificial light source, nearest vegetation, in meters

6. Nest inventory data, date when an inventory is conducted

7. Dates of nest overwash

8. Sources of egg or whole nest loss, if apparent

In addition, we recommend the following data be collected:

9. Geographic coordinates of false crawls when first found

10. Recreation management strategy in area where nest was found (e.g., ORV closure)

11. Intertidal zone, backshore, and dune slope and dune elevation (where applicable) at nests and false crawls when first found

12. Percent ground cover of vegetation at nests when first found

13. Number of potential predators, including ghost crabs, and pedestrians and ORVS within $100 \mathrm{~m}$ of the nest, daily

14. Number of tracks of potential predators, and pedestrians and ORVs, within $100 \mathrm{~m}$ of the nest, including ghost crab burrows, daily

15. Sediment grain size of samples collected at nest sites and the terminus of false crawls when first found. Samples should be collected at the surface and mid-nest depth, $1 \mathrm{~m}$ from nest sites along a line parallel to the tide line, outside of where the turtle has disturbed the sand if possible.

These additional data will assist managers in assessing potential threats to individual nests and to act before harm occurs. They will also facilitate understanding of the effects of recreation management on nesting habitat.

\section{Law Enforcement}

If a monitor observes a potential infraction of the law that threatens a turtle adult, nest, or hatchling, the relevant law enforcement personnel should be immediately contacted from the field, if possible. Otherwise, the monitor should leave the field as soon as possible and contact law enforcement.

If the scene of a past violation is discovered (such as a nest destroyed by a pedestrian), the scene should be left intact and the following information should be recorded: 
- Date and time

- Weather and tide conditions

- Location (Use a GPS unit to record the location). Plant a survey flag or other marker to assist in relocating the site. This should be a colored, easy to see marker.

- Nest number if given

- Number of adults, nests, eggs, and/or hatchlings involved

- Behavior of adult or hatchling, if relevant

- Condition of adult, nest, eggs, or hatchlings

- Hand-drawn map showing adult, nest, and/or hatchlings, symbolic fence line, predator, pedestrian, and/or ORV trails, other evidence, and nearby landscape features (e.g., tide line, dune line). If possible, use gridded paper so map scale can be indicated.

- Photographs of the evidence

The relevant law enforcement personnel should be contacted as soon as possible and provided with a copy of the incident record. While gathering of information by a lay person may compromise the scene to some degree, the ephemeral nature of evidence in beach environments requires immediate collection of some basic data.

\section{Reporting Procedures}

The data collected in the field have many potential uses and applications. For nesting location data, GPS locational information needs to be conveyed as quickly as possible to Resource Management staff in order to implement protection measures. Similarly, witnessing violations of closure areas or other illegal activities needs to be conveyed to Law Enforcement staff as soon as possible. If violations of federal or state regulations are confirmed, notification needs to be made to the U.S. Fish and Wildlife Service-Raleigh Field Office and the North Carolina Wildlife Resources Commission as appropriate.

The field data should be collected in two forms: in field books as narrative accounts, and on field data forms developed in conjunction with other partner agencies, scientists and managers. Field forms should be quality checked by an independent reader, comparing field notebooks and forms where appropriate (see section below). When verified, the data should be electronically entered, analyzed where needed, summarized in reports in text, tabular and graphic form, and submitted to both CAHA administrative personnel and other cooperating agency personnel and other scientists and managers as requested. Reports should be available both in electronic form (pdf preferred) and in limited numbers of hard copy.

\section{Data Management}

\section{Raw Data Collection}

Field data sheets should include, at a minimum, the date, the reference location (GPS and usually a code number), a point or specific area, and observer name or initials. Because of the large amount of data included in these different data collection efforts, we strongly urge that all individuals engaged in data collection be trained in advance of the actual data collection period. Regardless of how clear a field form appears to be, questions always arise about how to record certain types of data. 


\section{Data Entry}

Because the National Park Service (as well as other agencies) has determined that Microsoft Access will be the official database management software in the monitoring programs, we recommend it as the primary management tool. In some cases, Excel spreadsheets may be used since this is what the cooperators/contractors often provide. However, conversion of Excel to Access is not difficult and the structure of the tables is quite similar.

One advantage of Access includes efficiency, because many fields of data (location, physical parameters) need not be reentered on each successive survey, and flexibility in presentation. Links can be made among tables of physical parameters, nesting rate estimate, hatching success, etc.

\section{Metadata}

The metadata are best structured as separate components as the resource and scientific community needing different aspects of the data are quite different. Quality assurance and quality control are best maintained by having the field data reviewed and entered into the database on the same day it is collected. Two individuals should first review the data to reduce error propagation. Generally it is best to have the person collecting the data also doing the data entry, followed by having a second person compare the computer printout with the original field sheets. This second step can be done at a later date to reduce fatigue on field days.

\section{Data Storage}

Field data sheets should be stored in a safe, low-fire-risk location in or near the NPS Headquarters in Manteo. Upon entry into a PC's electronic Access database, an extra copy of the database should be generated on a separate portable hard drive, or on CDs which then should be maintained in a separate building. If a computer network is available at the site, the files can be more easily transferred electronically to other PC sites, rather than having to physically transfer media between locations. Security demands by the NPS may require extra steps in the data management outlined here.

\section{Data Analysis Techniques}

The methods for analyzing the data will vary greatly depending upon the question and the level of analysis of interest. Excellent statistical support and advice is available both at the USGS Patuxent Wildlife Research Center (Drs. Jim Nichols, James Hines, John Sauer, William Kendall, Michael Runge, and Jeff Hatfield) and at NC State University (Dr. K. Pollock associated with the NC Cooperative Wildlife Research Center), and we recommend consulting with other statisticians that are familiar with sea turtle databases. Biologists at CAHA should consult with one or more statisticians whenever statistical analyses are to be conducted. Many population and metapopulation models are already available online from Patuxent (see http:// www.pwrc.usgs.gov), but usually these require some discussion with statisticians beforehand.

\section{Education and Outreach}

Continue posting all symbolic fence lines with signs that clearly indicate the species being protected. Post signs detailing turtle biology and the reasons for protecting the species at points where visitors are likely to first encounter restricted areas.

Provide visitors with postcards and informational brochures that contain information on turtles and the biological and legal reasons for their protection at CAHA. Interpretive walks in which visitors are guided to nest sites during the day and shown turtle crawls, and shown videos of nesting adults and hatching nests can also be a useful outreach mechanism, since untrained visitors may never otherwise see these species due to their nocturnal habits. 
Advertise turtle protection efforts and management successes in local papers and magazines and write educational articles for these outlets. Gain the confidence of a skilled writer/reporter in what you are doing. Ask that all articles that reporters write be checked by a manager or biologist so that corrections can be made if errors are found.

Staff training.-Provide training to all CAHA staff including sign crew, patrol, maintenance crews, etc. on behavior and monitoring techniques for sea turtles. This training should also include turtle identification, safe vehicle operations within sea turtle habitat and limiting activities in habitat.

Turtle monitors themselves need to have a subset of skills and knowledge before entering the field independently. These ideally include:

1. Ability to identify the adults, nests, and young of all protected species by sight, sound, and track evidence

2. Ability to identify sea turtle nesting behavior by sight and by sign (e.g., crawls)

3. Familiarity with the CAHA protocols for management and protection of each species

4. Basic knowledge of the laws protecting each species

5. Understanding of the process for dealing with and reporting legal infractions and injured wildlife

6. Clear understanding of Park policies for interacting with members of the public, the press, etc., and enough basic knowledge of the biology of each species to permit such interactions to be positive and informative.

\section{Acknowledgments}

Funding for this Protocol was provided by the U.S. Geological Survey, Patuxent Wildlife Research Center, under USGS Cooperative Agreement number 1434-00 HQRV1573, Research Work Order 104. Special thanks to Ruth Boettcher, Matthew Godfrey, Sandy MacPherson, and David Rabon for reviews of these protocols. Administrative review was also provided by the following NPS personnel: Sherri Fields and Steve Harrison, and by Dr. J.B. French, USGS Patuxent Wildlife Research Center.

\section{Selected References}

Adamany, S.L., Salmon, M., and Witherington, B.E., 1997, Behaviour of sea turtles at an urban beach III. Costs and benefits of nest caging as a management strategy: Florida Scientist, v. 60, no. 4, p. 239-253.

Altman, J., and Lyons, M., 2003, 2003 sea turtle summary, breeding and stranding activities, Cape Hatteras National Seashore: Buxton, North Carolina, National Park Service, unpublished annual report, 16 p.

Anders, F., and Leatherman, S., 1987, Disturbance of beach sediment by off-road vehicles: Environmental Geology and Water Sciences, v. 9, no. 3, p. 183-189.

Boarman, W.I., 2003, Managing a subsidized predator population: reducing common raven predation on desert tortoises: Environmental Management, v. 32, no. 2, p. 205-217.

Bollmer, J.L., Irwin, M.E., Rieder, J.P., and Parker, P.G., 1999, Multiple paternity in loggerhead turtle clutches: Copeia 1999, no. 2, p. 475-478.

Bolten, A.B., 2003, Active swimmers - passive drifters: the oceanic juvenile stage of loggerheads in the Atlantic System (pages 63-78) in Bolten, A.B., and Witherington, B.E., eds., Loggerhead sea turtles: Washington, D.C., Smithsonian Books, 319 p. 
Bouchard, S., Moran, K., Tiwari, M., Wood, D., Bolten, A., Eliazar, P.J., and Bjorndal, K.A., 1998, Effects of exposed pilings on sea turtle nesting activity at Melbourne Beach, Florida: Journal of Coastal Research, v. 14 , no. 4 , p. $1,343-1,347$.

Bowen, B.W., Bass, A.L., Soares, L., and Toonen, R.J., 2005, Conservation implications of complex population structure: lessons from the loggerhead turtle (Caretta caretta): Molecular Ecology, v. 14, no. 8, p. 2,389-2,402.

Carthy, R.R., Foley, A.M., and Matsuzawa, Y., 2003, Incubation environment of loggerhead turtle nests: effects on hatching success and hatchling characteristics (pages 144-154) in Bolten, A.B., and Witherington B.E., eds., Loggerhead sea turtles: Washington, D.C., Smithsonian Books, 319 p.

Dolan, R., Godfrey, P.J., and Odum, W.E., 1973, Man's impact on the barrier islands of North Carolina: American Scientist, v. 61, p. 152-162.

Ehrhart, L.M., Bagley, D.A., and Redfoot, W.E., 2003, Loggerhead turtles in the Atlantic Ocean: geographic distribution, abundance, and population status (pages 157-174) in Bolten, A.B., and Witherington B.E., eds., Loggerhead sea turtles: Washington, D.C., Smithsonian Books, 319 p.

Godfrey, M.H., and Cluse, W.M., 2003, Sea turtle project of North Carolina: Poster presentation, 23rd Symposium on Sea Turtle Biology and Conservation, March 17-21, 2003, Kuala Lumpur, Malaysia.

Godfrey, M.H., and Mrosovsky, N.,1997, Estimating the time between hatching of sea turtles and their emergence from the nest: Chelonian Conservation and Biology, v. 2, no. 4, p. 581-585.

Hosier, P.E., Kochhar, M., and Thayer, V., 1981, Off-road vehicle and pedestrian track effects on the seaapproach of hatchling loggerhead turtles: Environmental Conservation, v. 8, no. 2, p. 158-161.

Irwin, W.P., Amy J.H., and Lohmann, K.J., 2004, Magnetic field distortions produced by protective cages around sea turtle nests: unintended consequences for orientation and navigation? Biological Conservation, v. 118, no. 1, p. 117-120, doi: 10.1016/j.biocon.2003.07.014.

Kudo, H., Murakami, A., and Watanbe, S., 2003, Effects of sand hardness and human beach use on emergence success of loggerhead sea turtles on Yakushima Island, Japan: Chelonian Conservation and Biology, v. 4, no. 3, p. 695-696.

Lohmann, K.J., and Lohmann, C.M.F., 2003, Orientation mechanisms of hatchling loggerheads (pages 44-62) in Bolten, A.B., and Witherington B.E., eds., Loggerhead sea turtles: Washington, D.C., Smithsonian Books, 319 p.

Miller, J.D., Limpus, C.J., and Godfrey, M.H., 2003, Nest site selection, oviposition, eggs, development, hatching, and emergence of loggerhead turtles (pages 125-143) in Bolten, A.B., and Witherington B.E., eds., Loggerhead sea turtles: Washington, D.C., Smithsonian Books, 319 p.

Mrosovsky, N., Hopkins-Murphy, S.R., and Richardson, J.I., 1984, Sex ratio of sea turtles: seasonal changes: Science, v. 225, p. 739-741.

National Park Service, 1999, 1999 sea turtle breeding and stranding summary, Cape Hatteras National Seashore, accessed September 2009 at http://www.nps.gov/caha/seaturt.htm.

National Park Service, 2005, Park visitation report: National Park Service, Public Use Statistics Office, Denver, Colorado, accessed December 10, 2009 at http://www2.nature.nps.gov/stats/.

National Research Council, Committee on Sea Turtle Conservation, 1990, Decline of sea turtles: causes and prevention: Washington, D.C., National Academy Press, 259 p.

North Carolina Wildlife Resources Commission, 2002., Handbook for sea turtle volunteers in North Carolina: Raleigh, North Carolina, North Carolina Wildlife Resources Commission, 45 p. 
Rabon, D.R., Jr., Johnson, S., Boettcher, R., Dodd, M., Lyons, M., Murphy, S., Ramsey, S., Roff, S., and Stewart, K., 2003, Confirmed leatherback turtle (Dermochelys coriacea) nest from North Carolina, with summary of leatherback nesting activities north of Florida: Marine Turtle Newsletter, no. 101, p. 4-8.

Ratnaswamy, M.J., Warren, R.J., Kramer, M.T., and Adam, M.D., 1997, Comparisons of lethal and nonlethal techniques to reduce raccoon depredation of sea turtle nests: Journal of Wildlife Management, v. 61, no. 2, p. $368-376$.

Rush, M.D., 2003, An evaluation of nest relocation as a loggerhead sea turtle (Caretta caretta) management technique in North Carolina: Durham, North Carolina, Duke University, Nicholas School of the Environment and Earth Sciences, M.S. thesis, 126 p.

Sayles, K, 2002, 2001 Sea turtle summary, breeding and stranding activities, Cape Hatteras National Seashore: Buxton, North Carolina, National Park Service, unpublished annual report, 12 p.

Schroeder, B.A., Foley, A.M., and Bagley, D.A., 2003, Nesting patterns, reproductive migrations, and adult foraging areas of loggerhead turtles (pages 114-124) in Bolten, A.B., and Witherington B.E., eds., Loggerhead sea turtles: Washington, D.C., Smithsonian Books, 319 p.

Snover, M.L., 2002, Growth and ontogeny of sea turtles using skeletenochronology: methods, validation, and application to conservation: Durham, North Carolina, Duke University, Ph.D. dissertation, 144 p.

Witherington, B.E., 2003, Biological conservation of loggerheads, challenges and opportunities (pages 295-312) in Bolten, A.B., and Witherington B.E., eds., Loggerhead sea turtles: Washington, D.C., Smithsonian Books, 319 p.

Witherington, B.E., and Martin, R.E., 1996, Understanding, assessing, and resolving light-pollution problems on sea turtle nesting beaches: Florida Marine Research Institute, FMRI Technical Report TR-2, 73 p., accessed December 10, 2009 at http://www.nests-certified.org/pdf/LightingTechReport.pdf. 


\title{
Chapter 5-Management, Monitoring, and Protection Protocols for Seabeach Amaranth at Cape Hatteras National Seashore, North Carolina
}

\author{
By Jeffrey L. Marion
}

\section{Species Description}

The seabeach amaranth (Amaranthus pumilus) is an annual plant, with no vegetative reproduction, in the Family Amaranthaceae native to the beaches of the Atlantic Coast (fig. 5-1). Historically the plant occurred in 31 counties of nine states from Massachusetts to South Carolina (USFWS, 1996). Currently seabeach amaranth is known from NY, $\mathrm{NJ}, \mathrm{DE}, \mathrm{MD}, \mathrm{VA}, \mathrm{NC}$ and $\mathrm{SC}$. The species was federally listed as Threatened by the U.S. Fish and Wildlife Service on April 7, 1993 (USFWS, 1993). Seabeach amaranth has a global rank of G2, (The Nature Conservancy). Within North Carolina

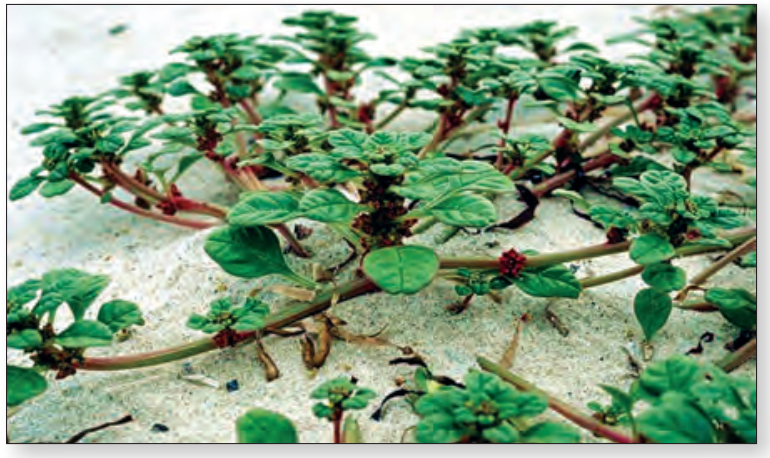

Figure 5-1. Seabeach amaranth (Amaranthus pumilus). Photograph by Stephen M. Young. numbers of plants increased from 2002 to 2003 from 5,700 to 9,366 plants along 112 miles of beach (Dale Suiter, USFWS). However, these numbers represent a fraction of the reports of approximately 40,000 individuals reported in the late 1980s and in 1995. For example, there were three to fifteen thousand individuals per year within Cape Hatteras National Seashore (CAHA) in the period 1987 to 1990 but only 50 to 133 individuals have been found in the period 2001 to 2003 (table 5-1).

The plants must recruit annually from seed banks either in situ or from other source populations dispersed by water, wind, or from on or offshore sediments distributed by anthropogenic factors (Jolls and others, 2004). Seeds must be scarified (the seed coat broken by nicking or abrasion, Hancock and Hosier 2003) or cold stratified (chilling for weeks) before germination of any magnitude can occur (Baskin and Baskin, 1998; Blazich and others, 2005; Jolls and others, 2001).

Germination takes place over a relatively long period of time, generally beginning in April and continuing at least through July (USFWS, 1996). Upon germinating, this plant initially forms a small unbranched shoot but soon begins to branch profusely into a clump, often reaching $30 \mathrm{~cm}$ in diameter and consisting of 5 to 20 branches (fig. 5-1). Occasionally a clump may get as large as a meter or more across, with a hundred or more branches. The stems are fleshy and pink-red or reddish, with small rounded leaves that are 1.3 to 2.5 $\mathrm{cm}$ in diameter. The leaves are clustered toward the tip of the stem, are normally a somewhat shiny, spinachgreen color, and have a small notch at the rounded tip. Flowers and fruits are relatively inconspicuous and are borne in clusters along the stems. Flowering begins as soon as plants have reached sufficient size, sometimes as early as June in the Carolinas but more typically commencing in July and continuing until their death in late fall or early winter. The plants are reported to be monoecious (having male and female flowers on the same plant) (USFWS, 1996). Seed production begins in July or August, reaches a peak in most years in September, and continues until the plant dies. The species is a prolific seed producer of waxy seeds which are relatively large $(2-2.5 \mathrm{~mm})$ and are believed to be viable for long periods (New Jersey Department of Environmental Protection, 2003). Seed dispersal may occur by wind, water and possibly birds, and whole plants and seeds are temporarily buoyant.

\section{Habitat Description}

The plant grows only on Atlantic Coast beaches, mainly on coastal overwash flats at the accreting ends of the islands and lower foredunes and on ocean beaches above mean high tide (occasionally on sound-side 
Table 5-1. Numbers of naturally occurring plants of $A$. pumilus at Cape Hatteras (CAHA) and Cape Lookout (CALO) National Seashores since 1985.

[Empty cells represent no data. Censuses were completed by a variety of personnel and agencies, typically in July and August. (From Jolls and others, 2004).]

\begin{tabular}{lcccccccccrrrr}
\hline \multicolumn{1}{c}{ Site } & $\mathbf{2 0 0 3}$ & $\mathbf{2 0 0 2}$ & $\mathbf{2 0 0 1}$ & $\mathbf{2 0 0 0}$ & $\mathbf{1 9 9 8}$ & $\mathbf{1 9 9 7}$ & $\mathbf{1 9 9 6}$ & $\mathbf{1 9 9 5}$ & $\mathbf{1 9 9 0}$ & $\mathbf{1 9 8 8}$ & $\mathbf{1 9 8 7}$ & $\mathbf{1 9 8 6}$ & $\mathbf{1 9 8 5}$ \\
\hline Hatteras Point & 16 & 45 & 37 & 1 & 9 & 59 & 2 & & 2,830 & 800 & 5,200 & 200 & \\
Hatteras Inlet & 2 & 75 & 16 & 1 & 47 & 16 & 62 & 0 & 252 & 1,718 & 274 & 300 & 450 \\
North Ocracoke & 36 & 13 & & & 0 & 6 & 14 & 1 & 250 & 13,310 & 1,409 & 100 & 100 \\
Totals & $\mathbf{5 4}$ & $\mathbf{1 3 3}$ & $\mathbf{5 3}$ & $\mathbf{2}$ & $\mathbf{5 6}$ & $\mathbf{8 1}$ & $\mathbf{7 8}$ & $\mathbf{1}$ & $\mathbf{3 , 3 3 2}$ & $\mathbf{1 5 , 8 2 8}$ & $\mathbf{6 , 8 8 3}$ & $\mathbf{6 0 0}$ & $\mathbf{5 5 0}$ \\
\hline
\end{tabular}

beaches) (NatureServe, 2005). It often grows in the same areas selected for nesting by shorebirds such as plovers, terns, and skimmers. It is intolerant of competition with other plants and does not occur on well-vegetated sites. According to Weakley and Bucher (1991), this species appears to need extensive, dynamic, natural areas of barrier island beaches and inlets. Within this dynamic landscape, A. pumilus functions as a fugitive species, occupying suitable habitat as it becomes available (NatureServe, 2005). Seeds may survive many years buried in the sand; they germinate when brought near the surface by overwash events or more severe storms.

The U.S. Fish and Wildlife Service Recovery Plan (1996) includes the following relevant information regarding this species' habitat requirements:

"One of the more striking features of the distribution of seabeach amaranth in the Carolinas is its near absence from the northern third of the North Carolina coast. From Cape Hatteras north, only two plants were found in each of the years 1987 and 1988. It is not currently known whether the virtual lack of amaranth in this area is related to natural or historic factors. A hypothesis emphasizing the importance of natural forces would note that the present North Carolina strongholds of seabeach amaranth appear, in general, to be the south-facing coast of Brunswick County, the south- and southeast-facing coasts of Carteret and Onslow Counties, and the south- and southeast-facing coasts of Dare and Hyde Counties. The east- or even northeast-facing coasts of Currituck, northern Dare, northern Carteret, and New Hanover Counties generally support smaller, more scattered populations of seabeach amaranth.

Dolan and Lins (1987) indicate that "the rate of shoreline erosion along the barrier islands of Virginia varies with the configuration of the shoreline. Erosion rates are highest where the shoreline faces northeast and lowest where it faces southeast." Greater erosion on east-facing beaches in the Carolinas may reduce seabeach amaranth habitat, compared to the south-facing beaches immediately west of each of the great capes (Hatteras, Lookout, and Fear). Long Island's (New York) Atlantic shore is also south-facing. Moreover, seabeach amaranth is (at least during periods of sea level rise) a species primarily of inlets, and Oregon Inlet is the only inlet from Cape Hatteras north to the North Carolina/Virginia line. An alternate hypothesis notes that the stretch of North Carolina from which seabeach amaranth is absent corresponds almost exactly with the construction of a continuous barrier dune by the National Park Service, Civilian Conservation Corps, and Work Projects Administration from the 1930s to 1950s. Dolan and Lins (1987) state:

Thirty years of artificial dune stabilization have altered the ecology and geology of the Outer Banks. A comparison of a cross section of Hatteras Island and Core Banks, representing the altered and natural states of barrier islands, shows how stabilization has changed the morphology and ecology of the beaches, dunes, and marshes. Viewed from the air, the most striking contrast between the natural and altered barrier islands, other than the artificial barrier dune, is a marked difference in beach width. Unaltered islands have beaches from 100 to $180 \mathrm{~m}$ wide, whereas on Hatteras Island the beach has been reduced to $30 \mathrm{~m}$ or less. The paradox suggests that manmade structures do not merely fail to protect beaches but actually work to destroy them.

We do not know whether seabeach amaranth was present here prior to artificial dune stabilization and was eliminated by its results. A species with a similar habitat, seabeach knotweed (Polygonum glaucum), was known from Chicamacomico, North Carolina, prior to the commencement of dune stabilization and 
has not been seen in recent years. No vascular plants regularly occur at a lower topographic position on beaches than seabeach amaranth, though several others - most notably, saltwort (Salsola australis) and sea rocket (Cakile edentula) - often occur with seabeach amaranth at the lowest elevations that support vascular plants. Seabeach amaranth occupies elevations from 0.2 to $1.5 \mathrm{~m}$ above mean high tide.

Christensen (1988) states that "strand vegetation consists of an assemblage of short-lived plants whose spatial distribution shifts from season to season and year to year. Many of these species are salt-tolerant and have life-history characteristics that allow them to invade suitable habitat when it becomes available." This natural community or vegetation type is classified by Schafale and Weakley (1990) as Upper Beach, although seabeach amaranth is sometimes found on sand spits $50 \mathrm{~m}$ or more from the base of the nearest foredune (Mangels, 1991, written commun.).

Seabeach amaranth appears to need extensive areas of barrier island beaches and inlets, functioning in a relatively natural and dynamic manner. This allows it to move around in the landscape, as a fugitive species, to occupy suitable habitat as it becomes available.

Populations of seabeach amaranth, like the habitat upon which it grows, are highly dynamic, with numbers of plants often fluctuating dramatically from one year to the next. The plants generally occur in a sparse to very sparse distribution pattern. The plants are often widely scattered, especially on upper beaches where the average density can be as low as one plant per kilometer. Because amaranth usually occurs in a zone about $10 \mathrm{~m}$ wide this translates to a density of one plant per hectare. A more typical beach density would be 10 plants per $100 \mathrm{~m}$ of linear beach (100 plants per ha), and occasionally, on accreting beaches, dense populations of 100 plants per $100 \mathrm{~m}$ of linear beach (1,000 plants per ha) can be found. Island-end flats generally have higher densities than beaches. The overall range of densities is about the same as on upper beaches (1 to 1,000 plants per hectare), but higher densities are encountered more often. Density is presumed to be determined by a complex set of factors, including previous year's seed set, seed bank, pattern of deposition of seeds by wind and water, weather conditions (especially rainfall) determining germination and survival of seedlings, predation by webworms, disturbance by human use, storms, and hurricanes.

This plant shares its beach habitat with a number of other rare species, both plant and animal. Seabeach knotweed, the purslanes (Sesuvium portulacastrum and S. maritumum), and seabeach morning-glory (Ipomoea imperati) are all considered rare within the Carolinas. A number of gulls, terns, skimmers, sandpipers, oystercatchers, and plovers also use this habitat for resting, roosting, or nesting. Included in this group are the State and/or federally listed piping plover (Charadrius melodus), least tern (Sterna antillarum), Wilson's plover (Charadrius wilsonia), black skimmer (Rhynchops niger), and Caspian tern (Sterna caspia). The endangered roseate tern (Sterna dougallii dougallii) also occurs in some of the same places. Some of the largest seabeach amaranth populations are associated with nesting sites of the least tern, Caspian tern, piping plover, or Wilson's plover. In the Carolinas, sea turtles also nest in this habitat; loggerheads (Caretta caretta) are the most common, but on rare occasions, green sea turtles (Chelonia mydas) also nest here. Both turtles are federally and State-listed as threatened."

Some notable studies have recently assessed habitat requirements and experimented with $\mathrm{A}$. pumilis recovery methods (Sellars, 2001; Sellars and Jolls, 2001; Jolls and others, 2004). A model developed by Sellars based on topographical factors, including highly accurate elevation measures obtained from LIDAR data, was used to predict $A$. pumilis occurrence and habitat with evaluations based on the occurrence of 164 plants in Carteret and Brunwick Counties, NC. This work found that elevation was the most limiting topographic variable controlling the occurrence of A. pumilis. Subsequent work used natural plant occurrences on Cape Lookout with a stepwise discriminant function analysis with grayscale (passive) LIDAR data to assess the role of vegetation cover. This work found that passive LIDAR (an index of bare sand) and elevation has been able to predict $72 \%$ of the plant occurrences and excluding $98 \%$ of the landscape as unsuitable habitat (Sellars and others, 2003).

These studies were extended in 2002-04 to Assateague Island and Cape Hatteras National Seashores. This study sought to develop a greater understanding of the species' ecology and to develop guidelines for $A$. pumilis re-introduction to historic or extirpated sites selected using remotely sensed data, GIS and a program of reintroduction from greenhouse/laboratory-reared plants (Jolls and others, 2004). Further modeling work using LIDAR data and known locations of plants for several years yielded estimates of total suitable habitat of 254 ha at CAHA. Inlet areas tended to have wider beaches and potentially greater A. pumilis habitat. 
Habitats delineated by the GIS modeling work were used to select sites for transplanting greenhouseraised plants both within and outside preferred habitats. Planting in "good" habitats was considered to be in the range of 0.77 and $2.00 \mathrm{~m}$ above mean high water and in areas not experiencing strong erosional trends. Survival to 10 weeks for transplants ranged from $33-100 \%$ at CAHA. Plants placed below the specified elevation range grew larger than plants placed above the range, likely due to greater availability of water and nutrients. However, their probability of survival can be low due to the higher risk of overwash. Plants placed above the specified elevation range were found to be limited in size due to water/nutrient availability and biotic factors such as increased competition and herbivory.

Johnson (2004) and Jolls, written commun. (2005) report on a growth chamber experiment that evaluated the competitive effects of perennial plant neighbors (Cakile edentula, Iva imbricata and Uniola paniculata). A. pumilis plants experienced reduced survival and growth with these other plants and reduced growth when grown with other A. pumilis plants. Association with other A. pumilis plants is less detrimental than with the other species in term of survival, plant diameter, total competitive response and relative growth rate, although the limiting resources and mechanisms remain unknown. According to the authors: "Reduced performance of Amaranthus planted with neighbors in this experiment suggests that this species is a relatively poor competitor and may suffer lower reproductive fitness from competitive interactions with associates on the beach." The specific mechanisms of competition were not investigated but are cited as a future research need, particularly the abiotic resource partitioning (Hutchinson, 1961) and the relative effects of biotic and abiotic factors among the associate species in the dune community.

\section{Threats to Reproduction and Survival}

The predominant threat to A. pumilis is loss of suitable habitat, primarily due to beach stabilization efforts and storm-related erosion (USFWS, 1993). This species occupies a narrow and precarious elevation niche, bounded by its relative intolerance of flooding in lower beach settings and competition with other plants in upper beach and dune settings. Its placement within upper beach and overwash area habitats is severely limiting because these areas are often absent on barrier islands that are experiencing beach erosion. If sea levels continue to rise then beach erosion and habitat loss will accelerate, especially where beach stabilization efforts limit the ability of barrier islands to respond naturally to such changes (USFWS, 1993).

Previous surveys have found very few A. pumilis plants on east- and north-east facing coastlines, which experience the greatest erosion rates. South-facing beaches, such as those immediately south of Cape Hatteras, have lower erosion rates and likely provide better habitat for A. pumilis. Construction and maintenance of a continuous barrier dune by the North Carolina Department of Transportation to protect Route 12 is likely also a significant factor.

Intensive recreational use, both vehicular and pedestrian, also threatens the plant's survival. Its stems are easily broken or crushed by foot traffic and tires, thus, even minor traffic can be detrimental during the growing season (USFWS, 1993). Although some may argue that recreational uses in the dormant season may even be helpful by decreasing and/or limiting the cover of perennial vegetation, there are no data to support this premise and heavy traffic can erode substrates and pulverize or bury seeds below depths from which seeds can germinate. Particularly in the Carolinas, webworms (caterpillars) can defoliate the plants to the point of killing them or at least preventing reproductive functions.

The U.S. Fish and Wildlife Service (1996) Recovery Plan includes the following additional relevant information regarding threats to this species' reproduction and survival:

"Habitat loss and degradation due to shoreline development and beach stabilization and intensive use by off-road vehicles during reproductive seasons has contributed to the decline of each of these listed species... Although management of the ecosystem as a whole is always the preferable approach and is the ultimate recommendation of this plan, as well as of the recovery plans for the other federally listed species, in some cases single-species management actions are necessary and appropriate. The proposed reintroduction of seabeach amaranth to habitat from which it has disappeared all along the Atlantic Coast is another such species-specific action that is being recommended.

At island ends, inlet migration generally means that land is accreting on one side of the inlet and eroding on the other. On the eroding side of the inlet, habitat for seabeach amaranth is usually small or absent. 
Accreting sides of inlets are, along with accreting capes, the most favorable habitat for the plant. Since most of the beaches in the Carolinas are eroding, upper beach habitat for seabeach amaranth is generally poor. The near absence of seabeach amaranth from North Carolina north of Cape Hatteras is related to this fact. North of Cape Hatteras there are $165 \mathrm{~km}$ of beach (nearly all of it strongly eroding) with only a single inlet (Oregon Inlet). In both 1987 and 1988, only two individuals were found in this stretch, and one of those was found in a casual or adventive site on a sound-side beach back of Avon.

Local exceptions to beach erosion can be found in the Carolinas, such as in Brunswick County, North Carolina, on the west end of Holden Beach, where beach accretion has led to a thriving population on the upper beach. Brunswick County has been a stronghold for seabeach amaranth throughout the 1980s, with populations (some of them large) on nearly every barrier island. Reasons for the health of these populations are the localized accretion of beaches, frequency of inlets, and absence of erosion-control structures. Human recreational use of the beach habitats favored by seabeach amaranth is, of course, extensive, and sometimes intensive, especially on Long Island, New York. From the point of view of seabeach amaranth, this use can be divided simply into two categories - vehicular and pedestrian. Many beaches in the Carolinas and New York allow off-road-vehicle (ORV) traffic, at least during some seasons. On some beaches, traffic is relatively light, whereas on others it can approach traffic jam proportions. In general, ORV traffic occurring during seabeach amaranth's dormant season could potentially have some negative impacts, including the pulverization of seeds. At levels of ORV use generally found on Carolina beaches, there is little evidence of highly detrimental effects, unless it results in massive physical erosion or degradation of the site, such as can be seen at the northern end of Carolina Beach. In some cases, off-season ORV traffic may even provide some benefits for seabeach amaranth. This appears to be true at Cape Hatteras, where a large sand flat would probably proceed through succession into dominance by perennial grasses and shrubs except for heavy winter truck traffic by fishermen. In spring and summer much of the area is fenced off from traffic by the National Park Service in order to protect nesting habitat for least terns, piping plovers, and other shorebirds. Following nesting, in early fall, fencing is removed to allow truck traffic. Physical disturbance by trucks helps prevent the widespread establishment of perennials, which would render the area unsuitable as a nesting ground for birds and as unsuitable habitat for seabeach amaranth.

While seabeach amaranth populations are somewhat tolerant of ORV use from December until May, the brittle, fleshy stems are easily broken, and growing plants (May to December) do not generally survive a single pass by a truck tire. Thus, even minor beach traffic directly across the plants during the growing season is detrimental, causing mortality and reduced seed production. In the Carolinas, traffic has been successfully routed around these sensitive areas, and most ORV drivers have been respectful of the public land that has been roped off for nesting birds or seabeach amaranth. The seabeach amaranth and nesting shorebirds often occur together in the Carolinas, even outside roped-off areas. On New York's heavily used beaches, however, the interiors of shorebird exclosures are often the only places where seabeach amaranth is found, strongly suggesting that heavy ORV traffic and beach grooming are rendering most of the beaches unsuitable there (DuBois, personal communication, 1995).

Pedestrian traffic during the dormant season (December to May) is unlikely to have any significant effects in the Carolinas. Even during the growing season pedestrian traffic there generally has little effect on populations of seabeach amaranth. Many beaches with daily use by thousands of sunbathers, joggers, and other recreation enthusiasts have substantial and apparently healthy populations of seabeach amaranth. The main exceptions appear to be in the vicinity of high-rise hotels or condominiums, where beach usage is concentrated and portions of seabeach amaranth populations are sometimes eliminated or reduced by repeated trampling. The general compatibility of human pedestrian recreation enthusiasts and seabeach amaranth lies in their preferences for different parts of the beach. Joggers inevitably prefer packed sand and stay seaward of seabeach amaranth. The great majority of sunbathers prefer to be close to the water and away from beach vegetation, so they generally choose sites seaward of those favored by seabeach amaranth. Island-end flats, the sites most favored by seabeach amaranth, are generally not found desirable by beach-goers, except as a destination to be reached in a long stroll. On the rare beaches where proximity to hotels or condominiums brings heavier use to island-end flats, Bucher and Weakley (1990) saw further evidence of humans avoiding seabeach amaranth habitat. Frequently a low ridge of loose sand, often much favored by seabeach amaranth, parallels the shoreline as it hooks back toward the inlet; joggers, strollers, and birdwatchers stay on the packed sand in front of this ridge, while sunbathers occupy locations in front of or behind it. 
Beach replenishment — On the other hand, beach replenishment rebuilds habitat for seabeach amaranth and can have long-term benefits. For instance, Wrightsville Beach was probably the first location in North Carolina where seabeach amaranth was collected, in 1888. It was collected several times later, such as in 1931. A beach replenishment project was begun on Wrightsville Beach in 1965 by the U.S. Army Corps of Engineers (Corps). A jetty was constructed on the south end of Wrightsville Beach in 1966, and the beach was "rebuilt" with sand (all placement of sand was on the north and central portions of the island) (Tom Jarrett, Corps, Wilmington District, personal communication, 1989). Additional renourishment was undertaken in 1970, but then a lapse of 10 years occurred and severe erosion took place. The full length of the beach was surveyed on a regular basis during 1978 to 1980; no seabeach amaranth was found. In 1980 and 1981, a total of 1.7 million cubic yards of sand was placed on the beach. Eighty-five seabeach amaranth plants were found on the north end in 1985 and twelve plants were found on the south end. A further renourishment of 900,000 cubic yards was placed in 1986. That same year, 611 plants were found on the north end (the south end was not surveyed). In 1987, the censuses recorded 431 individuals on the north end and 69 on the south, and in 1988, the north end had 2,521, and the south had 414. Overall, Wrightsville Beach is now one of the largest and least variable populations of seabeach amaranth known. It has apparently reestablished itself (whether from a seedbank or from colonization is not known) on this renourished beach. It is interesting that on the south end, which accreted because of the jetty, a population has also become reestablished, though consistently smaller than on the renourished north end.

At Atlantic Beach, dredge spoil placement has also apparently aided in the reestablishment of a population of seabeach amaranth. A very large renourishment project at Carolina Beach, North Carolina, however, has failed to help seabeach amaranth. A few plants are present, but it is one of the poorest populations in the State, despite repeated renourishment since the 1960s. Reasons include the use of a 2,000-foot-long rock wall and heavy ORV use during the growing season.

Habitat loss and degradation are, by far, the greatest threats to the continued existence of seabeach amaranth. However, on a more local scale, predation (herbivory) by webworms (the caterpillars of small moths) is a major source of mortality and lowered fecundity in the Carolinas... Potential webworm herbivory would seem to be greater in the South, so it seems unlikely that herbivory is the cause of the extirpation of seabeach amaranth in the North. Not only are there more potential species of webworm in the South, but also they are likely to produce more broods over the course of a longer warm season... Webworms appear to have strong effects on seabeach amaranth. Most populations experienced moderate to severe herbivory by webworms in both 1987 and 1988."

It is noted that if control measures against webworms are needed, BT (Bacillus thuringensis), which affect lepidopterans, could be detrimental to important and beneficial moths and butterflies, including a rare skipper butterfly that occurs on Bogue Banks, NC (Atlantic Beach to Emerald Isle) and parts of Cape Lookout National Seashore (Shackleford Banks). This skipper (Atrytonopsis sp.) has not been named yet, but is considered to be very rare and limited to the sand dunes in this central part of the North Carolina coast.

\section{Adaptive Resource Management}

Adaptive Resource Management (ARM) is an approach of prepared responsiveness, whereby policy and management actions are integrated with feedback systems based on monitoring and evaluation (Holling, 1978; Lessard, 1998; Bellamy and others, 2001). ARM is an iterative process that integrates planning and management decisions with research and monitoring to improve management in achieving management goals and objectives. Implicit is the notion that management policies are implemented as experiments evaluated to yield new knowledge and progress in achieving management objectives. Land managers implement policies and adjust prescriptions based on knowledge gained from periodic monitoring efforts. 


\section{Framework for ARM}

\section{A. Questions to be Addressed}

1. What is the location and abundance of $A$. pumilis plants within CAHA?

2. How consistently does A. pumilis occur in areas of suitable habitat within CAHA? How consistent are A. pumilis population levels?

3. What factors limit germination and survival to reproductive maturity, including the production and success of seed banks.

\section{B. Proposed ARM Experiment}

Effects of human disturbance (Item 1.C above) - The principal human disturbance affecting A. pumilis is ORV and pedestrian traffic. Both can easily crush and/or kill A. pumilis plants and have the potential to disturb substrates and deeply bury seeds during the off-season (which prevents subsequent germination). A null hypothesis for investigating this issue is that human disturbance frequency and intensity has no effect on $A$. pumilis germination and survival to reproductive maturity. A research design involving the experimental application of differing levels of wheeled or foot traffic to randomly assigned vegetative plots is the best method for evaluating the crushing resistance and tolerance of common plant species and communities (Marion and Cole, 1996). For obvious reasons such a design would be inappropriate for naturally-occurring individuals of any rare species. However, it should be possible to identify areas of equivalent $A$. pumilis habitat that are: 1) closed to human use, 2) open to use but receiving low use, and 3) open to use but receiving high use. It may even be possible to identify areas that receive differing levels of exclusive use by either pedestrian or ORV traffic. A before-and-after design is also possible if areas of the beach are closed to ORV traffic for a period (e.g., the completion of nesting by rare bird species) and then opened to traffic. If study areas have insufficient numbers of native plants it may be possible to place greenhouse-cultivated plants as was done in earlier CAHA studies (Sellars, 2001; Sellars and Jolls, 2001).

Ideally, such a study should be conducted in July-September when A. pumilis plants are sufficiently large to locate and evaluate for damage. Documentation of the type, numbers, duration, and locations of ORV and pedestrian visitation within the study sites can be conducted with either direct observation or cameras set up with timers on a sample of weekday and weekend days. Weekly surveys to assess the number, location, and condition (plant diameter, $\mathrm{mm}$ ) of all A. pumilis plants would be conducted to evaluate human disturbance effects.

\section{Research Needs}

A. pumilis is inherently difficult to investigate and manage because it is both temporally and spatially dynamic. Management is also challenging due to the paucity of research documenting the relative importance of various factors affecting A. pumilis germination and survival. Some primary factors noted in the existing literature include presence of an adequate seed bank, seed depth in substrate, availability of suitable habitat, competition with other plants, effects of overwash events, webworm herbivory, and human disturbance. It is likely that the relative importance of these factors vary from one location to another so research within CAHA is vital to resource protection decisions. A number of studies have examined issues related to habitat suitability (Sellars, 2001; Sellars and Jolls, 2001; Sellars and others, 2003; Jolls and others, 2004), plant germination (Blazich and others, 2005; Jolls and others, 2001), and the effect of competition with other plants (Jolls, written commun., 2005). However, a comprehensive program of basic research on A. pumilis that seeks to integrate existing knowledge, explore gaps in knowledge, and examine the relative importance of influential factors is needed.

Factors Limiting Seed and Seedling Success (Item 1.A.3. above)—Such research might begin with survivorship studies on seedlings found or planted on CAHA beaches. Such work could identify the most critical phase of the species life-history and limiting factors. This could be complemented with studies that examine natural seed storage, viability and long distance transport. The effects of off-season pedestrian and ORV 
traffic on A. pumilis seeds, including potential damage and depth of burial, is another important research topic. It is unclear what effects off-season human uses have on the integrity of $A$. pumilis seeds and depth of burial. Finally, there is evidence that freshwater may play an important role in this species germination and growth. Investigation of this linkage can help determine whether the species is a true halophyte or whether it simply seeks out non-competitive environments characterized by higher salt concentrations. Additional research needs include the impact of beach stabilization and/or "nourishment", including descriptive work documenting populations sizes relative to sites which have or have not been impacted.

\section{Habitat Management Recommendations}

\section{A. Current management}

No active management for amaranth occurred in 2005. Monitoring surveys are incomplete (as of 8/30/05) but one plant was located in the Bodie Island flats. Resource closures for birds were established when nesting occurred or was expected at Hatteras Island, Bodie Island, Green Island, Cape Point and South Ocracoke; thus, where A. pumilis might have occurred, the plant benefited from the bird protection enacted. Likely areas where A. pumilis may have germinated include the inlet-pond area at Bodie Spit, Cape Point, and South Ocracoke. In the past when A. pumilis is found outside of areas closed for bird protection, or in the Fall, park staff have either fenced off an area of approximately $10 \mathrm{~m}$ in diameter or placed one of the bird nest protection cages over the plant with appropriate signs asking visitors to stay clear of the location. These protection measures are continued until the plants have died, occasionally as late as December.

\section{B. Management Options}

\section{Option A: Highest Degree of Protection}

\section{Recommendations:}

1. Completely close all potential A. pumilis habitat (as defined by historic and extant populations within the last 10 years) at CAHA to all recreational activities year round. It is acknowledged that this species has substantial overlap with the habitats of rare bird species (e.g., Piping Plover \& American Oystercatcher) and that habitat protection for these species will also benefit $A$. pumilis populations. During August, efforts should be directed to carefully monitor A. pumilis plants at all sites where it has been noted in the past decade or in any new suitable habitats.

2. Essential vehicles (law enforcement, NPS personnel, approved researchers) should only enter restricted areas subject to the guidelines in the Essential Vehicles section of Appendix G of the Revised Recovery Plan for the piping plover (USFWS, 1996). Vehicles should not exceed $10 \mathrm{mph}$.

3. Locate and eliminate all individuals of beach vitex (Vitex rotundifolia), a recent invasive beach plant from South and North Carolina. This species grows in similar habitats and outcompetes A. pumilis, thus is a threat to coastal dune habitats.

\section{Predicted effects:}

There should be no direct recreational impacts on any A. pumilis plants within the boundaries of CAHA, and no impact on their habitats under this management regime. There remains a small probability of Essential Vehicle impact on plants and seeds due to crushing and burial, respectively.

\section{Option B: Moderate Protection}

\section{Recommendations:}

1. Completely close all potential A. pumilis habitat (as defined by historic and extant populations within the last 10 years) at CAHA to ORV traffic and boat landings from April 15 until November 30. This could include areas on Bodie Island Spit, Green Island, Hatteras Island, including Cape Point, South 
Beach, and Hatteras Spit, and Ocracoke Island, including North Ocracoke (inlet area), and South Ocracoke.

2. At the seven sites mentioned above, pedestrians should be allowed within a 50 -m corridor (ca. $150 \mathrm{ft}$ ) from the high tide line landward, from sunrise to sunset. At areas of CAHA outside of the seven focal areas, monitoring for $A$. pumilis should be conducted during August (see Monitoring section below). Where plants are found, resource closures (10-m diameter) with signs should be erected to protect each plant.

3. Interpretive signs about the trampling susceptibility of A. pumilis should be placed at all ORV entry points to CAHA, at all boat ramps and marinas, and at Park kiosks.

4. Same as Option A, \# 2 and 3 above.

\section{Predicted effects:}

There may be limited mortality to plants and burial of seeds caused by ORVs within the 50-m zone. The risks of mortality to plants and seeds in areas outside of the focal sites, however, is higher. Potential negative effects of Essential Vehicle use (ORV use by NPS staff, monitoring personnel, trappers) are the same as in Option A. Chances of spreading beach vitex is higher than under Option A.

\section{Option C: Minimum Protection}

\section{Recommendations:}

1. Restrict all ORV and pedestrian recreation to a corridor within $50 \mathrm{~m}$ (ca. $150 \mathrm{ft}$ ) of the oceanside mean high tide line from sunrise to sunset, at all potential A. pumilis habitat (as defined by historic and extant populations within the last 10 years) from April 15 to November 30. This includes the seven sites referred to in Option B \# 1 above. In August, monitor the areas for A. pumilis plants as prescribed below. Vehicle speed should not exceed $10 \mathrm{mph}$.

2. Enact recommendations for Option A \# 2-4 above.

\section{Predicted effects:}

Plants and seeds are placed at risk by pedestrians and recreational ORVs and boats at the focal sites and all other areas. Adult plants may be crushed and seeds buried. Enforcement requirements are higher under this option than under options A or B, thus increasing the probability of harm to plants. Effects outside of the seven focal areas and potential effects of Essential Vehicle use, and ORV monitoring are the same as under Options A and B. Chances of having beach vitex spread is enhanced with more vehicle access.

\section{Monitoring Protocols}

\section{A. Monitoring}

Thorough surveys to locate and count all A. pumilis plants should be conducted annually in early August in all areas of potential habitat to track plant numbers and distribution and to identify areas for closure. The location of all individual plants or plant clusters should be recorded with a GPS device with sub-meter accuracy. The diameter $(\mathrm{mm})$ of each plant should be recorded and whether it is located in an area open or closed to pedestrian and/or ORV traffic. Any evidence of these uses (e.g., footprints or tire tracks) within 20 feet should also be recorded. A follow-up monitoring survey in late September is also recommended to examine survivorship and seed production. This survey should focus on finding new plants and relocating previously surveyed plants to evaluate survivorship and plant diameter growth. It is also recommended that some experimental surveys be conducted in May to see if seedling or juvenile plants can be identified and to ensure their protection. 


\section{Reporting Procedures}

\section{A. Reporting}

Field data should be recorded on field forms developed in conjunction with other partner agencies, scientists and managers. GPS data should be downloaded to CAHA computers, error checked, post processed and made available to partners and scientists. Field forms should be quality checked by an independent examiner and data electronically entered, analyzed where needed, summarized in reports in text, tabular and graphic form, and submitted to both CAHA management personnel and other cooperating agency personnel and other scientists and managers as requested. Reports should be available both in electronic form (pdf preferred) and in limited numbers of hard copy.

\section{Data Management}

\section{A. Raw Data Collection}

Field data sheets should include, at a minimum, the date, the reference location (GPS and usually a code number), a point or specific area, and observer name or initials. Because of the large amount of data included in these different data collection efforts, we strongly urge that all individuals engaged in data collection be trained in advance of the actual data collection period. Regardless of how clear a field form appears to be, questions always arise about how to record certain types of data. Such training should include the identification of seedling, juvenile, flowering and fruiting plants and the use of GPS devices.

\section{B. Data Entry}

Because the National Park Service (as well as other agencies) has determined that Microsoft Access will be the official database management software in the monitoring programs, we recommend it as the primary management tool. In some cases, Excel spreadsheets may be used since this is what the cooperators/contractors often provide. However, conversion of Excel to Access is not difficult and the structure of the tables is quite similar.

Quality assurance and quality control are best maintained by having the field data reviewed and entered into the database on the same day it is collected. Two individuals should first review the data to reduce error propagation. Generally it is best to have the person collecting the data also doing the data entry, followed by having a second person compare the computer printout with the original field sheets. This second step can be done at a later date to reduce fatigue on field days.

\section{Data Storage}

Field data sheets should be stored in a safe, low-fire-risk location in or near the NPS Headquarters in Manteo. Upon entry into a PC's electronic Access database, an extra copy of the database should be generated on a separate portable hard drive, or on CDs which then should be maintained in a separate building. If a computer network is available at the site, the files can be more easily transferred electronically to other PC sites, rather than having to physically transfer media between locations. Security demands by the NPS may require extra steps in the data management outlined here.

\section{Data Analysis Techniques}

The methods for analyzing the data will vary greatly depending upon the question and the level of analysis of interest. Excellent statistical support and advice is available both at the USGS Patuxent Wildlife Research Center (Drs. Jim Nichols, James Hines, John Sauer, William Kendall, Michael Runge, and Jeff Hatfield) or from universities. Biologists at CAHA should consult with one or more statisticians whenever statistical analyses are to be conducted. 


\section{Acknowledgments}

The author would like to acknowledge the input of beneficial scientific and technical reviews received from Dr. Claudia L. Jolls, Associate Professor, Department of Biology, East Carolina University and Dale Suiter, Endangered Species Biologist, U.S. Fish and Wildlife Service. Administrative review was also provided by the following NPS personnel: Sherri Fields and Steve Harrison, and by Dr. J.B. French, USGS Patuxent Wildlife Research Center.

The USGS Patuxent Wildlife Research Center developed these protocols, based on the best available scientific information, to guide management, monitoring and research activity at CAHA that would result in the protection and recovery of each species. These protocols do not attempt to balance the need for protection of these species with other activities that occur at CAHA, nor was NPS management policy considered in detail. A draft of the protocols was sent to species experts for scientific review; the final draft of protocols were reviewed by NPS personnel to ensure that description of recent management at CAHA was accurately represented and that the approach was consistent with our work agreement.

\section{Selected References}

Baskin, J.M., and Baskin, C.C., 1998, Seed dormancy and germination in the rare plant species Amaranthus pumilus: Castanea, v. 63, p. 493-494.

Bellamy, J.A., Walker, D.H., McDonald, G.T., and Syme, G.J., 2001, A systems approach to the evaluation of natural resource management initiatives: Journal of Environmental Management, v. 63, p. 407-423.

Blazich, F.A., Warren, S.L., Nash, D.L., and Reece, W.M., 2005, Seed germination of Seabeach Amaranth (Amaranthus pumilis) as influenced by stratification, temperature, and light: Journal of Environmental Horticulture, v. 23, no. 1, p. 33-36.

Bucher, M., and Weakley, A., 1990, Status survey of seabeach amaranth (Amaranthus pumilus Rafinesque) in North and South Carolina: Report to North Carolina Plant Conservation Program, North Carolina Department of Agriculture, Raleigh, North Carolina, and Asheville Field Office, U.S. Fish and Wildlife Service, Asheville, North Carolina. 149 p .

Christensen, N., 1988, Vegetation of the southeastern Coastal Plain in Barbour, M.G., and Billings, W.D., eds., North American terrestrial vegetation: Cambridge, Massachusetts, Cambridge University Press, p. 317-363.

Dolan, R., and Lins, H., 1987, Beaches and barrier islands: Scientific American, v. 255, no. 7, p. 68-77.

Hancock, T.E., and Hosier, P.E., 2003, Ecology of the threatened species Amaranthus pumilus Rafinesque: Castanea, v. 68 , no. 3, p. 236-244.

Holling, C.S., ed., 1978, Adaptive environmental assessment and management: New York, John Wiley \& Sons, $377 \mathrm{p}$.

Hutchinson, G.E., 1961, The paradox of the plankton: American Naturalist, v. 95, p. 137-145.

Johnson, S.E., 2004, An assessment of the nearest associated and the effects of competition on the threatened dune annual, Amaranthus pumilus Rafinesque (Amaranthaceae): Greenville, North Carolina, East Carolina University, Department of Biology, M.S. Thesis, 98 p.

Jolls, C.L., Cooley, A., and Sellars, J.D., 2001, Germination ecology of seabeach amaranth, Amaranthus pumilus, in controlled environments: Southeastern Biology, v. 48, p. 169.

Jolls, C.L., Sellars, J.D., and Wigent, C.A., 2004, Restore Seabeach Amaranth; A Federally threatened species; habitat assessment and restoration of Amaranthus pumilus, (Amaranthaceae) using remote sensing data: 2001 Natural Resource Presentation Program, RMP Project Statement CAHA-N-018.000, National Park Service, Final Report, 144 p. 
Lessard, G., 1998, An adaptive approach to planning and decision-making: Landscape and Urban Planning, v. 40 , nos. $1-3$, p. $81-87$.

Mangels, C., 1991, Seabeach amaranth in New York State: New York Flora Association Newsletter, v. 2, no. 2, p. 7-8.

Marion, J.L., and Cole, D.N., 1996, Spatial and temporal variation in soil and vegetation impacts on campsites: Delaware Water Gap National Recreation Area: Ecological Applications, v. 6, no. 2, p. 520-530.

NatureServe, 2005, NatureServe Explorer: An online encyclopedia of life, version 7.1, NatureServe,

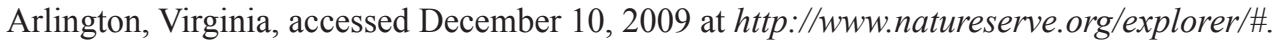

New Jersey Department of Environmental Protection, 2003,Sea Beach Amaranth, Endangered Plants of New Jersey Fact Sheet: Trenton, New Jersey, Office of Land Management, http://www.fws.gov/northeast/nyfo/es/ amaranthweb/fact_sheets/NJ.pdf, 2p.

Schafale, M.P., and Weakley, A.S., 1990, Classification of the natural communities of North Carolina, third approximation: Raleigh, North Carolina, North Carolina Natural Heritage Program, 321 p., accessed December 10, 2009 at http://www.ncnhp.org/Images/Other\%20Publications/class.pdf.

Sellars, J.D., 2001, Habitat assessment and restoration methodologies for the seabeach amaranth (Amaranthus pumilus, Rafinesque, Amaranthaceae): Greenville, North Carolina, East Carolina University, M.S. Thesis, $94 \mathrm{p}$.

Sellars, J.D., and Jolls, C.L., 2001, Critical knowledge for the restoration of seabeach amaranth, Amaranthus pumilus: Bulletin of the Association of Southeastern Biologists, v. 48, no. 2, p. 149.

Sellars, J.D., Jolls, C.L., and Wigent, C.A., 2003, Success of Seabeach Amaranth (Amaranthus pumilus Raf.) using habitat selection based on Light Detection and Ranging (LIDAR) data, in Proceedings of the 3rd Biennial Coastal Geo Tools Conference, Charleston, South Carolina, January 6-9, 2003, http://www.csc. noaa.gov/geotools/proceedings/pdf_files/ps_abs/jollsc.pdf.

U.S. Fish and Wildlife Service, 1993, Endangered and threatened wildlife and plants; determination of seabeach amaranth (Amaranthus pumilus) to a threatened species: Federal Register 58(65), p. 18,035-18,042.

U.S. Fish and Wildlife Service, 1996, Recovery plan for Seabeach Amaranthus (Amaranthus pumilus): Atlanta, Georgia, U.S. Fish and Wildlife Service, Southeast Region, 59 p.

Weakley, A., and Bucher, M., 1991, Status survey of seabeach amaranth (Amaranthus pumilus Rafinesque) in North and South Carolina, 2d ed. (after Hurricane Hugo): Report to North Carolina Plant Conservation Program, North Carolina Department of Agriculture, Raleigh, North Carolina, and Asheville Field Office, U.S. Fish and Wildlife Service, Asheville, North Carolina, 149 p . 
Prepared by USGS West Trenton Publishing Service Center. Editorial assistance by Ruth M. Larkins and Valerie M. Gaine. Graphics and layout by Timothy W. Auer.

For additional information, contact:

Director, Patuxent Wildlife Research Center (PWRC)

U.S. Geological Survey

12100 Beech Forest Road

Laurel, MD 20708

or visit the PWRC Web site at: http://www.pwrc.usgs.gov 


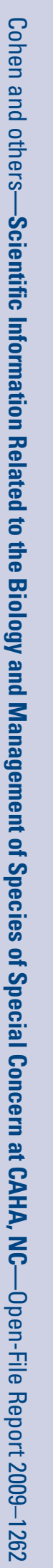

9 Printed on recycled paper 